\section{Iry

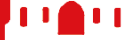

US Army Corps

of Engineers ${ }_{\circledast}$

Engineer Research and

Development Center

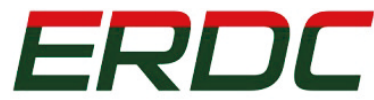

INNOVATIVE SOLUTIONS

for a safer, better world

Rapid Airfield Damage Recovery (RADR)

\title{
Wet Weather Crater Repair Technologies for Grooved and Smooth Pavements
}

Haley P. Bell, Cecilia L. Dean, and Craig A. Rutland

April 2018

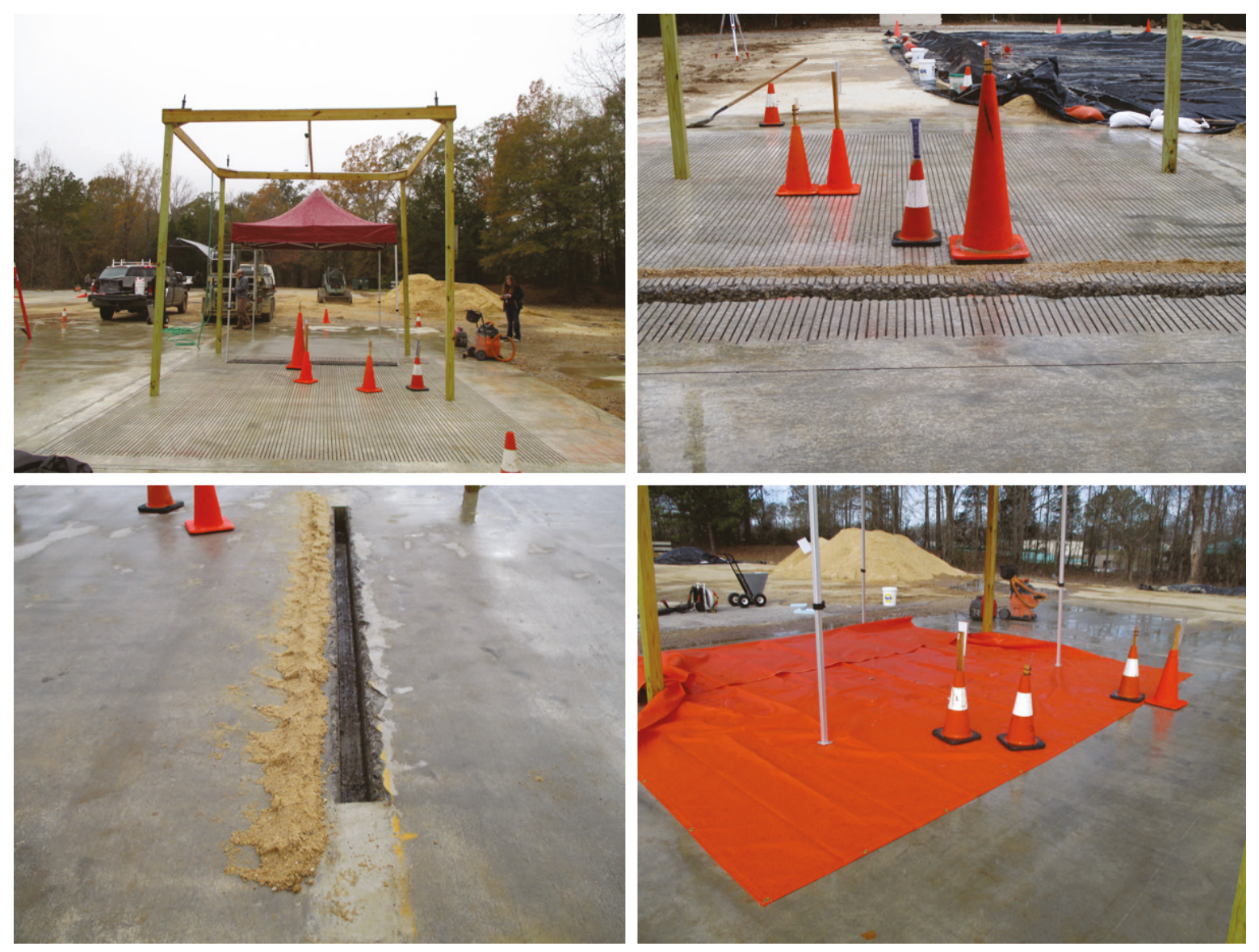


The U.S. Army Engineer Research and Development Center (ERDC) solves the nation's toughest engineering and environmental challenges. ERDC develops innovative solutions in civil and military engineering, geospatial sciences, water resources, and environmental sciences for the Army, the Department of Defense, civilian agencies, and our nation's public good. Find out more at www.erdc.usace.army.mil.

To search for other technical reports published by ERDC, visit the ERDC online library at http://acwc.sdp.sirsi.net/client/default. 


\section{Wet Weather Crater Repair Methods for Grooved and Smooth Pavements}

Haley P. Bell and Cecilia L. Dean

Geotechnical and Structures Laboratory

U.S. Army Engineer Research and Development Center

3909 Halls Ferry Road

Vicksburg, MS 39180-6199

Craig A. Rutland

Civil Engineering Branch, Engineering Division

Air Force Civil Engineer Center

139 Barnes Drive, Suite 1

Tyndall Air Force Base, FL 32403-5319

Final report

Approved for public release; distribution is unlimited.

Prepared for Headquarters, Air Force Civil Engineer Center

Tyndall Air Force Base, FL 32403-5319

Under Project Number 457442 


\section{Abstract}

A research study was conducted at the U.S. Army Engineer Research and Development Center (ERDC) in Vicksburg, MS, to evaluate methods for preventing rainfall runoff from entering open bomb craters during wet weather repairs. The study evaluated the use of seven commercial off-theshelf barriers on both smooth and grooved concrete pavements. Water runoff, particularly in grooved concrete pavements, is one of the greatest challenges for repairing craters in wet weather. Also included in the evaluation was a heavy duty pop-up tent placed over the open repair area. This report presents the technical evaluation of the various water barriers and the pop-up tent using simulated rainfall of approximately $1 \mathrm{in} . / \mathrm{hr}$. Results indicate that, along with a pop-up tent, a 6-in.-wide berm of compacted sand is the most effective barrier for grooved and smooth pavements. A polyvinyl tarp is also effective for smooth pavements. A sand berm, polyvinyl tarp, and a pop-up tent are recommended for use as supplemental items by crater repair teams during times of wet weather.

DISCLAIMER: The contents of this report are not to be used for advertising, publication, or promotional purposes. Citation of trade names does not constitute an official endorsement or approval of the use of such commercial products. All product names and trademarks cited are the property of their respective owners. The findings of this report are not to be construed as an official Department of the Army position unless so designated by other authorized documents. 


\section{Contents}

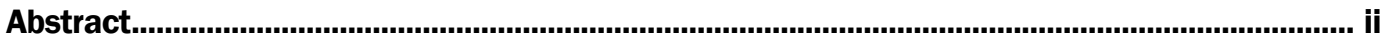

Figures and Tables....................................................................................................................................

Preface ................................................................................................................................................ vii

Unit Conversion Factors.................................................................................................................... viii

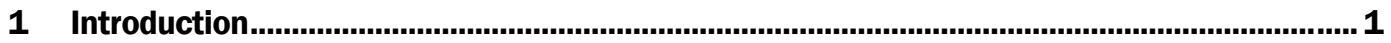

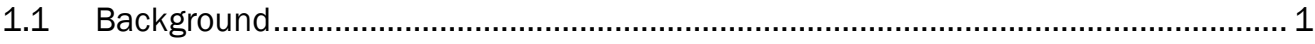

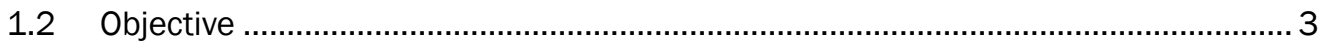

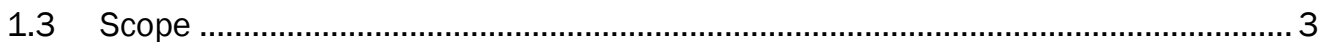

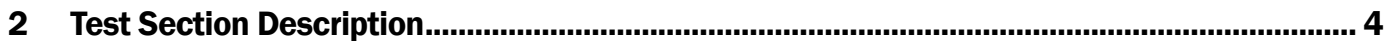

2.1 PCC test section construction ................................................................................ 4

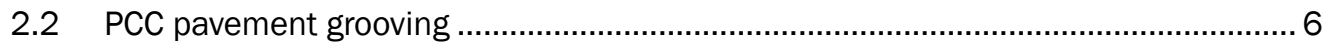

2.3 PCC rainwater catch basin ........................................................................ 10

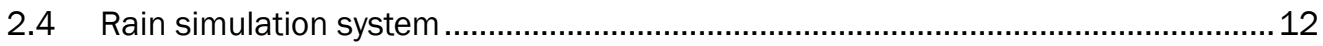

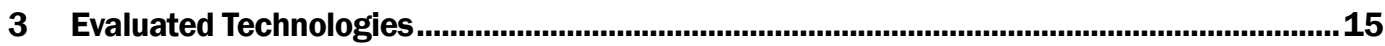

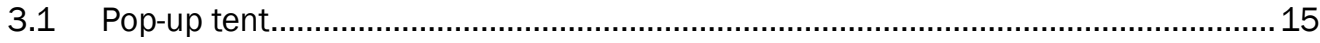

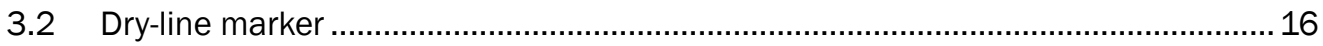

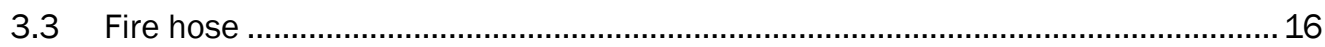

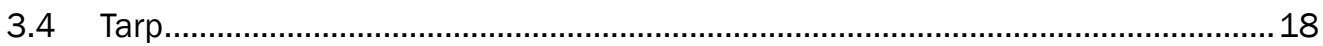

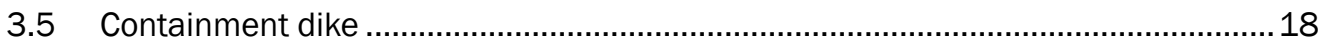

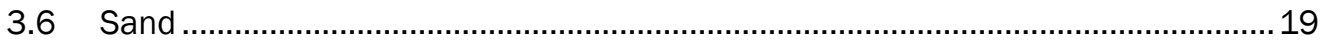

3.7 Quick Dam Expanding Barrier............................................................................ 19

4 Field Evaluation and Results................................................................................................ 21

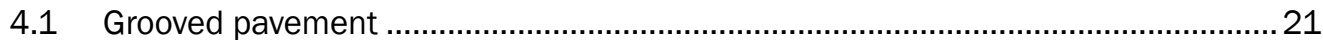

4.1.1 Quick Dam Expanding Barrier - unsaturated .................................................... 23

4.1.2 Quick Dam Expanding Barrier - saturated......................................................... 25

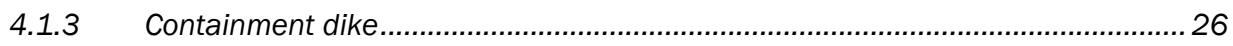

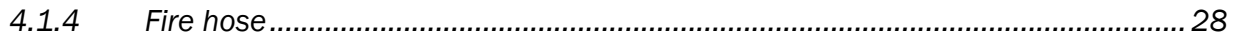

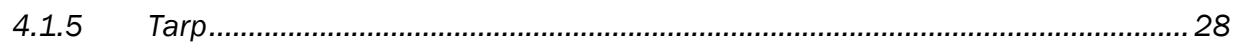

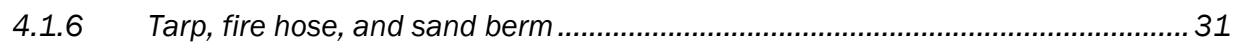

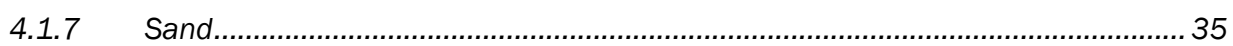

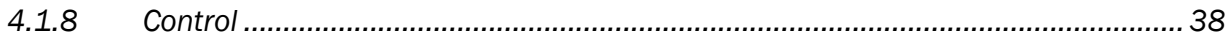

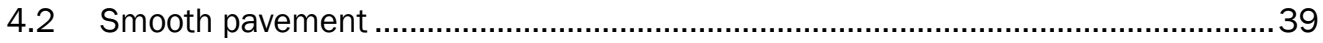

4.2.1 Quick Dam Expanding Barrier - unsaturated .................................................. 40

4.2.2 Quick Dam Expanding Barrier - saturated ...................................................... 41

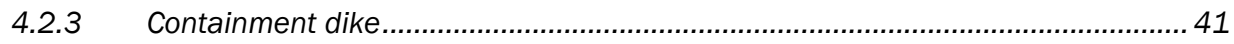

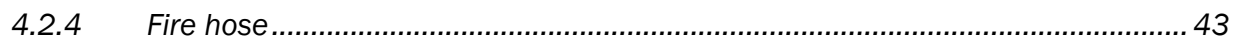

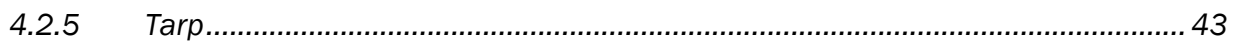

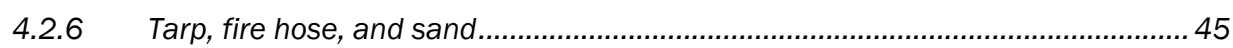




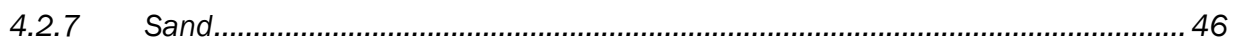

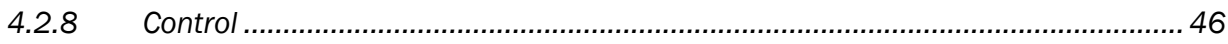

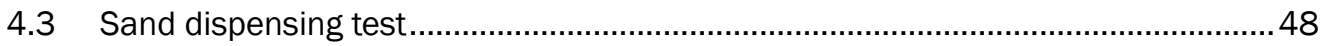

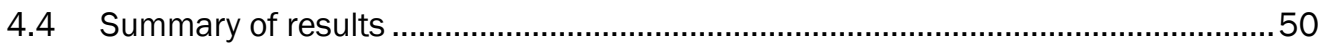

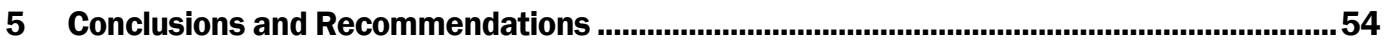

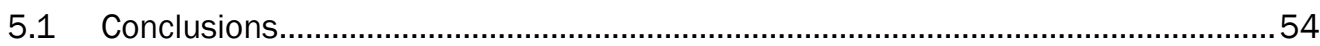

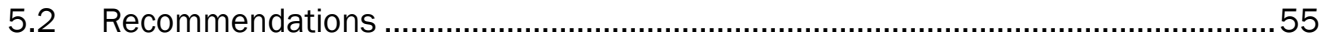

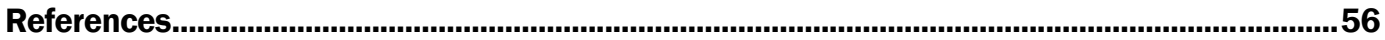

\section{Report Documentation Page}




\section{Figures and Tables}

\section{Figures}

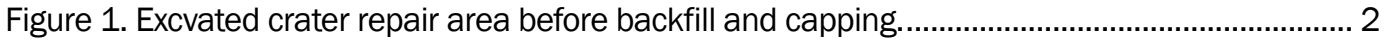

Figure 2. Crater repair capped with rapid-setting concrete............................................................... 2

Figure 3. Plan and profile views of test section................................................................................ 4

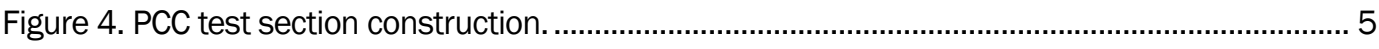

Figure 5. PCC slab before grooving............................................................................................. 7

Figure 6. Measuring the slab for chalked lines before grooving ........................................................ 7

Figure 7. Popping chalked lines for grooving. ……………............................................................ 8

Figure 8. Spraying laquer over chalked lines............................................................................ 8

Figure 9. 20-ft-by-20-ft grooved slab...................................................................................... 9

Figure 10. Grooved PCC pavement....................................................................................... 9

Figure 11. Cutting basin into the grooved slab using a wheel saw................................................. 10

Figure 12. Catch basin cut near low end of grooved slab. ........................................................... 11

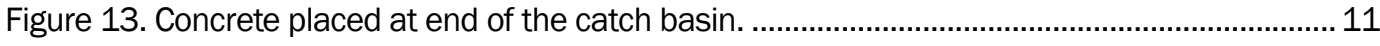

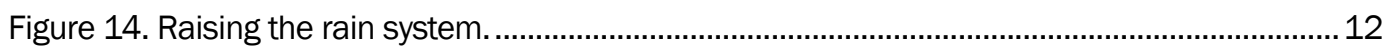

Figure 15. Sprinkler head and hose connection on the rain system............................................ 13

Figure 16. Mounting a rain gauge on the rain system................................................................ 13

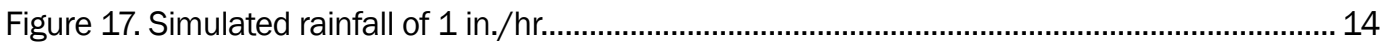

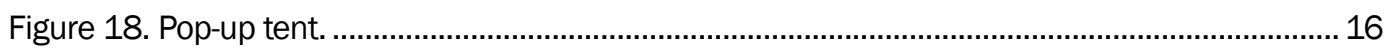

Figure 19. Dry-line marker................................................................................................... 17

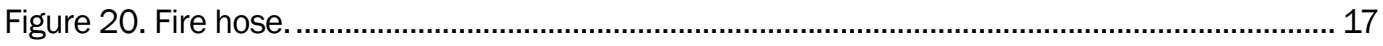

Figure 21. Coated polyvinyl tarp, folded for storage ...................................................................... 18

Figure 22. Containment dike. ................................................................................................. 19

Figure 23. Unsaturated Quick Dam Expanding Barrier. .................................................................. 20

Figure 24. Rain gauges mounted on the rain system and inside cones........................................ 21

Figure 25. Vacuuming water out of the basin. .............................................................................. 22

Figure 26. Blowing water out of pavement grooves between tests.................................................2 23

Figure 27. Unsaturated Quick Dam before evaluation...................................................................... 24

Figure 28. Quick Dam activated in the middle from tent water runoff. ......................................... 24

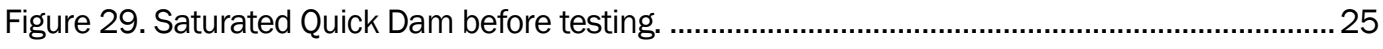

Figure 30. Unsaturated Quick Dam added to north end.............................................................. 26

Figure 31. Containment dikes protecting the basin from rain. ........................................................ 27

Figure 32. Rainwater flowing under the containment dike........................................................ 27

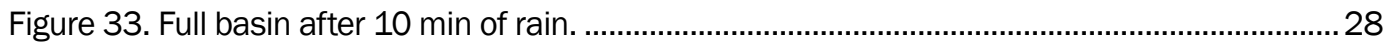

Figure 34. Capped and plugged fire hose partially filled with water. ............................................. 29

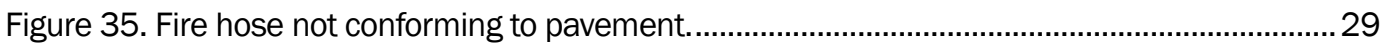

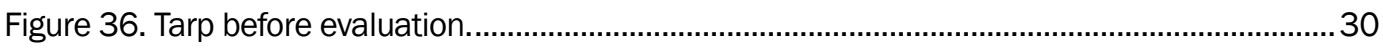


Figure 37. Tent water runoff pooled on top of tarp.................................................................. 30

Figure 38. Placing sand along the edge of the tarp and fire hose.

Figure 39. Compacting sand............................................................................................ 32

Figure 40. Barrier during evaluation.......................................................................................3

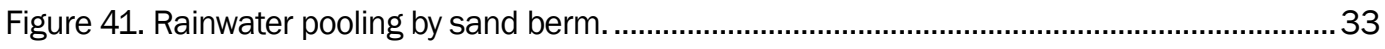

Figure 42. Sand berm remaining after the removal of tarp and fire hose. ....................................34

Figure 43. Measuring water depth in the basin at a quarter point. ...................................................34

Figure 44. Distributing sand onto the grooved pavement..............................................................35

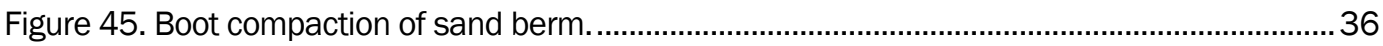

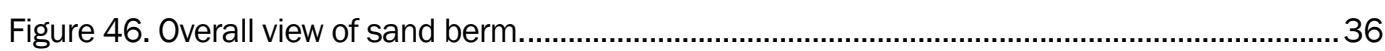

Figure 47. Effect of water runoff from the pop-up tent on the sand barrier...................................... 37

Figure 48. Measuring the depth of collected water in the basin..................................................... 37

Figure 49. Tent water runoff from simulated rain. ...................................................................... 38

Figure 50. Basin filling with rainwater during the control evaluation................................................39

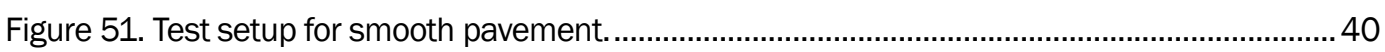

Figure 52. Quick Dam on smooth pavement................................................................................. 41

Figure 53. Saturated Quick Dam on smooth pavement............................................................... 42

Figure 54. Water pooling along the containment dike. ................................................................... 42

Figure 55. Tent water runoff.................................................................................................. 43

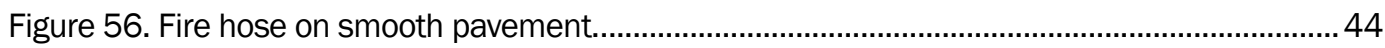

Figure 57. Fire hose water barrier during the smooth pavement test............................................ 44

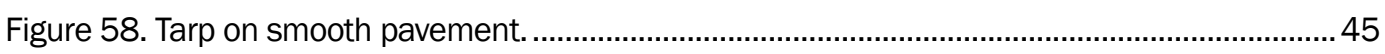

Figure 59. Tarp, fire hose, and sand barrier on smooth pavement............................................... 46

Figure 60. Compacted sand berm on smooth pavement. ............................................................ 47

Figure 61. Sand berm damage from tent water runoff. ................................................................. 47

Figure 62. Using the dry-line marker to deposit sand. .................................................................... 48

Figure 63. Depositing sand out of a 5-gal bucket. ........................................................................ 49

Figure 64. Bucket pour on left; dry-line marker placement on right..................................................49

\section{Tables}

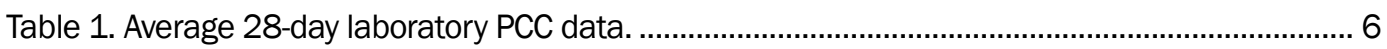

Table 2. Grooved pavement test summary and results after 15 min of simulated rain. ..................51

Table 3. Smooth pavement test summary and results after $15 \mathrm{~min}$ of simulated rain................... 51 


\section{Preface}

This study was conducted for the U.S. Air Force's Rapid Airfield Damage Recovery (RADR) program sponsored by Headquarters, U.S. Air Force Civil Engineer Center (AFCEC) at Tyndall Air Force Base, FL. Dr. Robert Diltz, AFCEC, was the technical monitor of the project.

The work was performed by the Airfields and Pavements Branch (GMA) of the Engineering Systems and Materials Division (GM), U.S. Army Engineer Research and Development Center, Geotechnical and Structures Laboratory (ERDC-GSL). Mr. Jeb S. Tingle (GM) was the ERDC RADR program manager. At the time of publication, Dr. Timothy W. Rushing was Chief, CEERD-GMA; Dr. G. William McMahon was Chief, CEERD-GM; and Mr. R. Nicholas Boone, CEERD-GVT, was the Technical Director for Force Projection and Maneuver Support. The Deputy Director of ERDCGSL was Dr. William P. Grogan, and the Director was Mr. Bartley P. Durst.

COL Bryan S. Green was the Commander of ERDC, and Dr. David W. Pittman was the Director. 


\section{Unit Conversion Factors}

\begin{tabular}{|l|c|l|}
\hline Multiply & By & To Obtain \\
\hline cubic feet & 0.02831685 & cubic meters \\
\hline cubic inches & $1.6387064 \mathrm{E}-05$ & cubic meters \\
\hline degrees Fahrenheit & $($ F-32)/1.8 & degrees Celsius \\
\hline feet & 0.3048 & meters \\
\hline gallons (US liquid) & $3.785412 \mathrm{E}-03$ & cubic meters \\
\hline gallons per minute & $6.309019 \mathrm{E}-05$ & cubic meters per second \\
\hline inches & 0.0254 & meters \\
\hline pounds (force) per square inch & 6.894757 & kilopascals \\
\hline
\end{tabular}




\section{Introduction}

\subsection{Background}

The Rapid Airfield Damage Recovery (RADR) program has developed technologies to return damaged runways and taxiways to full operational sortie production within $3 \mathrm{hr}$ (objective) to $6.5 \mathrm{hr}$ (threshold) after an attack. The threshold of $6.5 \mathrm{hr}$ is the maximum time allotted for crater repair on a minimum operating strip (MOS), yet the objective to repair the craters in $3 \mathrm{hr}$ is the desired goal.

The technologies involved in the crater repair process include the use of compact track loaders (CTLs) featuring wheel saw, broom, and bucket attachments, wheeled excavators, front-end loaders, utility vehicles, telehandler forklifts, a simplified volumetric mixer, dump trucks, water trucks, a flatbed trailer, rapid-setting cementitious materials, and a variety of concrete finishing tools. These technologies and processes have been tested in dry weather, and initial testing has been completed in wet weather. The RADR process must be capable of being employed on both grooved and smooth pavements when crater repairs have to be conducted during periods of inclement weather.

The crater repair equipment has shown to work well in wet weather; however, runoff water presents a challenge for excavated crater repairs, particularly for grooved pavements (Bell et al. 2013; Pullen et al. 2014). Figure 1 shows a crater repair after the excavation process, and Figure 2 shows a crater repair after the capping process. Crater repairs that are in the backfilling and capping phases of the process need to be protected from wet weather. Excessive water can cause performance problems with the backfill and/or surface cap material. Thus, inclement weather scenarios require additional materials, equipment, and techniques to successfully complete repairs. Various materials, equipment, and processes have been identified with minimal testing since the initial inclement weather crater repair evaluations. 
Figure 1. Excvated crater repair area before backfill and capping.

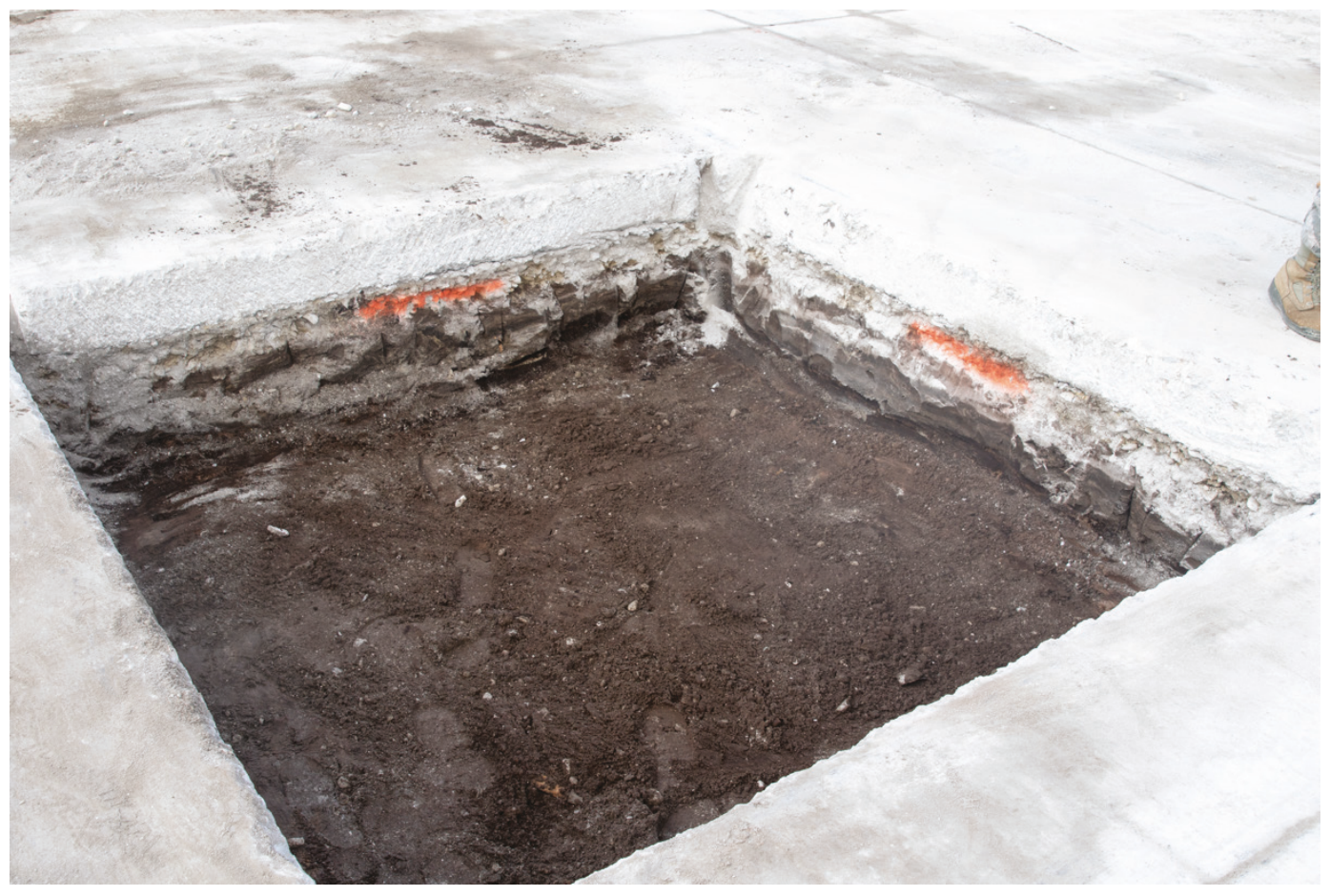

Figure 2. Crater repair capped with rapid-setting concrete.

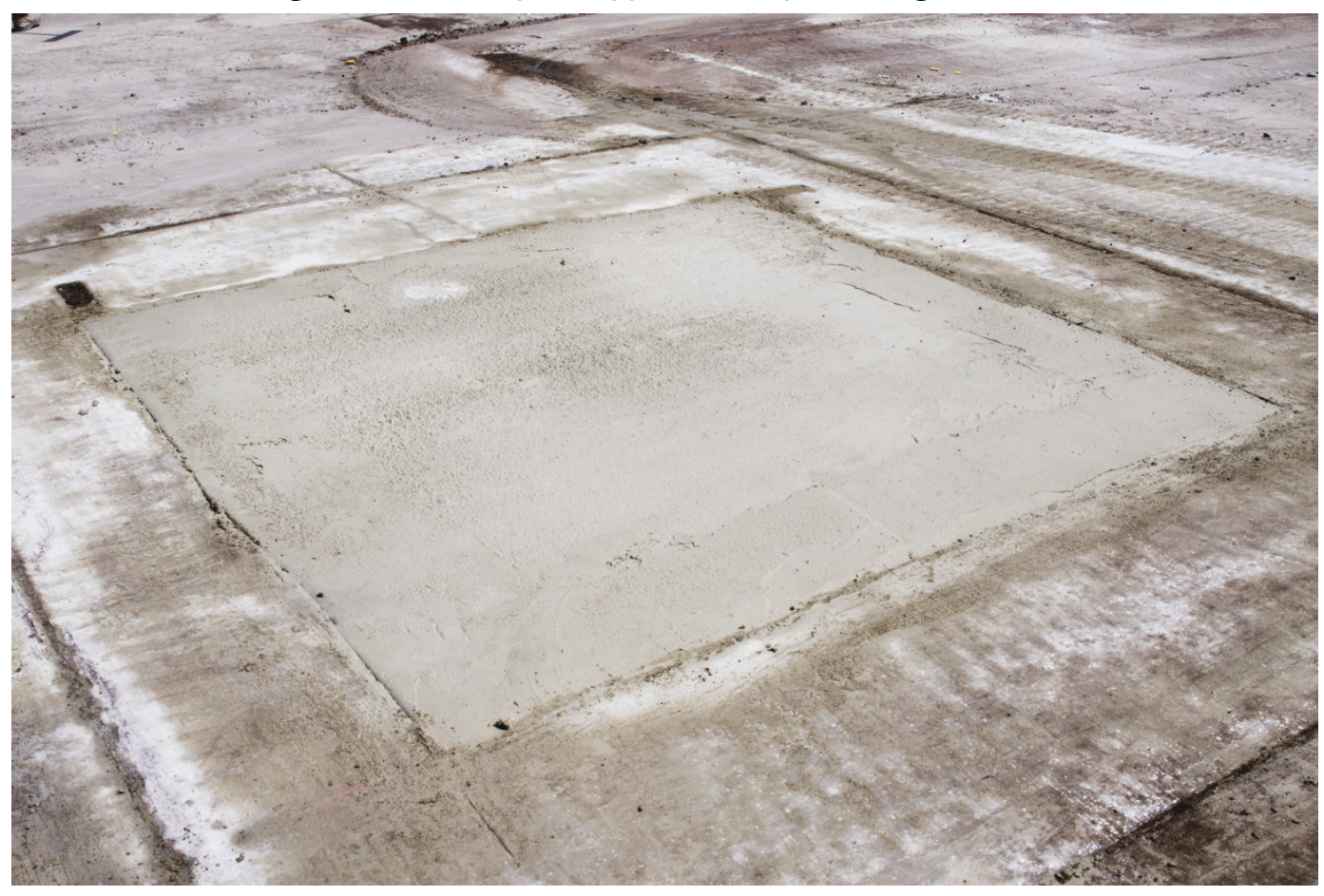


A kit (Inclement Weather Crater Repair Tool Kit) containing the necessary supplemental small tools and equipment for the RADR process during cold and/or wet weather was developed (Bell and Tingle 2017). However, some of the tools and equipment in the kit have not been thoroughly tested on grooved pavements. Several water mitigation barriers in the packaged kit are redundant items. Also, grooved pavements present an additional challenge for the prevention of rainfall runoff flowing into the open crater during the repair process.

\subsection{Objective}

The objective of this research was to identify the best water mitigation technologies to use for repairing craters on grooved and smooth pavements during periods of rainfall. The key technologies were barriers for protecting the open crater repair area from water runoff. Specific objectives for this project included:

1. Reviewing the contents of the RADR Inclement Weather Crater Repair Tool Kit,

2. Identifying materials, equipment, or tools already in the kit capable of aiding in the runoff control during crater repair on grooved and smooth pavements during rainfall,

3. Conducting market research to identify alternative materials, equipment, or tools capable of aiding in runoff control during crater repair on grooved and smooth pavements during rainfall, and

4. Evaluating the potential materials, equipment, or tools capable of aiding in runoff control during crater repair on full-scale grooved and smooth pavement structures during rainfall.

\subsection{Scope}

The evaluation took place on a full-scale portland cement concrete (PCC) test section at the Engineer Research and Development Center's (ERDC) Outdoor Pavement Test Facility. One of the 15-in.-thick, 20-ft-by-20-ft slabs on the test section was grooved according to Unified Facilities Guide Specifications 3201 26.71, Grooving for Airfield Pavements (2008). Approximately 5-in.-wide, 9.5-ft-long, and 6-in.-deep catch basins were cut in the grooved slab and smooth slab to collect and measure the water pooled from the simulated rainfall. A calibrated portable rain system was constructed overhead to simulate rainfall. Each barrier was set up and evaluated with a set amount of rainfall of approximately $1 \mathrm{in} . / \mathrm{hr}$. The barriers were visually and quantitatively evaluated. 


\section{Test Section Description}

\subsection{PCC test section construction}

A full-scale test section was constructed in March 2016 and consisted of 15- and 18-in.-thick PCC pavement to provide a testing area for conducting PCC-related projects. The test section was located on a pavement test area at ERDC named Outdoor Pavement Test Facility. The plan and profile views of the test section are shown in Figure 3. The slabs were numbered to identify the slab locations used for testing.

Figure 3. Plan and profile views of test section.

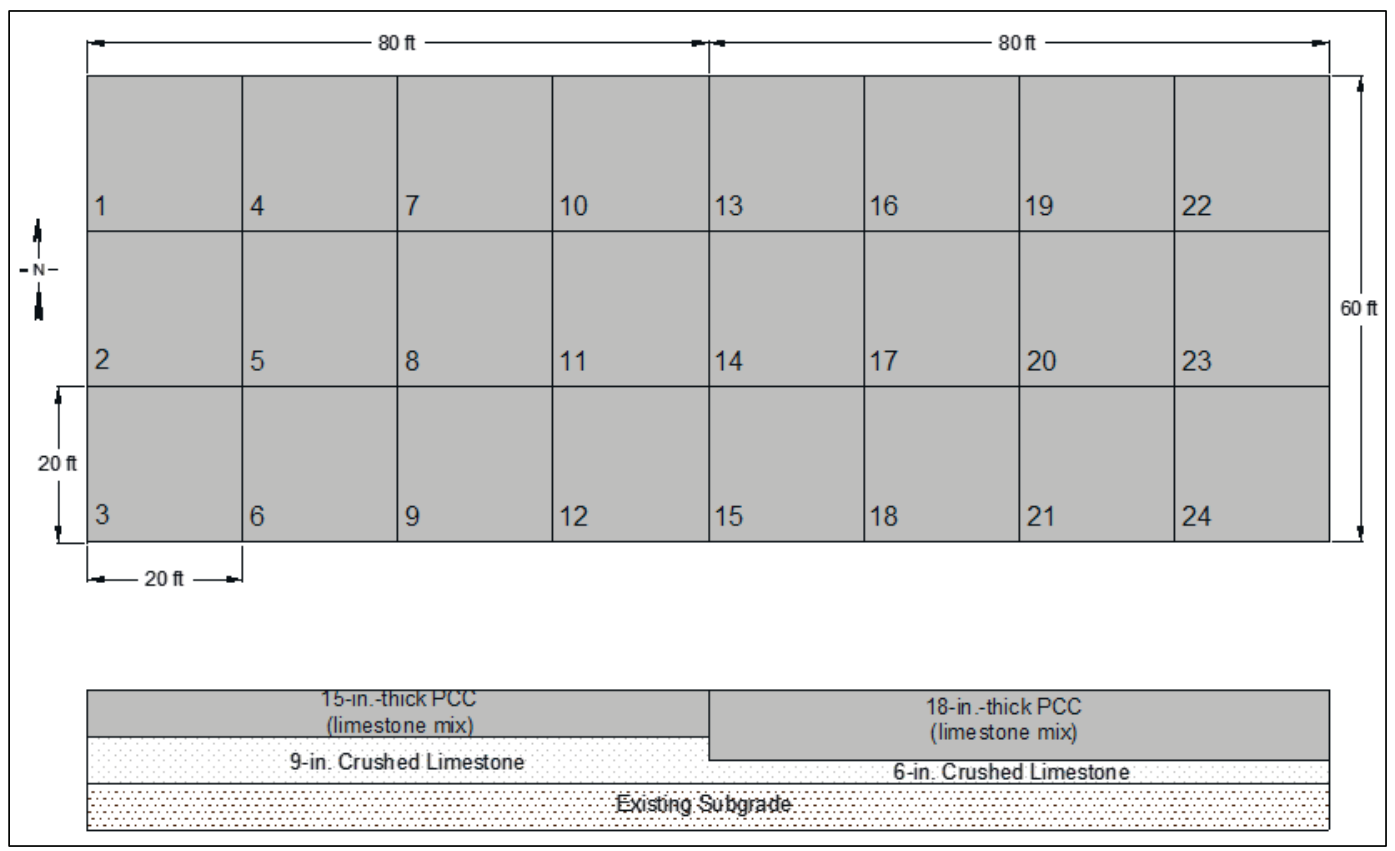

The PCC pavement was constructed of concrete designed to meet minimum flexural strength requirements for airfield PCC of 650 psi and a 5,00o-psi unconfined compressive strength (UCS). Twelve slabs were 15 in. thick, and 12 slabs were 18 in. thick; each slab was 20 by $20 \mathrm{ft}$. The slab dimensions were in accordance with maximum Department of Defense (DoD) joint spacing specifications prescribed in UFC 3-260-02 for PCC airfield pavements greater than 12 in. thick (Headquarters Army, Navy, Air Force 2001).

The PCC mixture was produced using a local PCC mix design, utilizing crushed limestone as the coarse aggregate, capable of achieving a minimum 5,000 psi UCS after 28 days of cure. The concrete surface was constructed in a fixed-form placement and placed on grade. The existing 
subgrade was graded prior to construction with a $0.4 \%$ cross-slope to allow for drainage. During placement, the concrete was consolidated with spud vibrators and struck off using a vibratory truss screed. Figure 4 shows the placement of the center lane of the PCC pavement test section.

Figure 4. PCC test section construction.

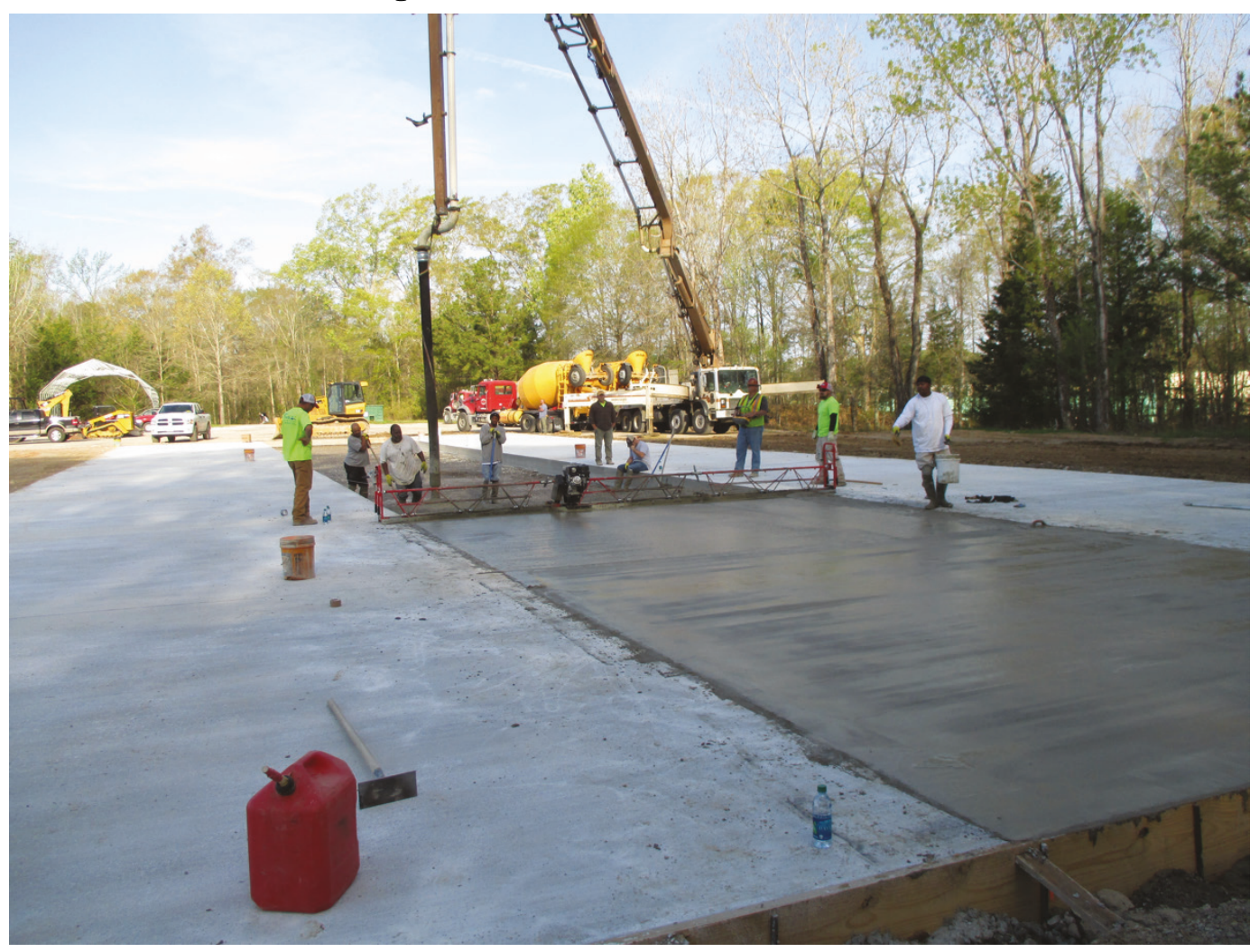

The PCC section was completed with a light broom finish, coated with an acrylic curing and sealing compound meeting ASTM C309 (2011) specifications, and then saw cut to provide transverse and longitudinal joints. The 15- and 18-in.-thick sections were saw cut to a depth of 3 in. after the PCC was finished.

During placement, test specimens were prepared in accordance with ASTM C39/C39M (2016a) for compressive cylinders and ASTM $\mathrm{C} 78 / \mathrm{C} 78 \mathrm{M}$ (2016b) for flexural beams. Two sets of three beam specimens and three cylinder specimens were prepared from the raw mix delivered for each paved lane for a total of 18 cylinders and 18 beams.

Laboratory test results for the cast specimens are shown in Table 1. The strengths of the PCC exceed the 5,000-psi UCS and 650-psi flexural strength requirements generally specified for PCC airfield pavements. 
Table 1. Average 28-day laboratory PCC data.

\begin{tabular}{|c|c|c|}
\hline PCC Area & UCS (psi) & Flex Strength (psi) \\
\hline Lane 1 & 8,560 & 880 \\
\hline Lane 2 & 8,900 & 940 \\
\hline Lane 3 & 8,530 & 880 \\
\hline
\end{tabular}

\subsection{PCC pavement grooving}

One 20-ft-by-20-ft slab of the test section was needed to execute the project. Slab 4 (Figure 3) was selected to serve as the test area for the wet weather testing on grooved pavements. Slab 4 is located on the low end of the test section, where rainwater would drain to the slab.

Slab 4 was grooved according to UFGS 3201 26.71, Grooving for Airfield Pavements (2008). The guidelines state that pavements should not be grooved until they are at least 30 days old. Grooving should not be completed within 6 in. of transverse joints or working cracks. Furthermore, the guidelines state that grooving should be $1 / 4$ in. $(+1 / 16$ in. or -0 in.) wide and $1 / 4$ in. $( \pm 1 / 16$ in.) deep. The spacing between the groove centers should be 1.5 in. $(-1 / 8$ in.).

Due to the small test area needed for this project, the PCC slab was grooved by using a walk-behind saw equipped with one diamond sawcutting blade rather than a grooving machine. Chalk lines spaced 1.25 in. apart and sprayed with clear laquer served as a guide for the saw operator. Grooving took place in May 2016 - one and a half months after PCC placement. Figures 5 through 10 show the pavement grooving process for Slab 4. Slab 2 was used for the smooth pavement testing. 
Figure 5. PCC slab before grooving.

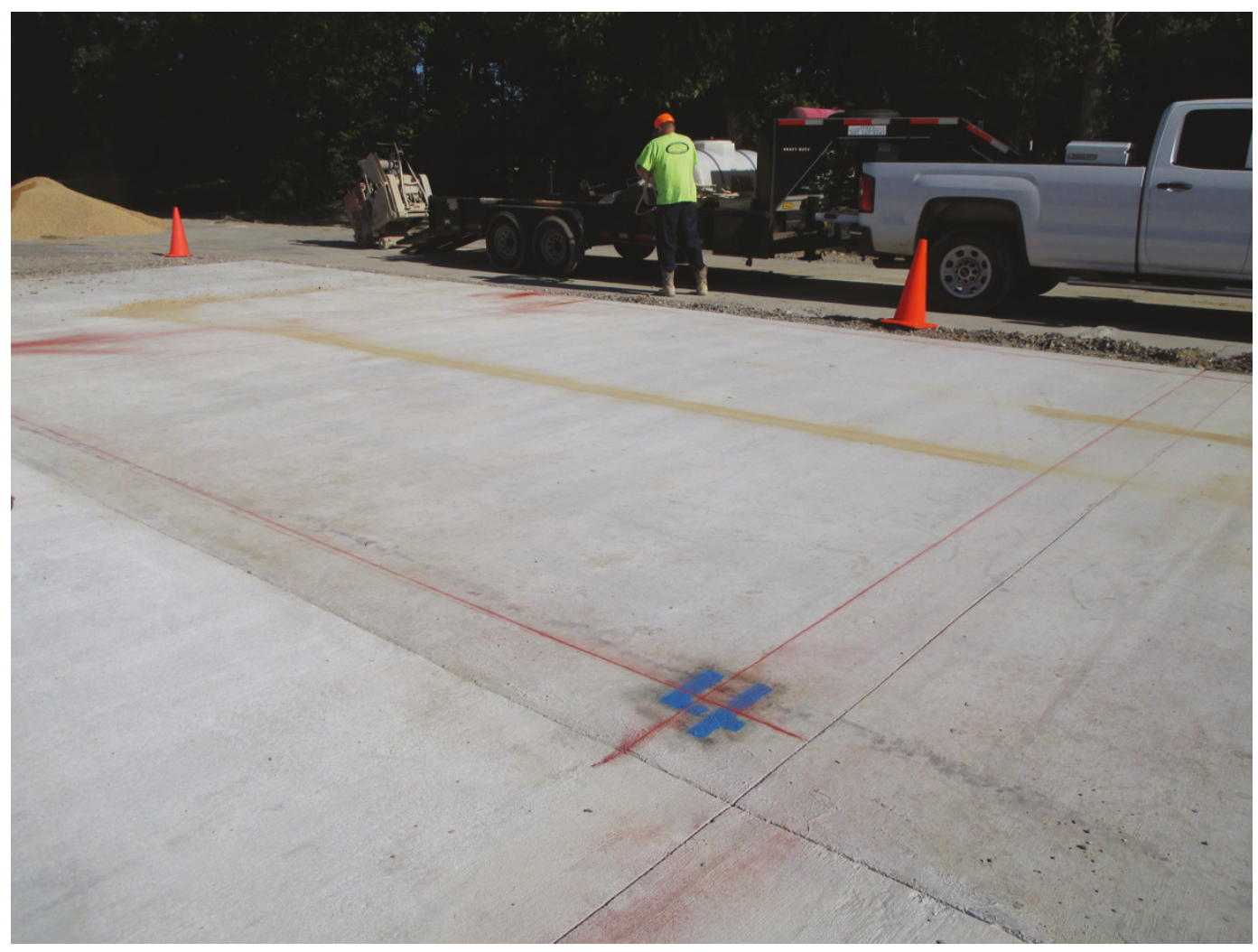

Figure 6. Measuring the slab for chalked lines before grooving.

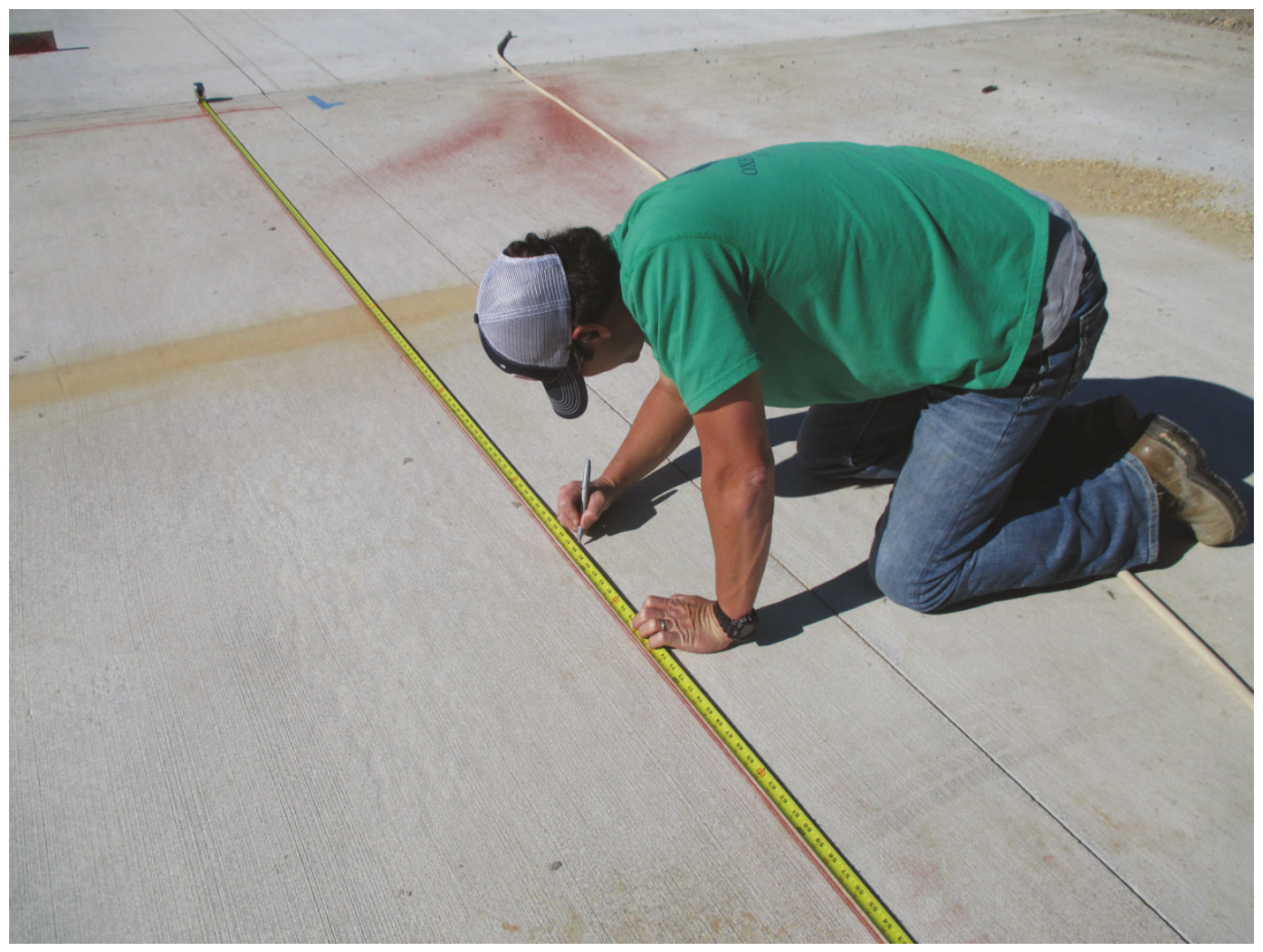


Figure 7. Popping chalked lines for grooving.

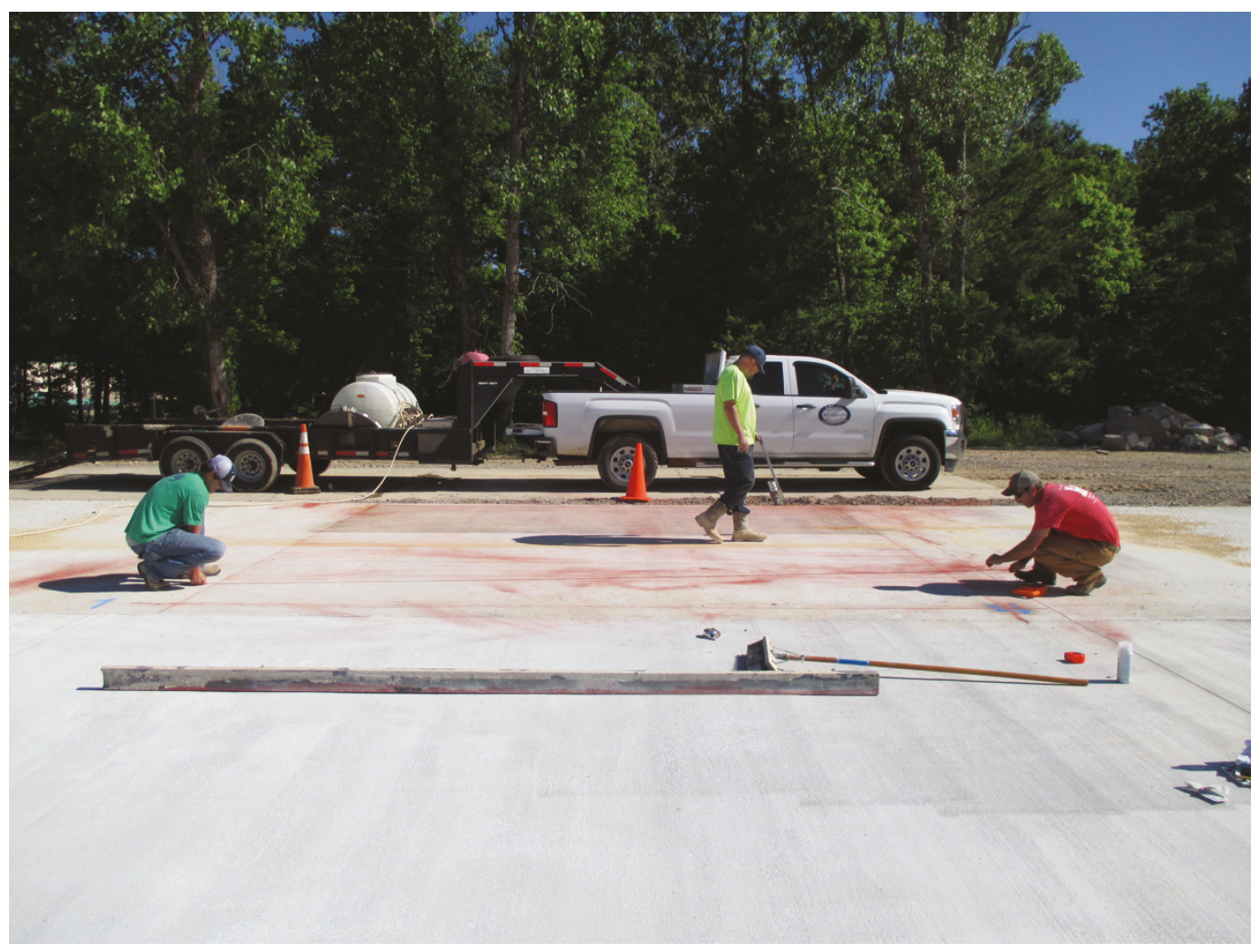

Figure 8. Spraying laquer over chalked lines.

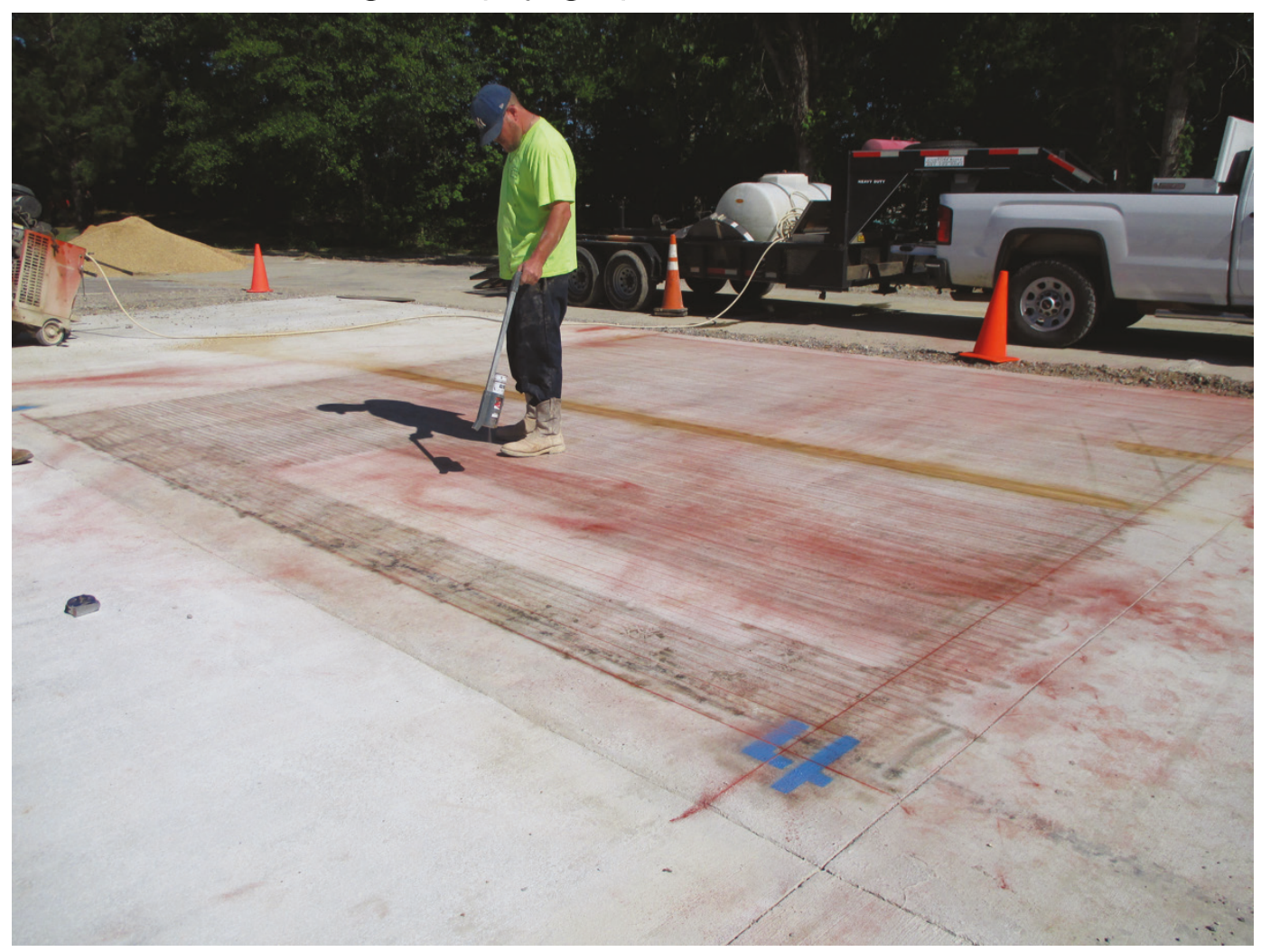


Figure 9. 20-ft-by-20-ft grooved slab.

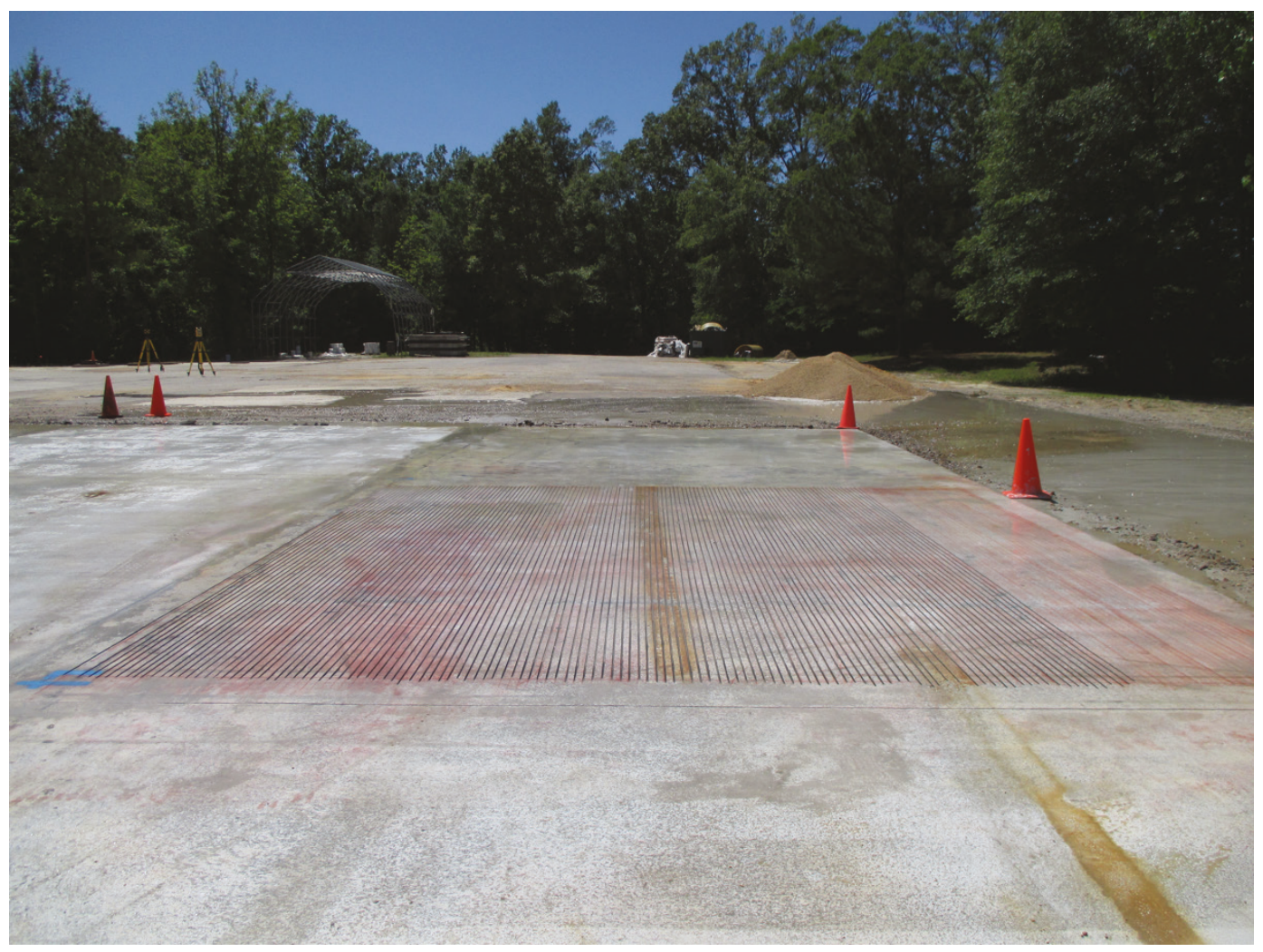

Figure 10. Grooved PCC pavement.

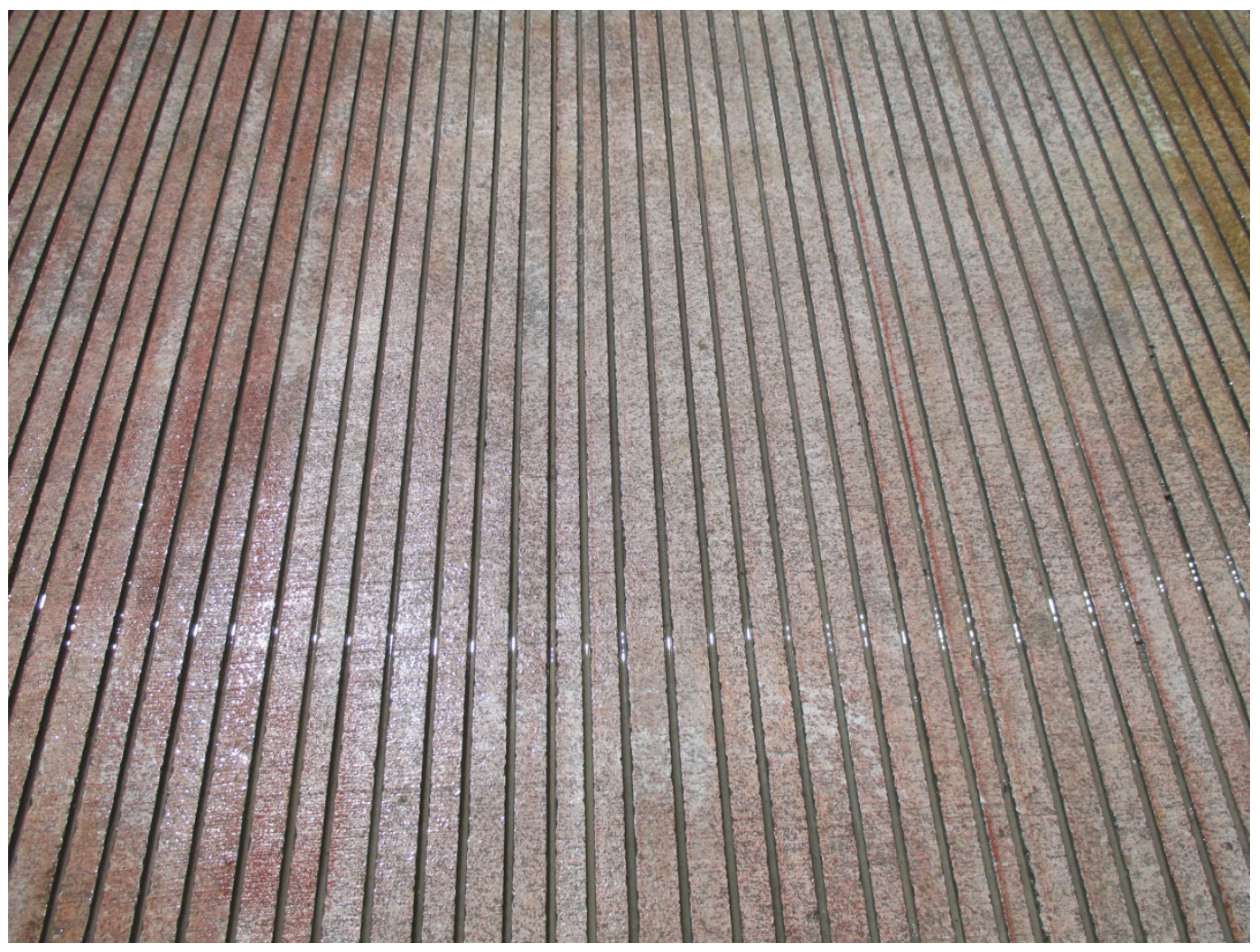




\subsection{PCC rainwater catch basin}

A catch basin was cut into the concrete of the grooved and smooth slabs so that the amount of rainwater that permeated the barriers or ran off the tent could be measured and quantified. The catch basins were cut by using a Caterpillar SW45 wheel saw mounted to a Caterpillar 279C XPS CTL (Figure 11). The catch basins were cut near the low end of the slabs so that the rainwater was able to flow into the open cuts (Figure 12).

The wheel saw is round, so the ends of the cut basin were not square. Rapidsetting concrete was added to the ends of the basins so that the volume of each basin could be easily measured, as shown in Figure 13. Grooving was added to the additional concrete on the ends of the basin cut into the grooved slab.

For the grooved slab, the basin was measured to be $9.5 \mathrm{ft}$ long, $6 \mathrm{in}$. wide, and $5 \mathrm{in}$. deep for a total volume of $2 \mathrm{ft}$. The basin cut into the smooth slab was $9.5 \mathrm{ft}$ long, $3.6 \mathrm{in}$. wide, and $8 \mathrm{in}$. deep for a total volume of $2 \mathrm{ft} 3$.

Figure 11. Cutting basin into the grooved slab using a wheel saw.

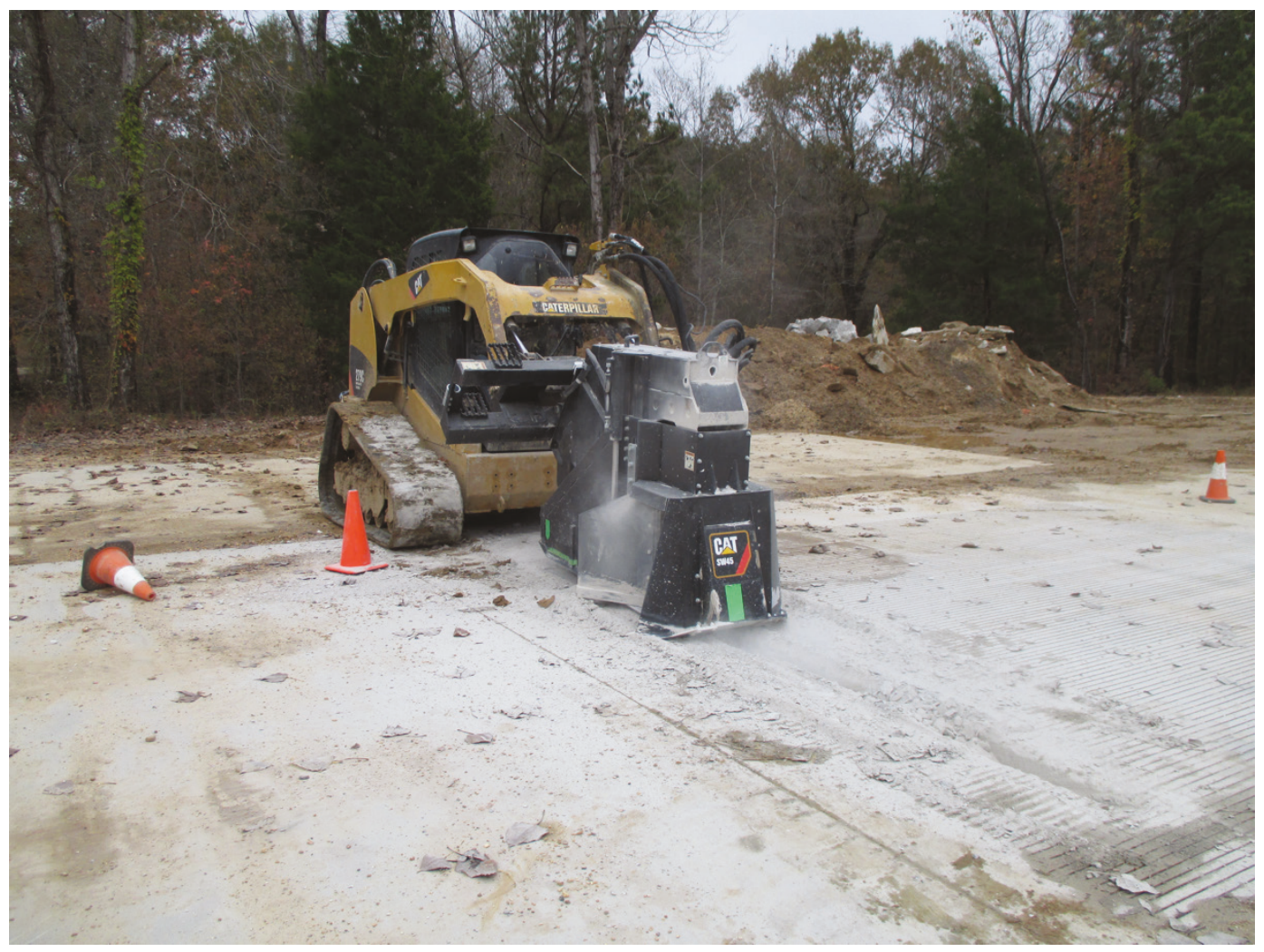


Figure 12. Catch basin cut near low end of grooved slab.

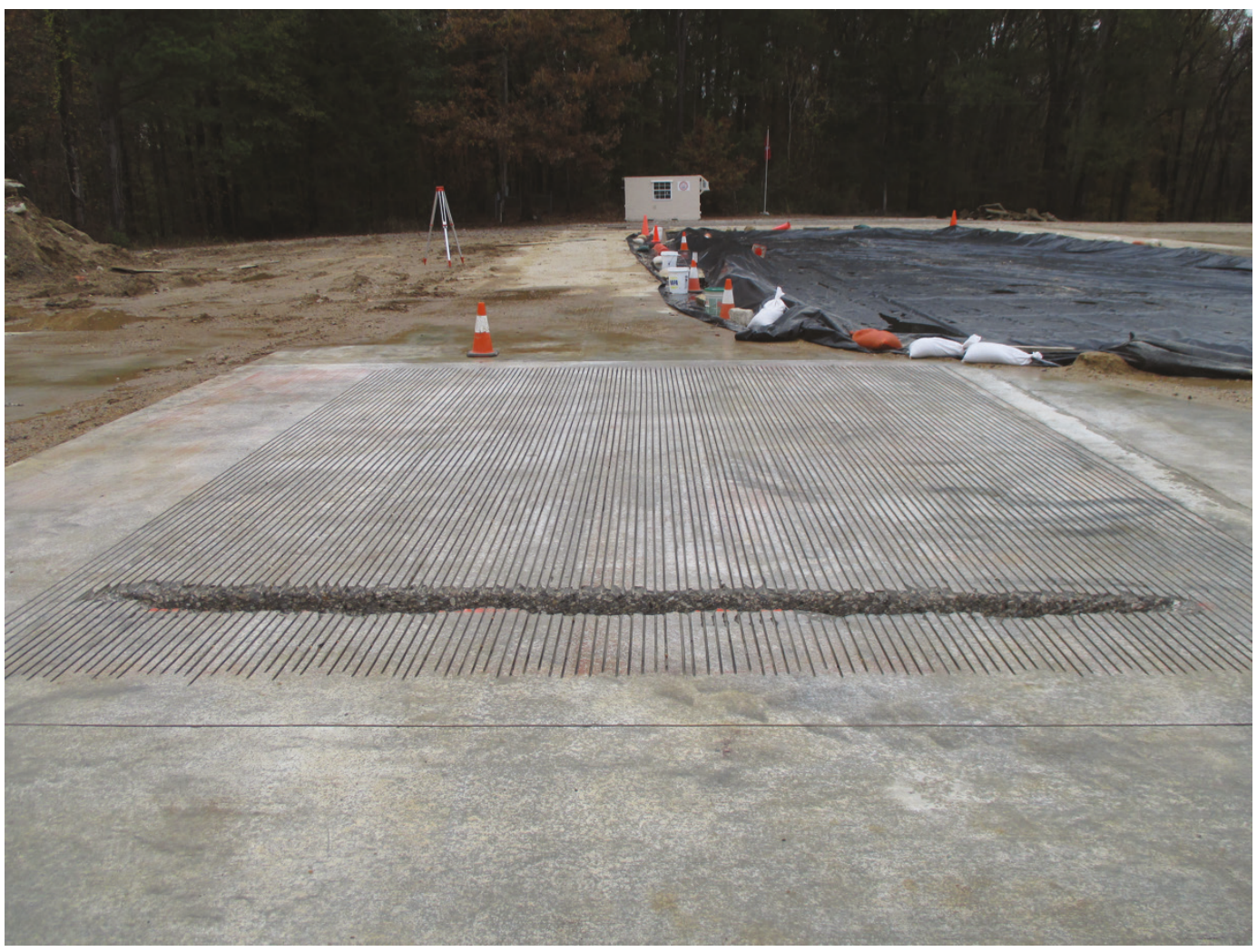

Figure 13. Concrete placed at end of the catch basin.

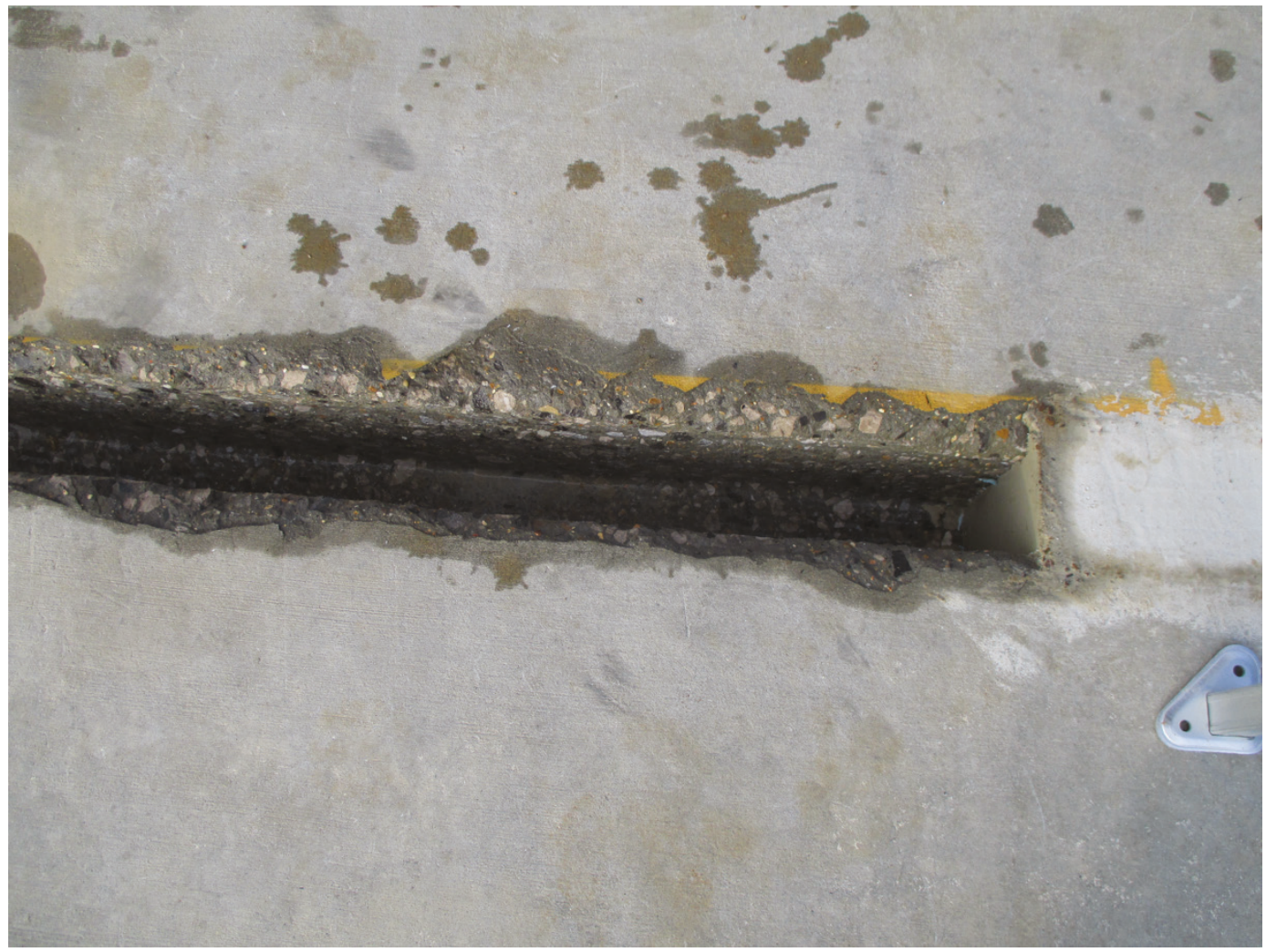




\subsection{Rain simulation system}

Simulated rainfall was produced by the construction of an overhead sprinkler system, which was mounted on 12-ft-high 2-in.-by-4-in. wood using four 4-in.-by-4-in. wooden legs for stability. The overall rain system was $12 \mathrm{ft}$ by $12 \mathrm{ft}$. Figure 14 shows the rain system being lifted into place. The 2-in.-by-4-in. wood held polyvinyl chloride (PVC) pipes affixed with five sprinkler heads spaced throughout the top of the system - one on each corner and one in the middle (Figure 15). One rain gauge was mounted on the rain system, and four rain gauges were placed under the rain system inside the tops of traffic cones. Figure 16 shows the rain gauge being mounted on the rain system. The sprinkler system, shown in operation in Figure 17, simulated a constant rainfall of approximately $1 \mathrm{in} . / \mathrm{hr}$ during each test.

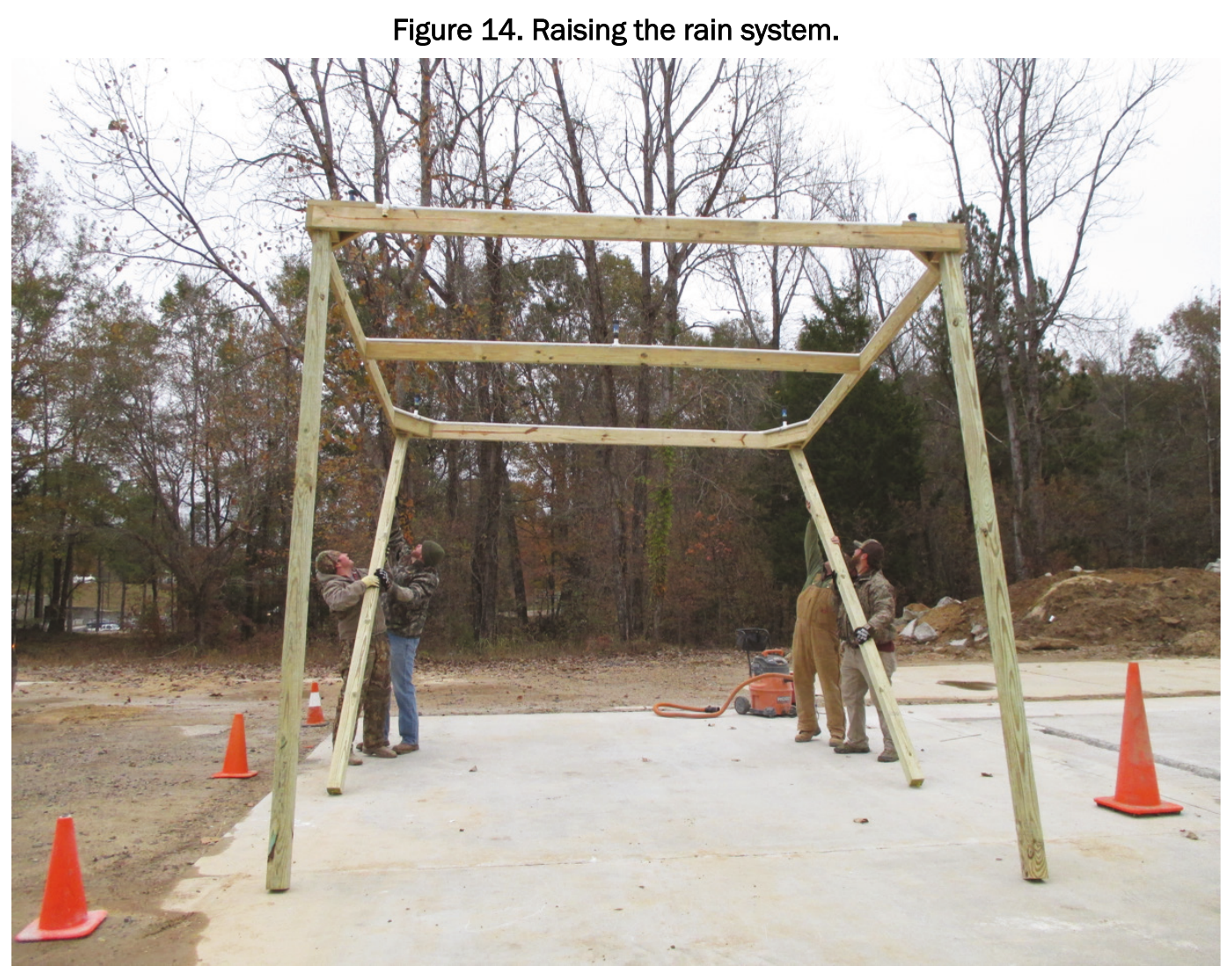


Figure 15. Sprinkler head and hose connection on the rain system.

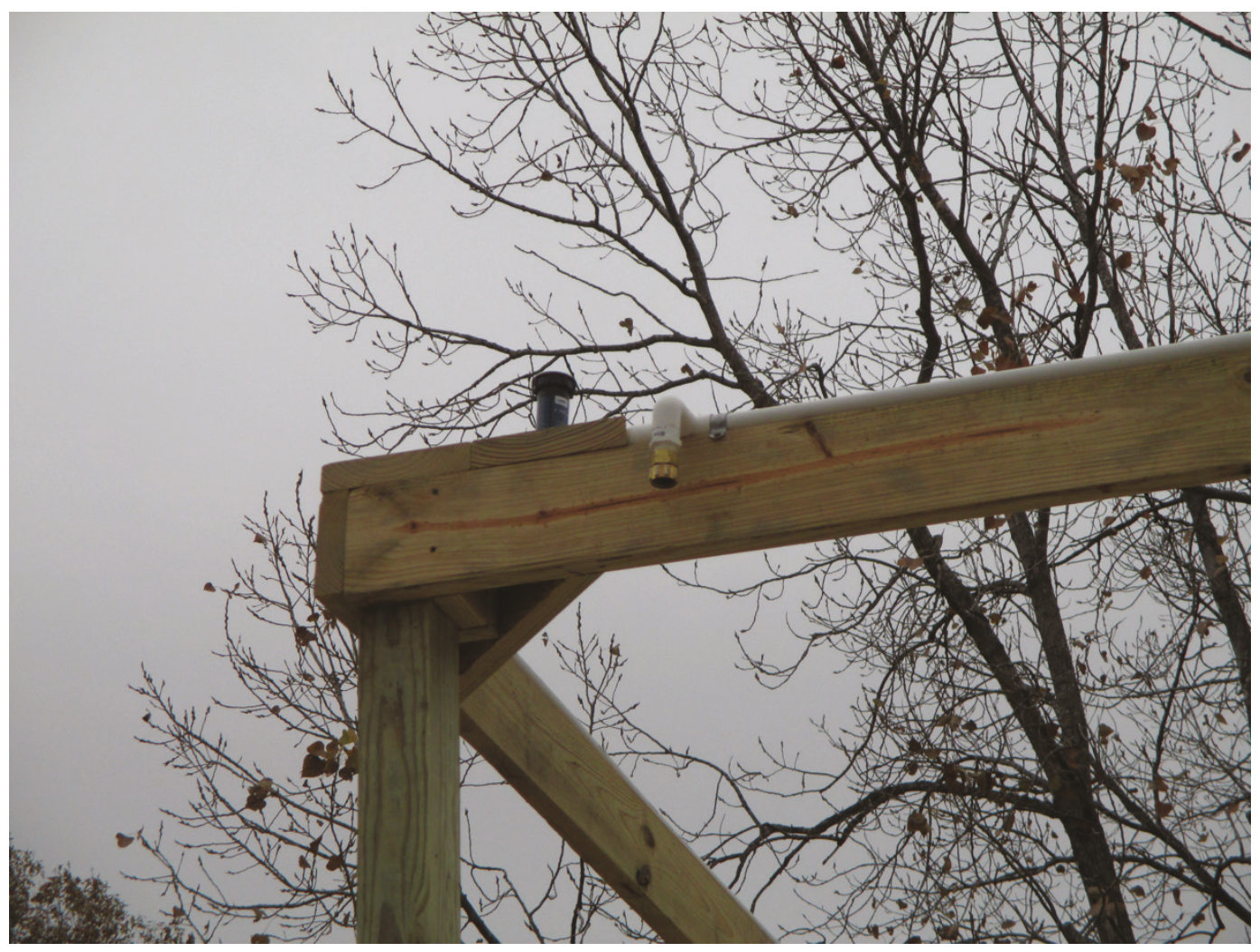

Figure 16. Mounting a rain gauge on the rain system.

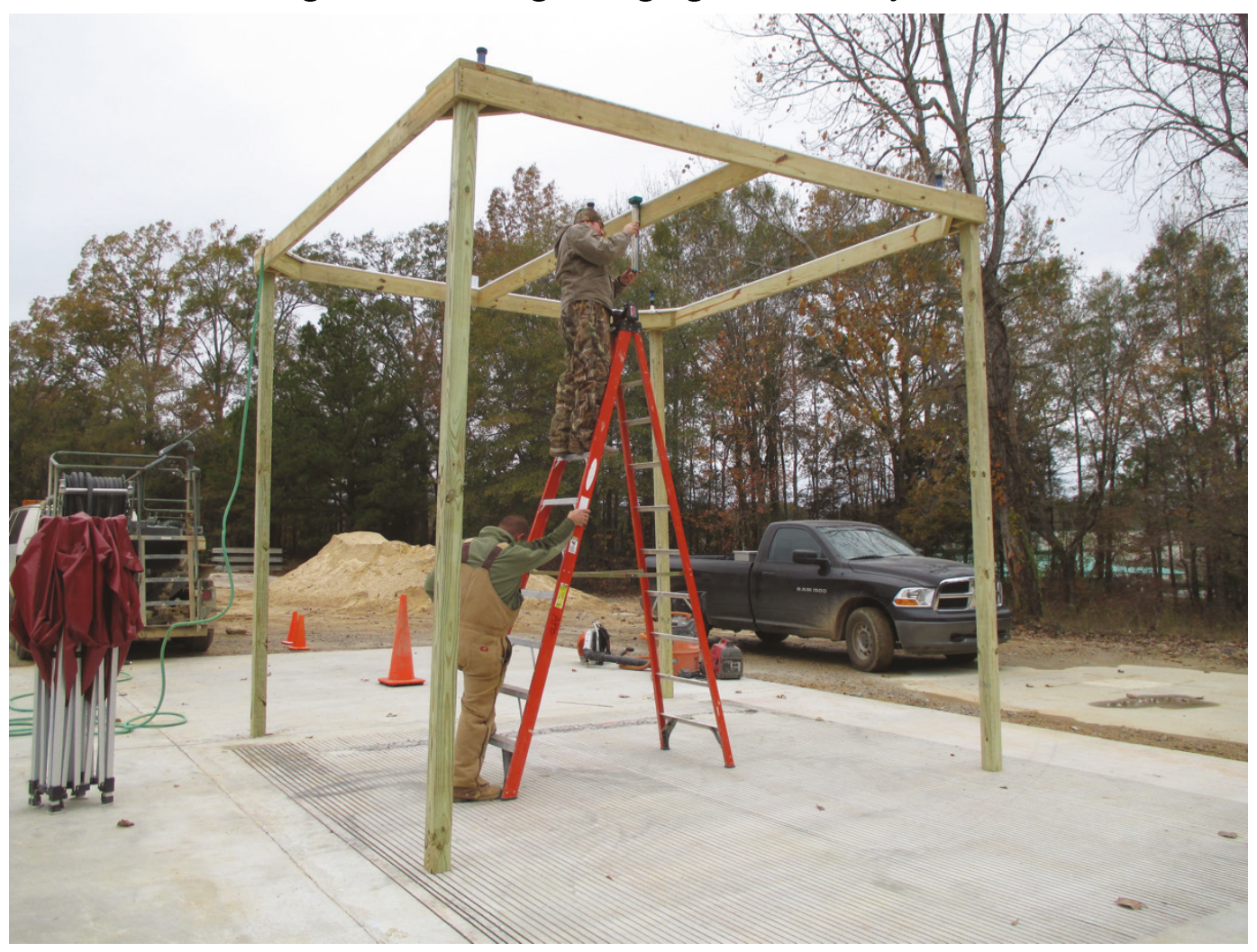


Figure 17. Simulated rainfall of $1 \mathrm{in} . / \mathrm{hr}$.

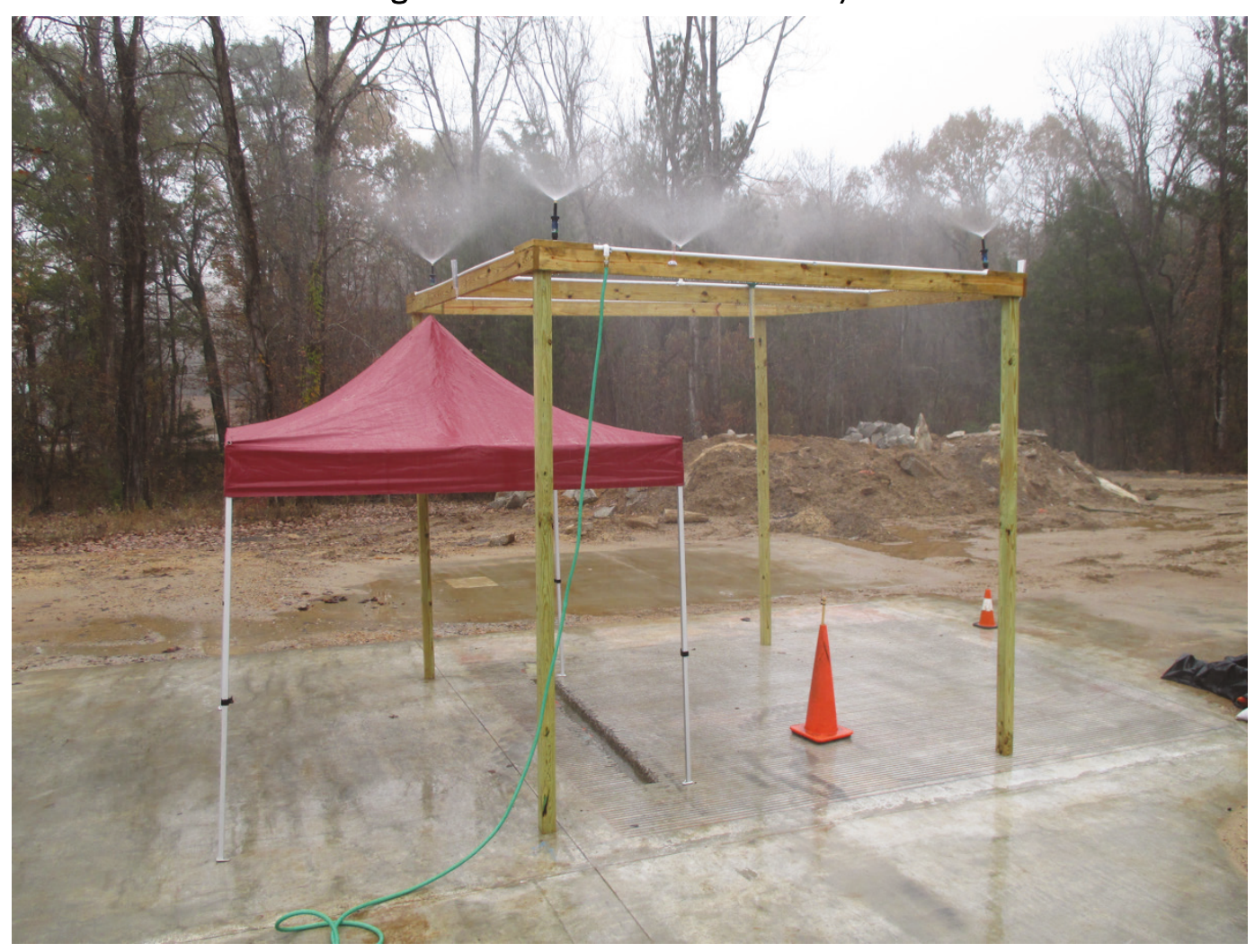




\section{Evaluated Technologies}

Eight tests using the water mitigation technologies described in this chapter were performed on the grooved and smooth pavements, including the controls. The controls included simulating rainfall near the opening of the crater repair without using any protective barrier except for the pop-up tent overhead. The pop-up tent was used for all eight tests. The 10-ft-by10 - $\mathrm{ft}$ tent is a necessity for repairing small craters in wet weather. Many of the water mitigation technologies have been tested previously on smooth pavements, but none have been tested on grooved pavements.

The dry-line marker, fire hose, pop-up tent, tarp, and containment dikes are currently included in the Inclement Weather Crater Repair Tool Kit (Bell and Tingle 2017). However, the dry-line marker, fire hose, and containment dikes are redundant items because each serves the purpose of surrounding the perimeter of an open repair to mitigate surface runoff water into the open repair. Only one type of these technologies is needed to perform as a water barrier around open repairs; however, they were all evaluated again to determine their effectiveness on grooved pavements and to identify the best option(s) for both smooth and grooved pavements.

\subsection{Pop-up tent}

Pop-up tents are intended to be used over the excavated repairs to prevent direct rainfall from adding excessive water to flowable fill or rapid-setting concrete materials during the backfill and capping processes, particularly when using the volumetric mixer. Pop-up tents also serve as a protective cover while the backfill and capping surfaces are curing. Pop-up tents have been successfully tested in previous wet weather crater repair evaluations on smooth pavements (Bell et al. 2013; Pullen et al. 2014).

The pop-up tent used for this evaluation is shown in Figure 18. The tent was $10 \mathrm{ft}$ by $10 \mathrm{ft}$ with a 7 -ft-high clearance. It was made of a heavy-duty, industrial-grade 6061-T6 anodized aluminum frame with a vinyl cover. The heavy-duty tent was previously successfully tested for sturdiness using a backpack blower that produced air speeds of approximately $180 \mathrm{mph}$ (494 ft3/min). The blower was used under and around the tent, and the tent never moved. The tent can be anchored using sand bags for extra support, if desired. 
Figure 18. Pop-up tent.

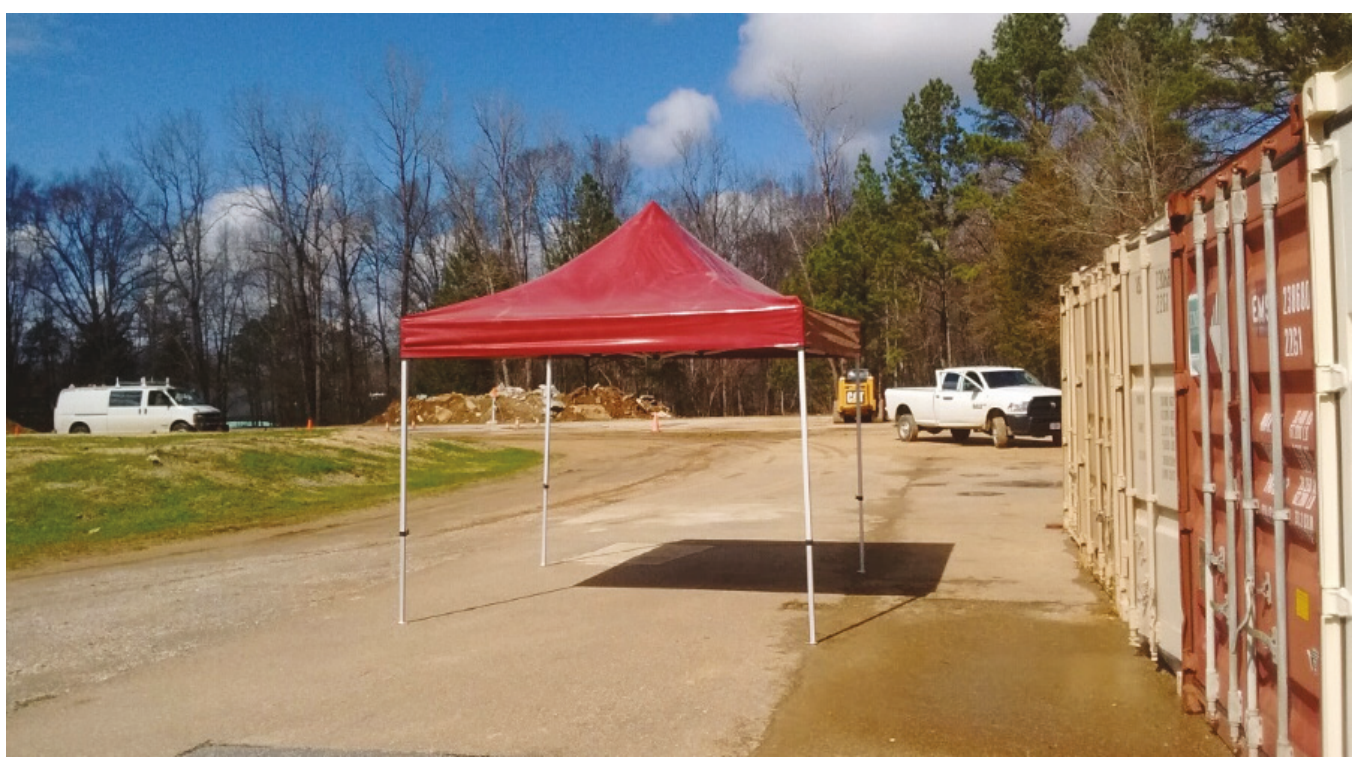

\subsection{Dry-line marker}

A dry-line marker's intended purpose is to paint lines on turf using chalk or paint. However, for water mitigation, the line marker is filled with sand. Sand is sieved before placing in the dry-line marker; sieves are included in the Inclement Weather Crater Repair Tool Kit. The sand is deposited along the perimeter of the open repair. The line marker is pushed back and forth until the desired amount of sand has been deposited, essentially forming a sand berm around the repair. The opening for the sand to exit the line marker is approximately $1 \mathrm{in}$. wide and $4 \mathrm{in}$. long. Figure 19 shows the dryline marker used for this evaluation.

\subsection{Fire hose}

Capped and plugged fire hoses partially filled with water were evaluated as water barriers on the grooved and the smooth pavements. The fire hose segments were $30 \mathrm{ft}$ long and $2.5 \mathrm{in}$. in diameter. The fire hose was tested for asphalt crater repairs on smooth pavements in a previous evaluation; however, it was used in conjunction with a tarp, sand, and containment dikes (Pullen et al. 2014). Figure 20 shows a capped and plugged fire hose segment before it is partially filled with water. 
Figure 19. Dry-line marker.

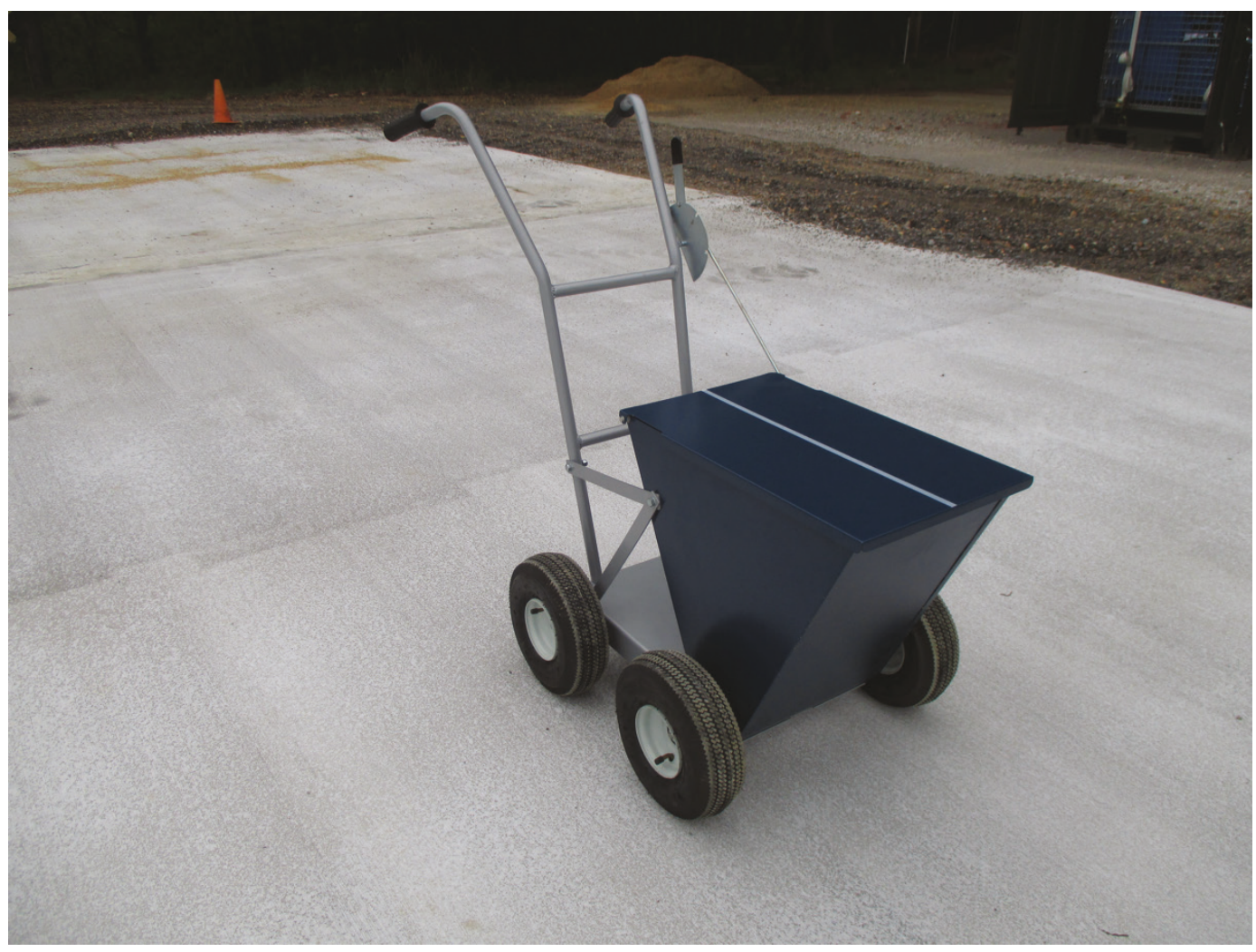

Figure 20. Fire hose.

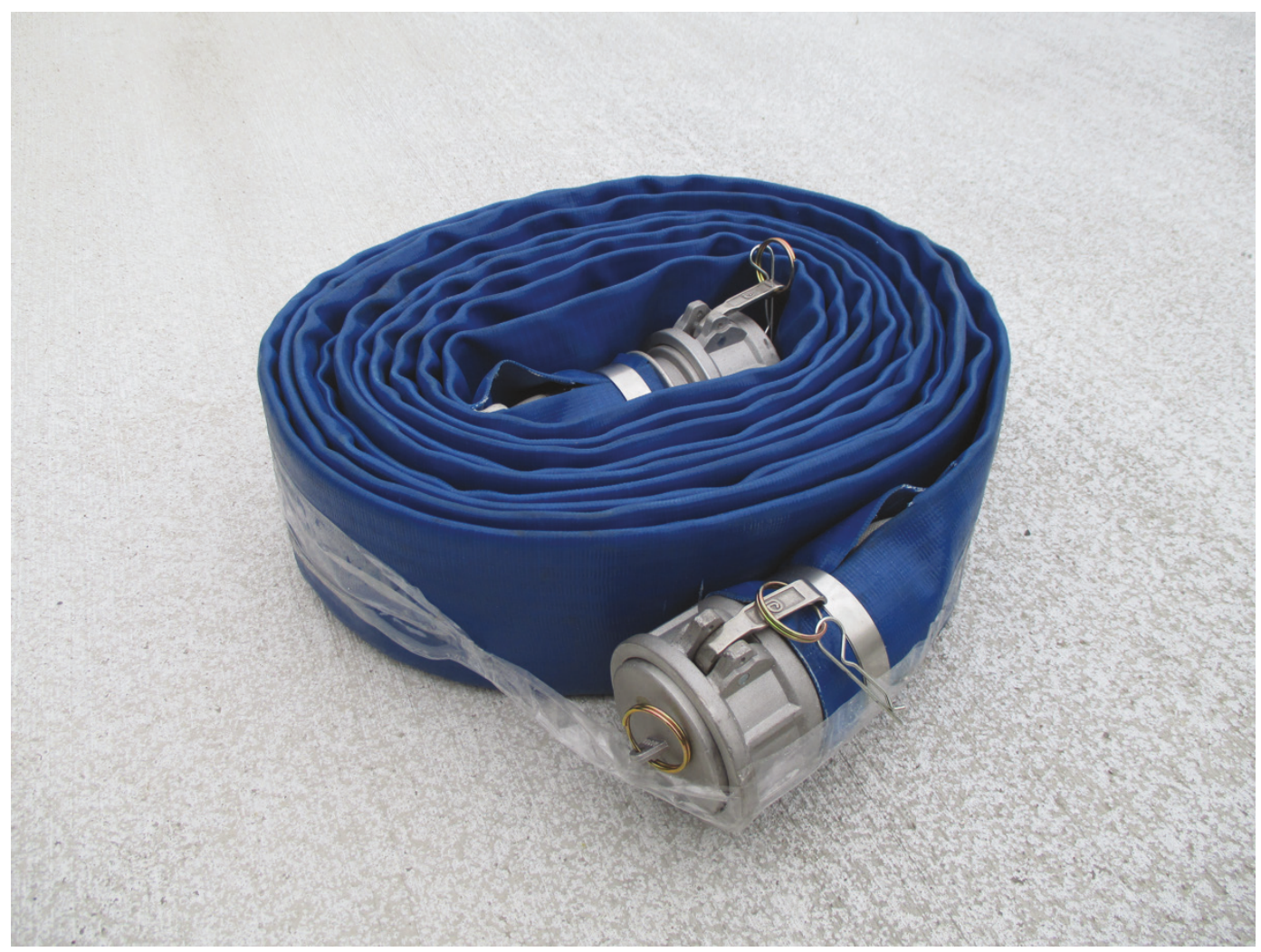




\subsection{Tarp}

The 20-ft-by-16-ft coated polyvinyl tarp's intended crater repair purpose was to cover the excavated crater to protect the backfill surface from rainfall after placement while waiting for the surface capping to begin. It has also been evaluated in the past as a cover to protect the asphalt surface caps while compaction is taking place (Pullen et al. 2014). The coated vinyl tarps will not melt when placed over the hot asphalt surface during compaction and curing. Figure 21 shows the tarp folded for storage.

Figure 21. Coated polyvinyl tarp, folded for storage.

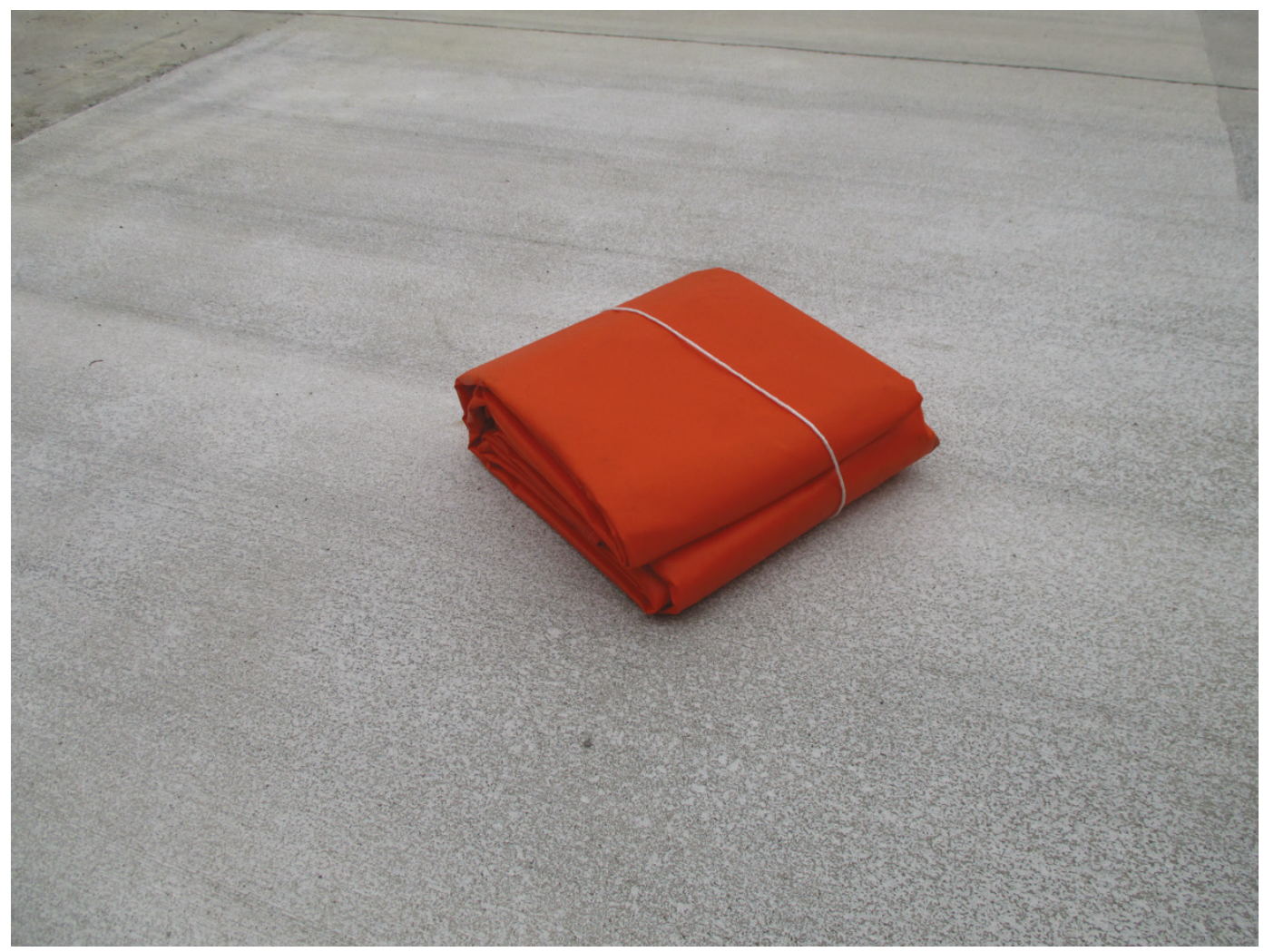

\subsection{Containment dike}

Low profile, polyurethane ultra-spill berms, or containment dikes, have been tested on smooth pavements as a possible solution for mitigating rainwater into crater repairs. The containment dikes come in 10-ft-long, 2.25-in.-wide, and 1.375-in.-high sections that can be connected. Figure 22 shows the containment dike with a close-up of the connector end. The berms can be stored and reused. 
Figure 22. Containment dike.

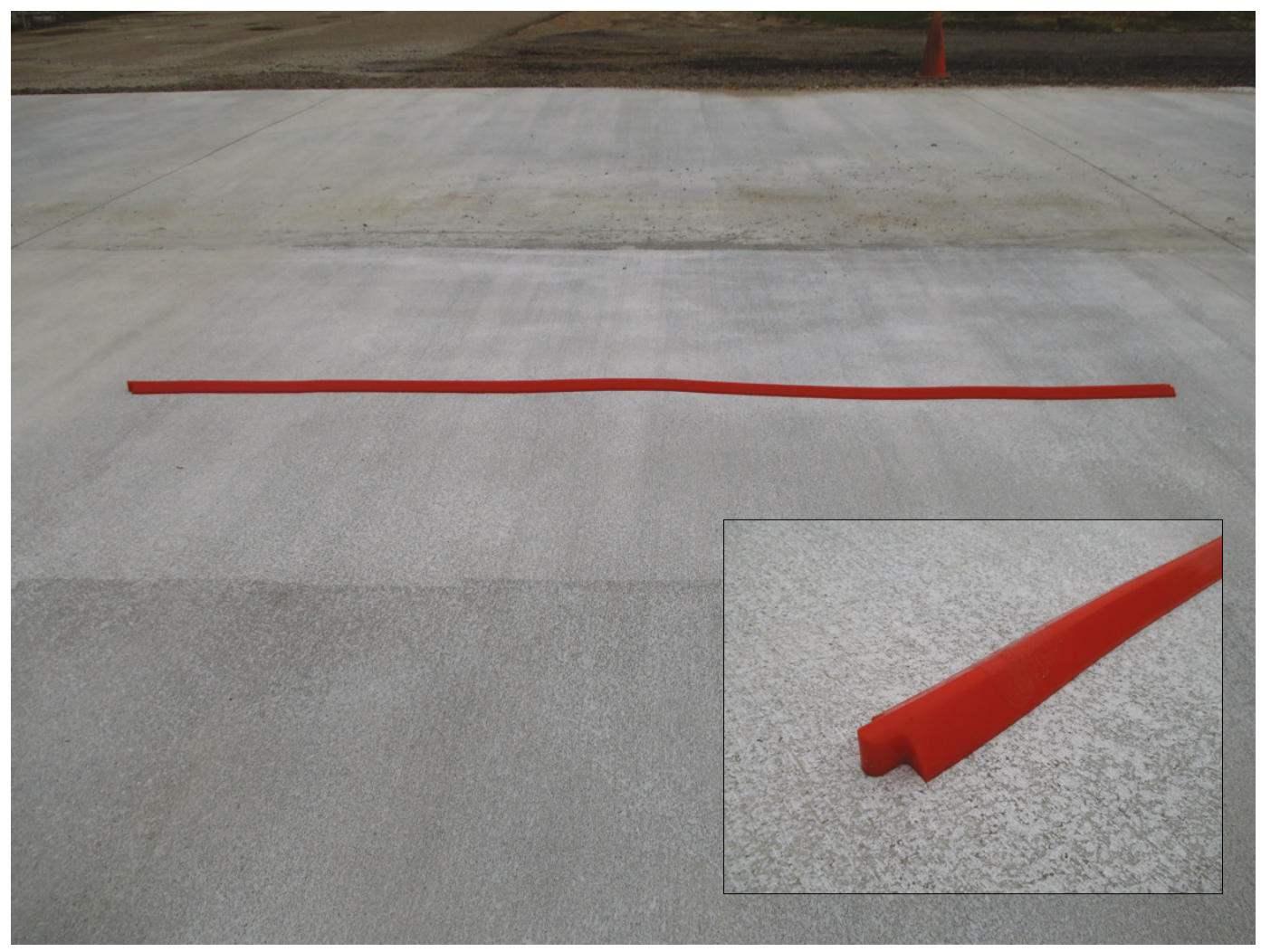

\subsection{Sand}

Sand was evaluated for its potential to form a berm to protect an open repair from water mitigation. Sand was also used and evaluated in conjunction with a tarp and a fire hose.

For this project, sand was deposited by using a hand scoop, which is included in the Inclement Weather Crater Repair Tool Kit, or placed by using the dry-line marker and evaluated. The timing of placing a sand berm by pouring out of a 5 -gal bucket was also recorded. For this evaluation, the sand moisture was 3.5 and $4 \%$ before testing on the grooved and smooth pavements, respectively.

\subsection{Quick Dam Expanding Barrier}

Quick Dam Expanding Barriers are not included in the Inclement Weather Crater Repair Tool Kit; however, they were included in this test to determine how well they perform on grooved and smooth pavements. The barriers are $10 \mathrm{ft}$ long and $6 \mathrm{in}$. wide, and they activate and swell when exposed to water. A Quick Dam Expanding Barrier can be used straight out 
of the package or presoaked so that it activates before use. Once activated, the barrier reaches approximately $3.5 \mathrm{in}$. high. The absorbed water turns into a gel inside the barriers. The Quick Dams were evaluated saturated and unsaturated. Figure 23 shows the Quick Dam before saturation.

Figure 23. Unsaturated Quick Dam Expanding Barrier.

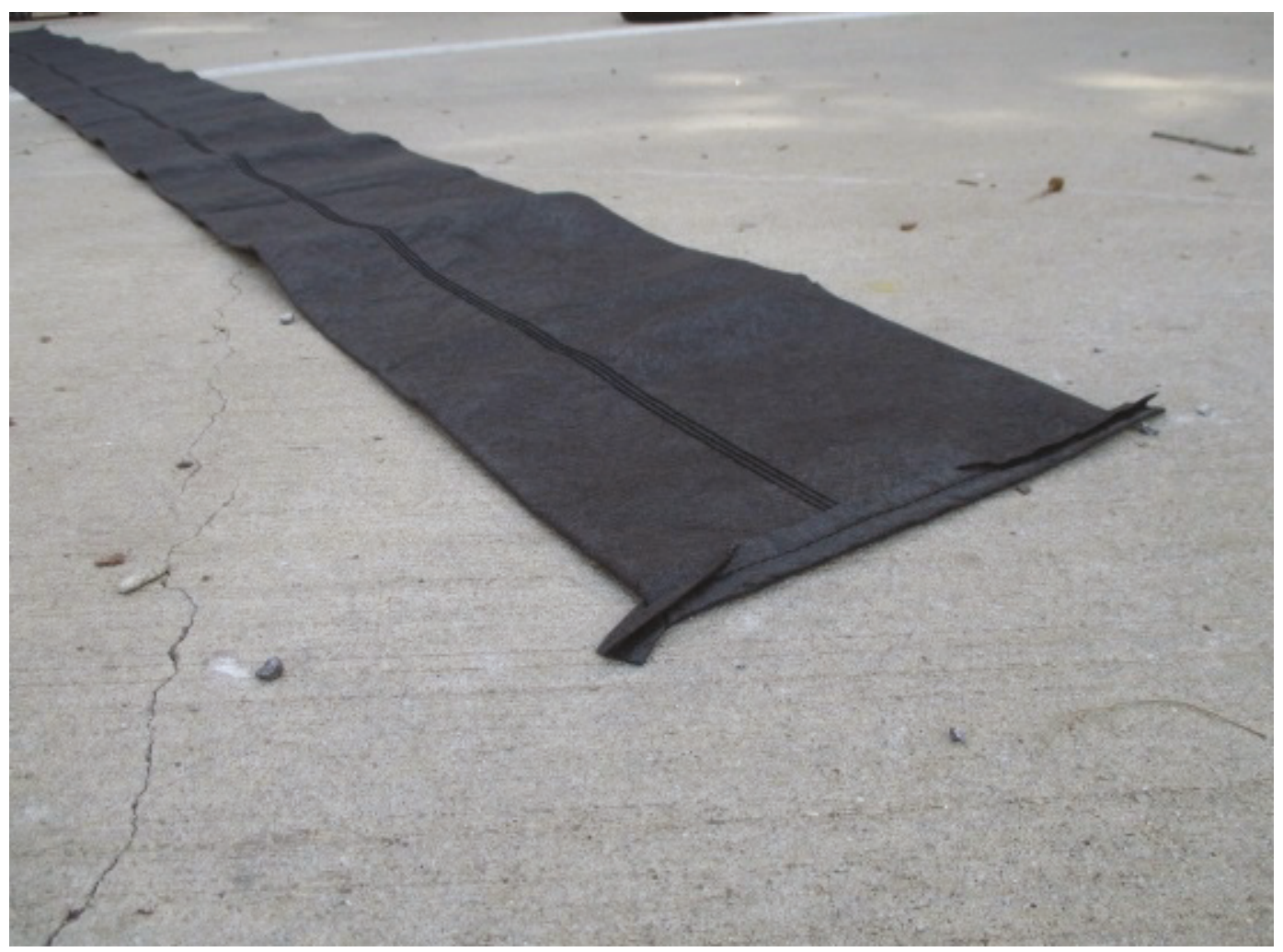




\section{Field Evaluation and Results}

\subsection{Grooved pavement}

The tests conducted on the grooved pavements took place during December 2016 under cloudy skies. The air temperatures ranged from 45 to $49^{\circ} \mathrm{F}$ with a 7 -mph wind blowing from the northwest. The humidity averaged $87 \%$.

The sprinkler head mounted in the middle of the top of the rain system was turned off due to excessive simulated rainfall, so four sprinkler heads mounted on the corners were used to simulate an even rainfall. One rain gauge was mounted on the rain system, and four rain gauges were placed under the rain system inside traffic cones, as shown in Figure 24. For each test, the rain system ran for $15 \mathrm{~min}$. The flow meter gauge was set to $4.5 \mathrm{gal} / \mathrm{min}$, which produced precipitation of approximately $1 \mathrm{in} . / \mathrm{hr}$. Specific details regarding the rain gauge readings are presented with each test in the following sections.

Figure 24. Rain gauges mounted on the rain system and inside cones.

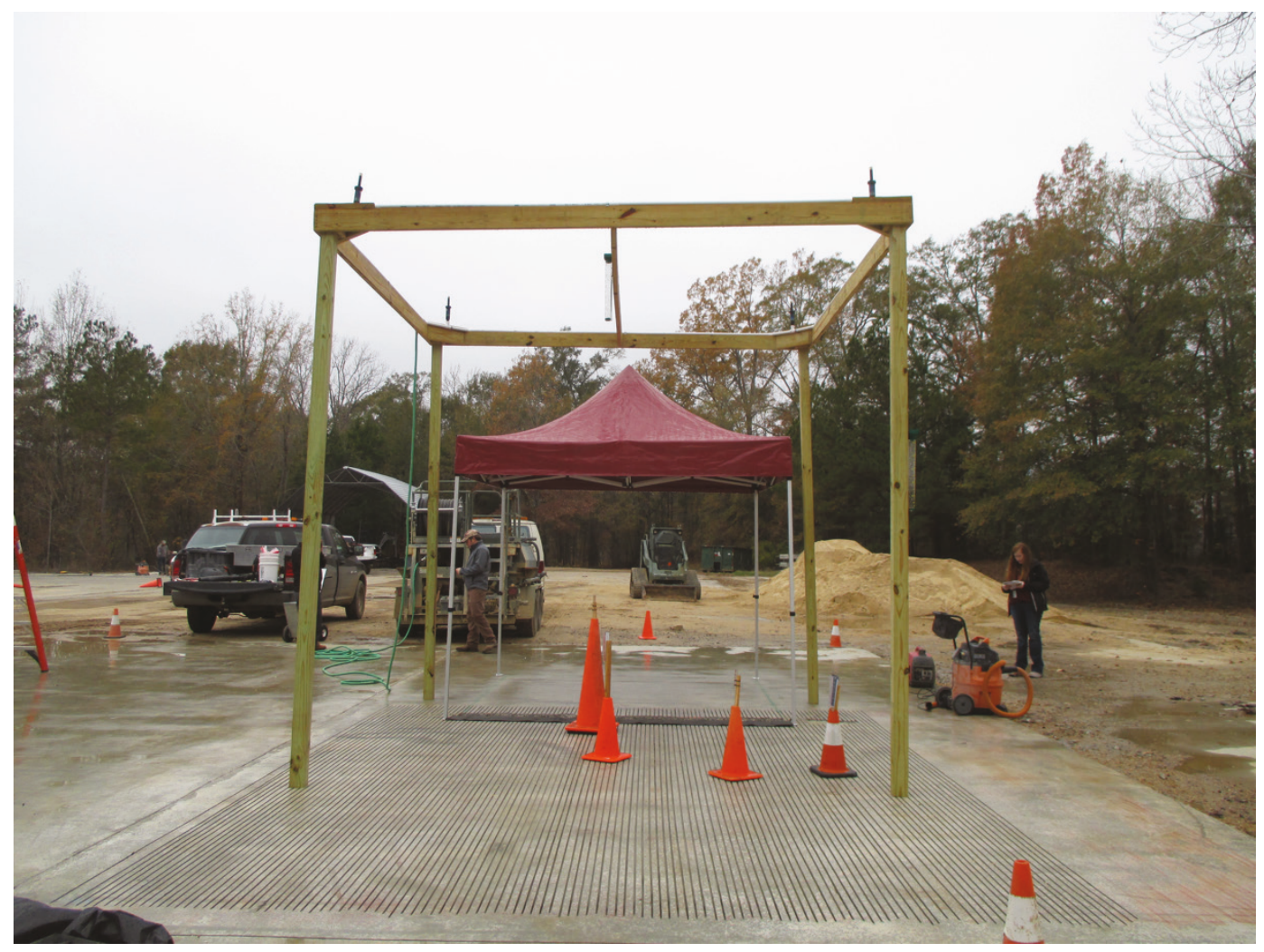


The water catch basin cut into the grooved pavement was $9.5 \mathrm{ft}$ long, 6 in. wide, and 5 in. deep ( $2 \mathrm{ft} 3$ ). The water depth after each test was measured at the same three quarter points along the length of the basin, and the average volume of water collected in the basin was calculated. After each test, all of the rainwater was vacuumed out of the basin and blown out of the grooves, as shown in Figures 25 and 26, respectively. Also, the water remaining on top of the tent was removed after each test.

All water barriers were placed on the high side of the catch basin so that the water would flow into the barrier that was positioned on the edge of the basin. Two of the legs on the pop-up tent used for each evaluated barrier were placed just on the outside of the basin. This simulated the location of a 10-ft-by-10-ft pop-up tent over an 8.5-ft-by-8.5-ft crater.

Figure 25. Vacuuming water out of the basin.

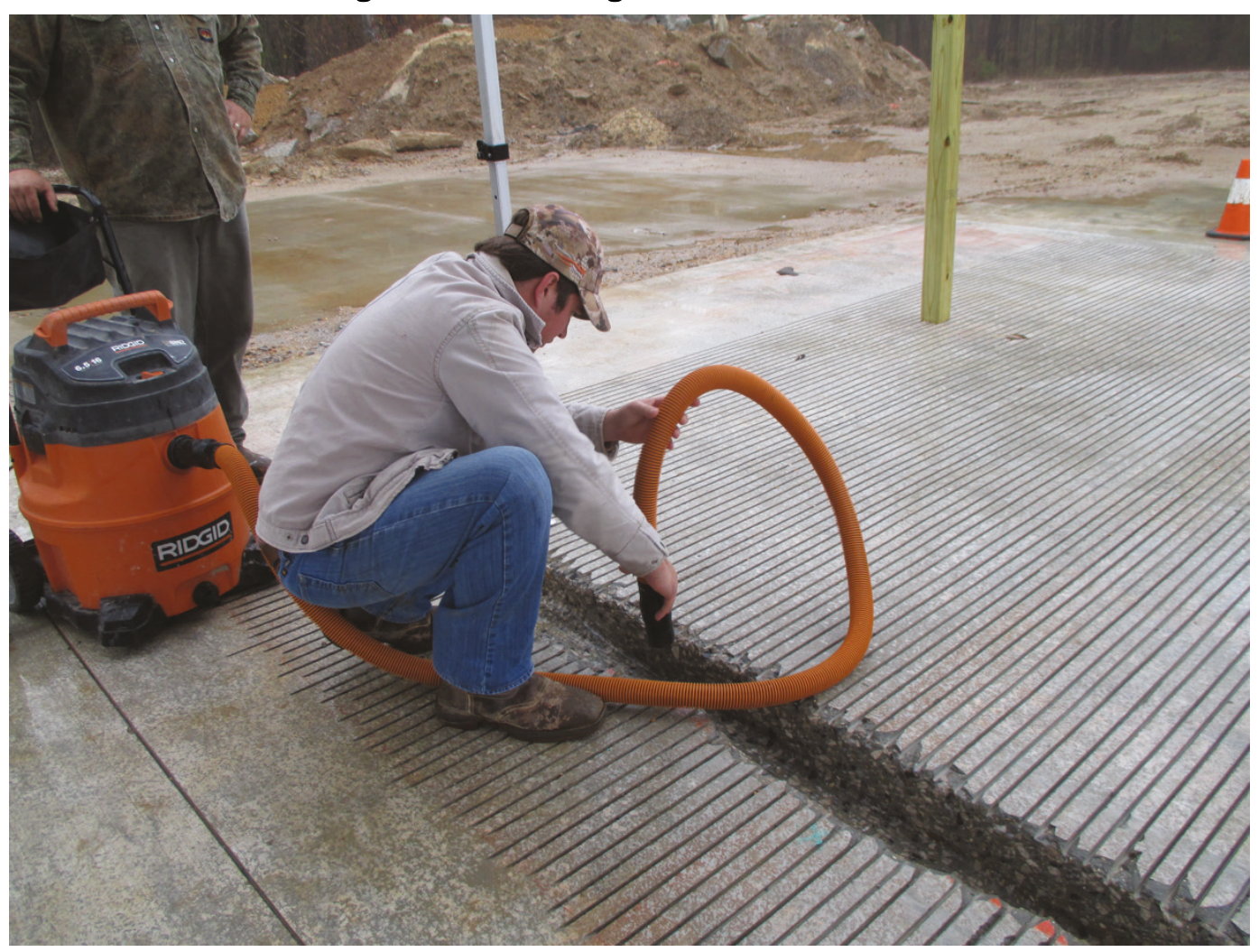


Figure 26. Blowing water out of pavement grooves between tests.

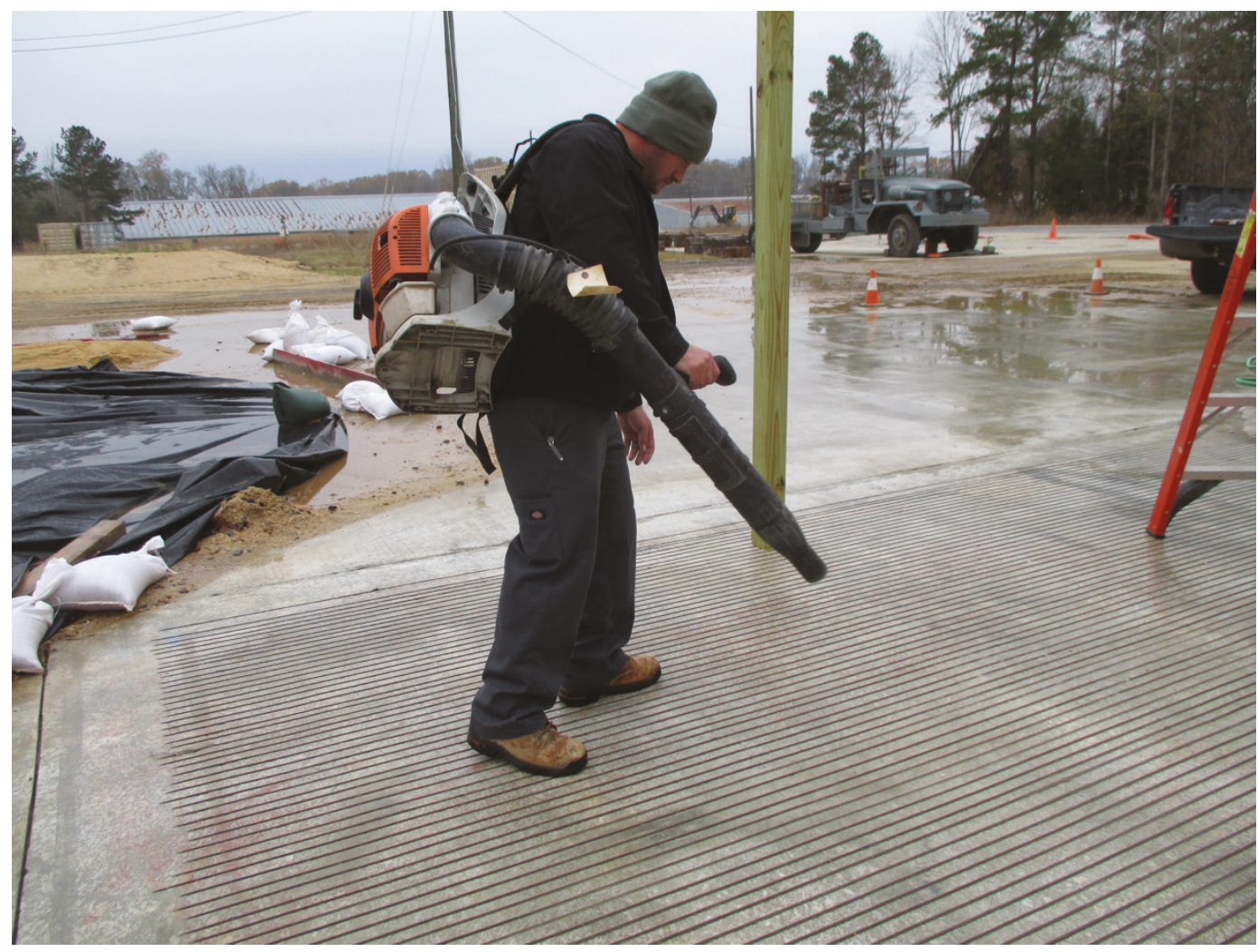

\subsubsection{Quick Dam Expanding Barrier - unsaturated}

The first water barrier evaluation on the grooved pavements was the unsaturated Quick Dam Expanding Barrier (Figure 27); the 10-ft-long Quick Dam was used directly out of the package according to manufacturer instructions. The Quick Dam was not able to completely conform to the pavement nor block the pavement grooves. Also, water runoff from the tent caused one portion of the Quick Dam to activate more quickly than the rest of the barrier, as shown in Figure 28. The early activation did not seem to affect the water barrier, however. The basin was full of water after $13 \mathrm{~min}$. The rain continued for another $2 \mathrm{~min}$, and the measured rainfall averaged 0.19 in. 
Figure 27. Unsaturated Quick Dam before evaluation.

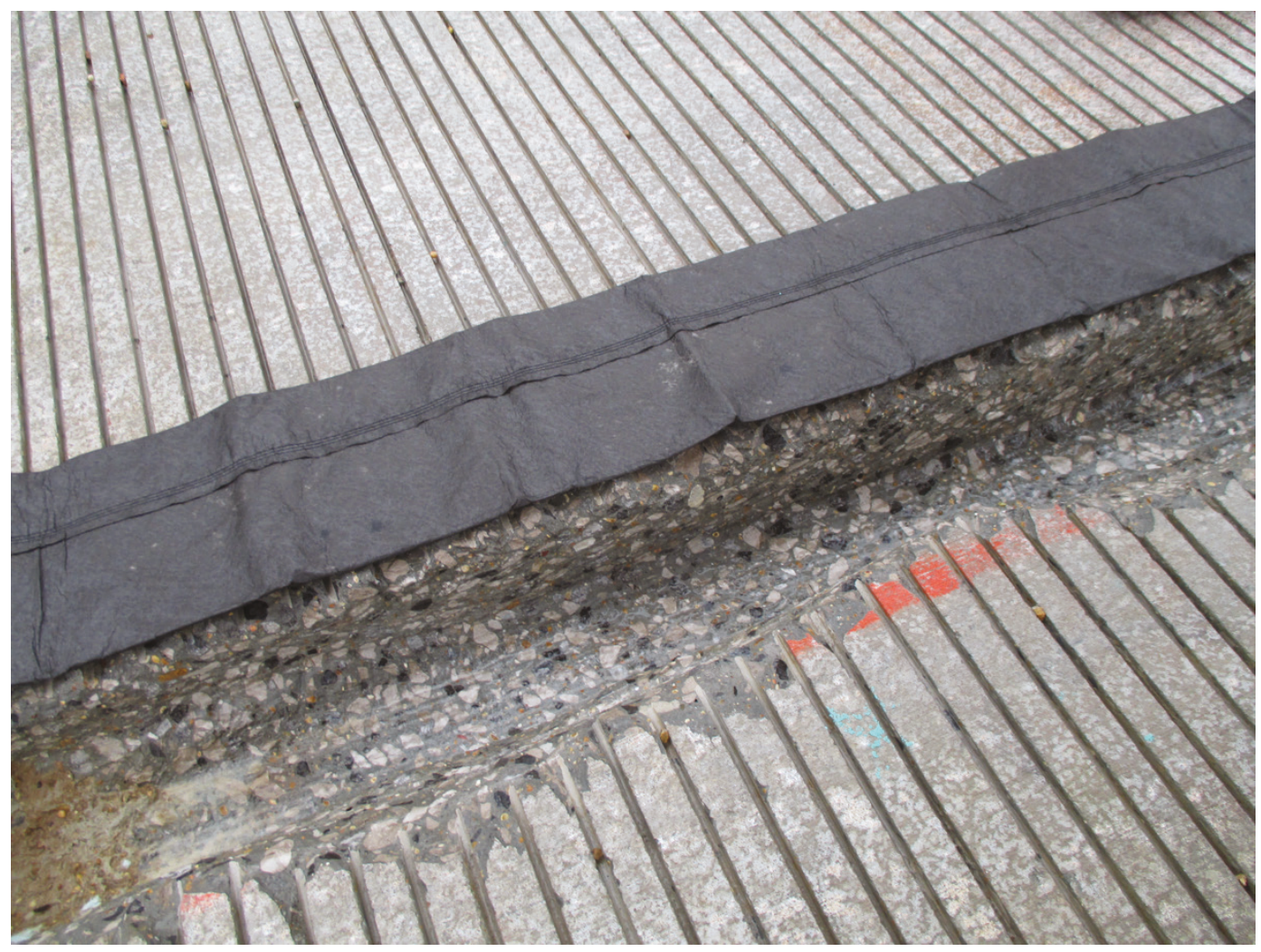

Figure 28. Quick Dam activated in the middle from tent water runoff.

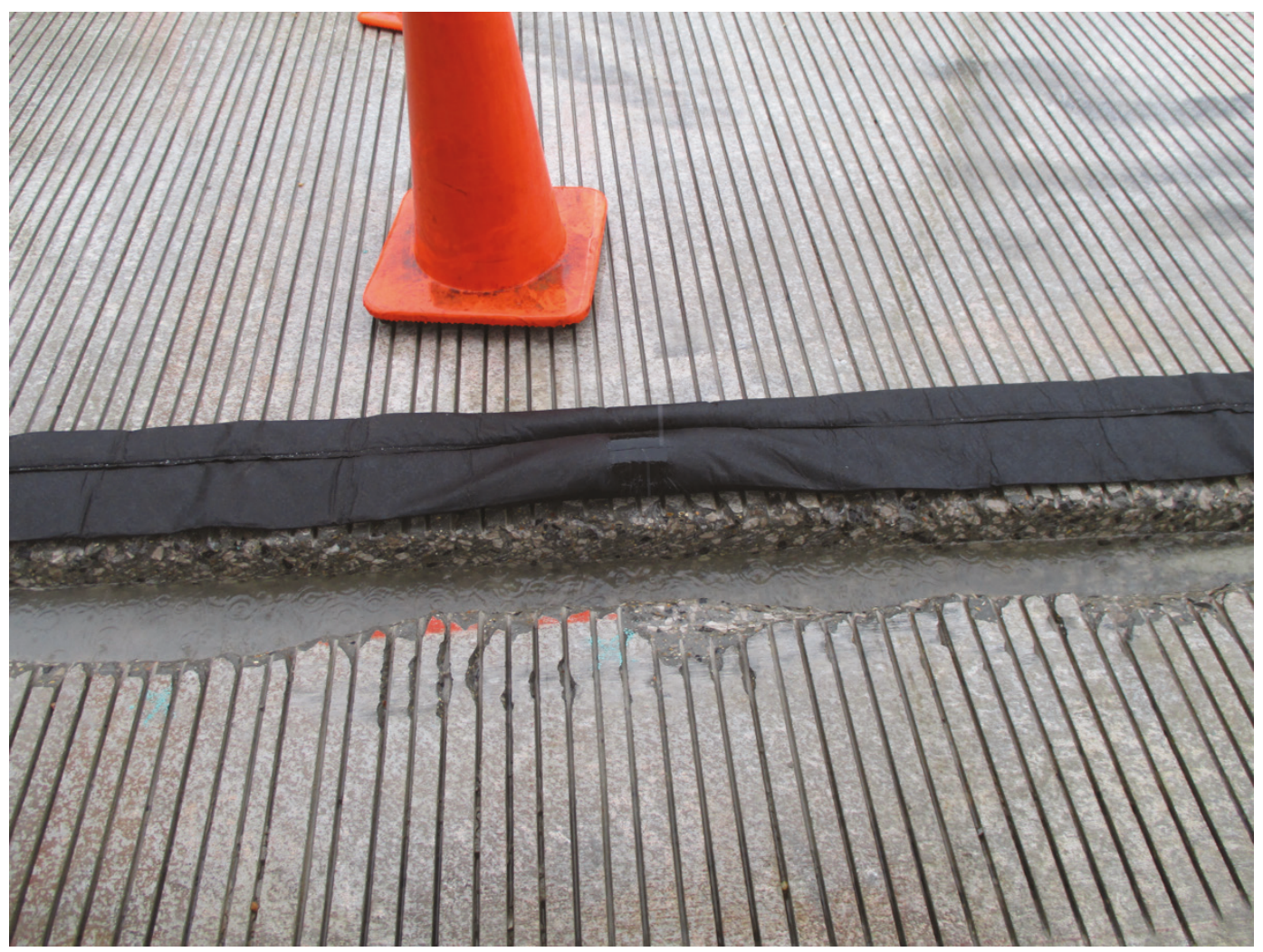




\subsubsection{Quick Dam Expanding Barrier - saturated}

A Quick Dam Expanding Barrier was entirely submerged in water for complete activation before the start of its evaluation. Figure 29 shows the saturated Quick Dam ready for evaluation. Three minutes after the rain system started, an unsaturated 10-ft-long Quick Dam was added to the north end of the basin (Figure 30); the activated Quick Dam shortened the barrier so that it was only 1 in. past the length of the basin, allowing water to enter the basin from the side. The saturated Quick Dam helped with tent water runoff, but it was not effective for blocking water in the pavement grooves. The basin was full after 11 min of rainfall. The unsaturated Quick Dam was slightly more effective than the saturated Quick Dam. After $15 \mathrm{~min}$, the average rainfall was $0.17 \mathrm{in}$.

Figure 29. Saturated Quick Dam before testing.

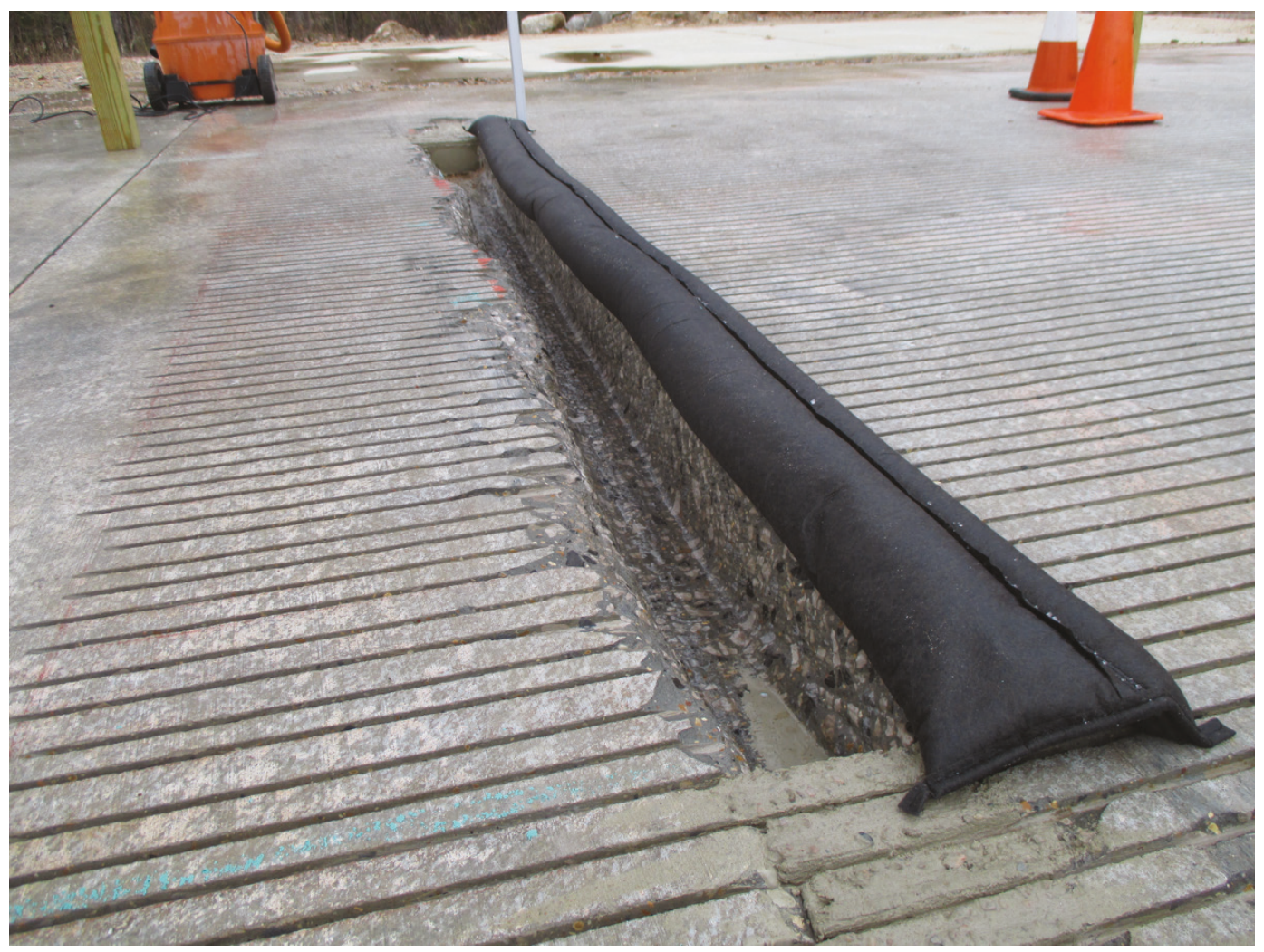


Figure 30. Unsaturated Quick Dam added to north end.

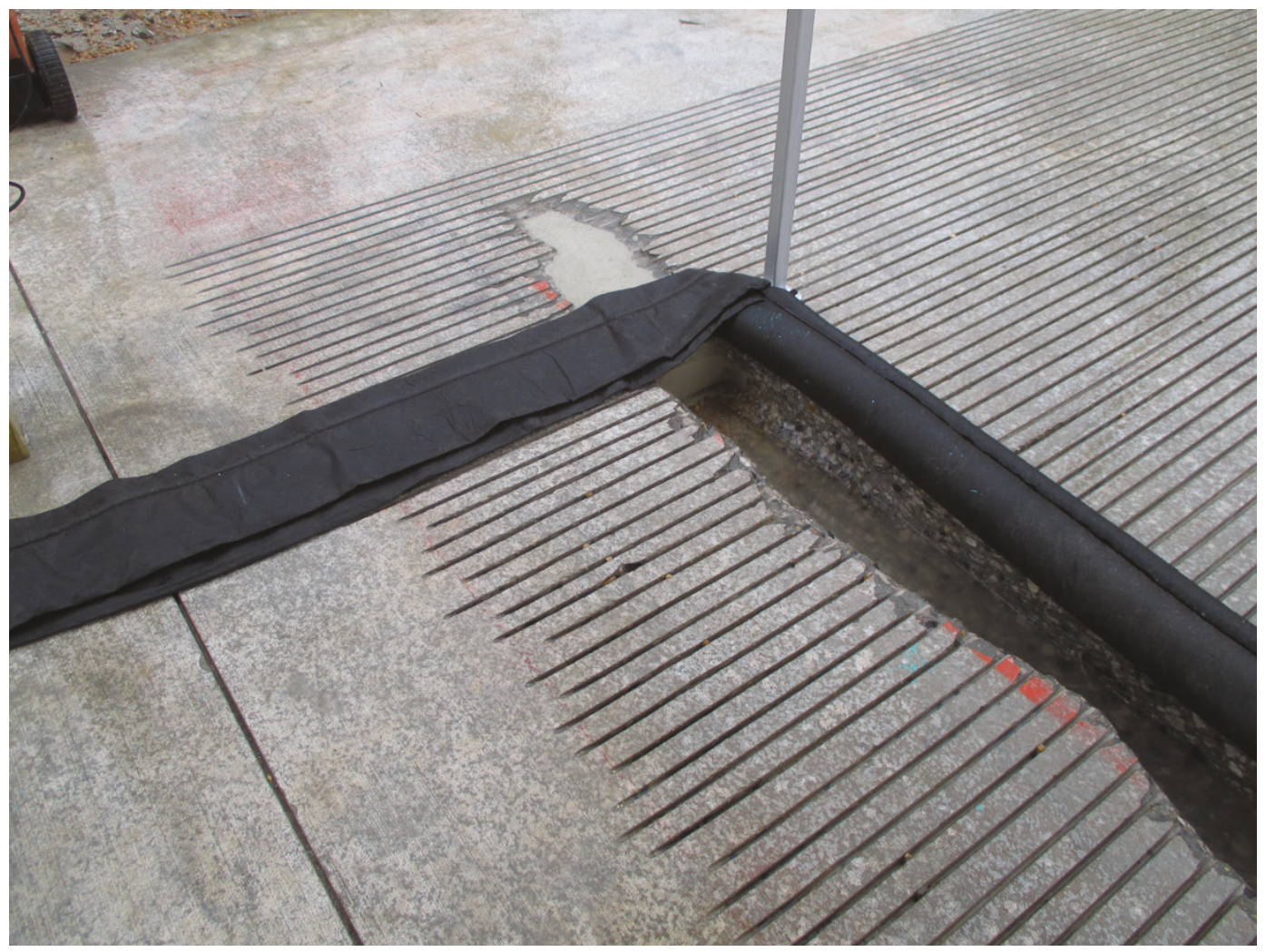

\subsubsection{Containment dike}

Two containment dikes were set up to mitigate water flowing into the catch basin and tent water runoff on the north end of the basin, as shown in Figure 31. The containment dikes were not effective on the grooved pavements because of their inability to block the water in the grooves. The rainwater immediately began flowing into the basin. Figure 32 shows the rainwater trickling under the containment dike and into the basin. The basin was full of water after 10 min (Figure 33). The measured rainfall, after 15 min, averaged 0.20 in. 
Figure 31. Containment dikes protecting the basin from rain.

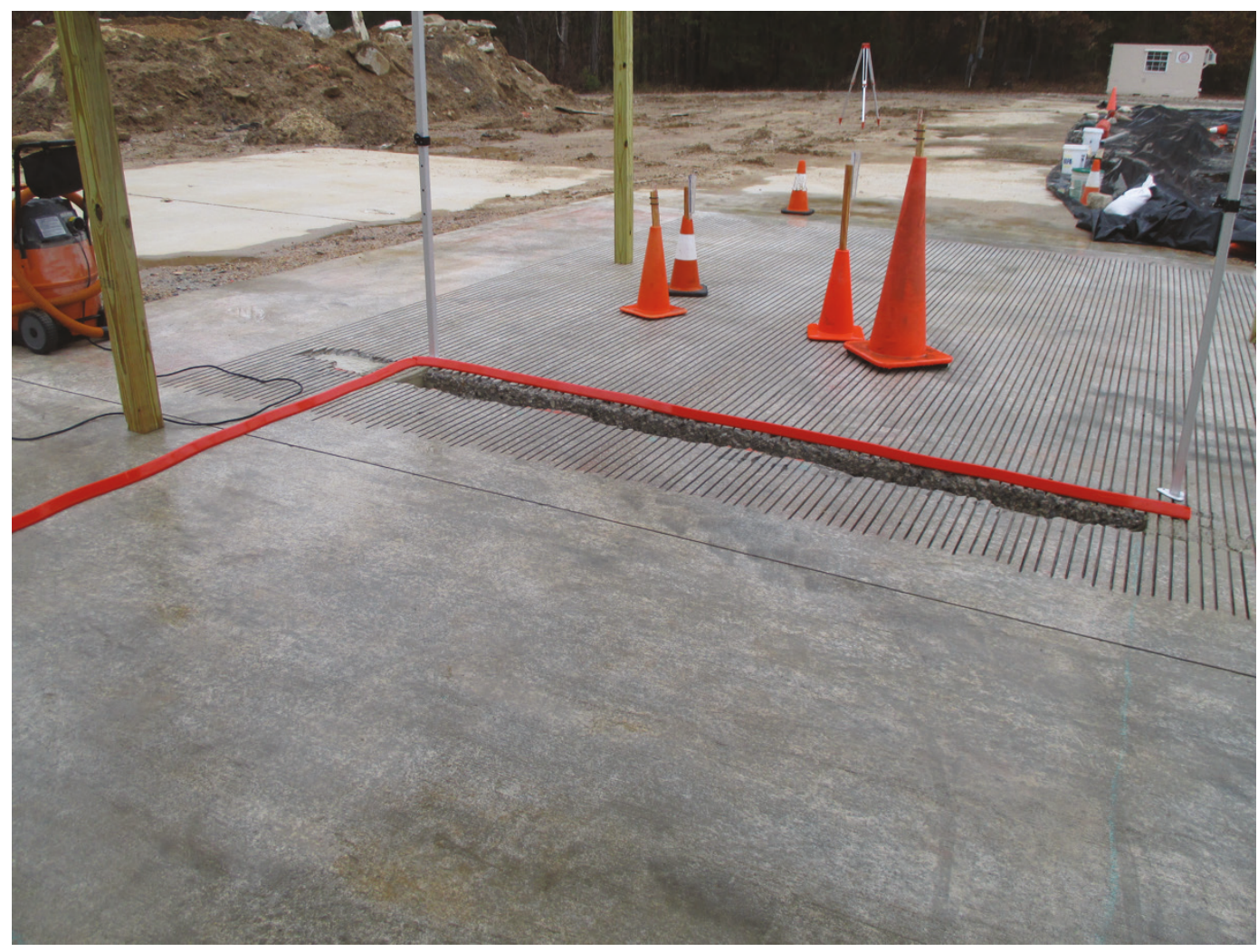

Figure 32. Rainwater flowing under the containment dike.

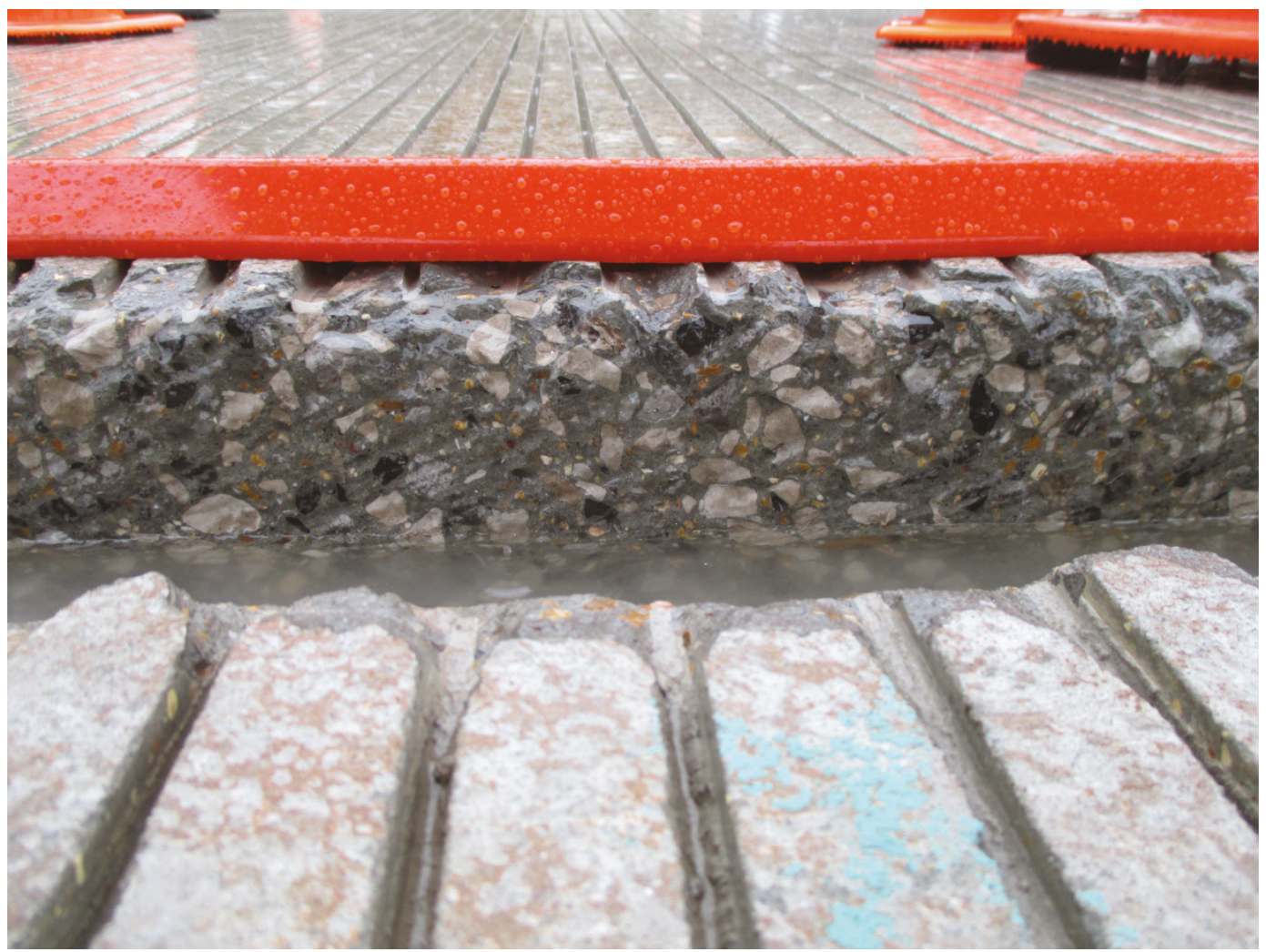


Figure 33. Full basin after $10 \mathrm{~min}$ of rain.

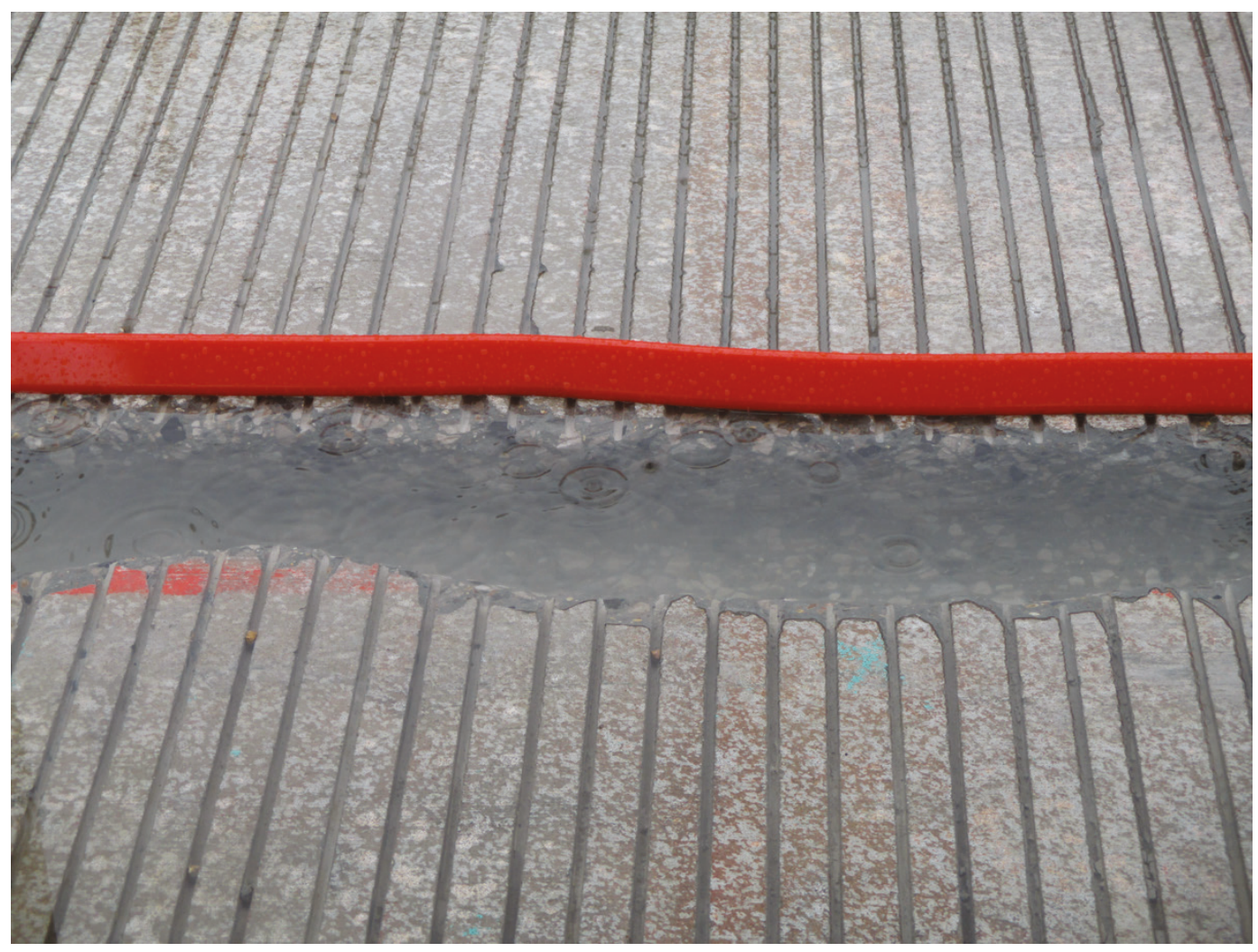

\subsubsection{Fire hose}

The middle section of a 30 -ft-long fire hose partially filled with water was placed along the edge of the catch basin with the ends stretching along the north and south, as shown in Figure 34. The fire hose, similar to the containment dike, was unable to block the grooves from water flowing into the basin (Figure 35). The fire hose was also heavy and difficult to maneuver. The basin was full of water after $11 \mathrm{~min}$. The rain continued for another $4 \mathrm{~min}$, averaging $0.23 \mathrm{in}$., as measured from the rain gauges after testing.

\subsubsection{Tarp}

The edge of the polyvinyl tarp was placed $4.5 \mathrm{ft}$ off the basin. The pop-up tent was placed on top of the tarp. Figure 36 shows the setup before testing began. The tarp was extremely effective for preventing tent runoff into the basin, as shown in Figure 37. The tarp was carefully removed after 15 min of rainfall; the basin was full of water. No water was in the pavement grooves on the back side of the basin, so it was assumed that the basin filled up at $15 \mathrm{~min}$. The average rainfall measured during this evaluation was $0.21 \mathrm{in}$. 
Figure 34. Capped and plugged fire hose partially filled with water.

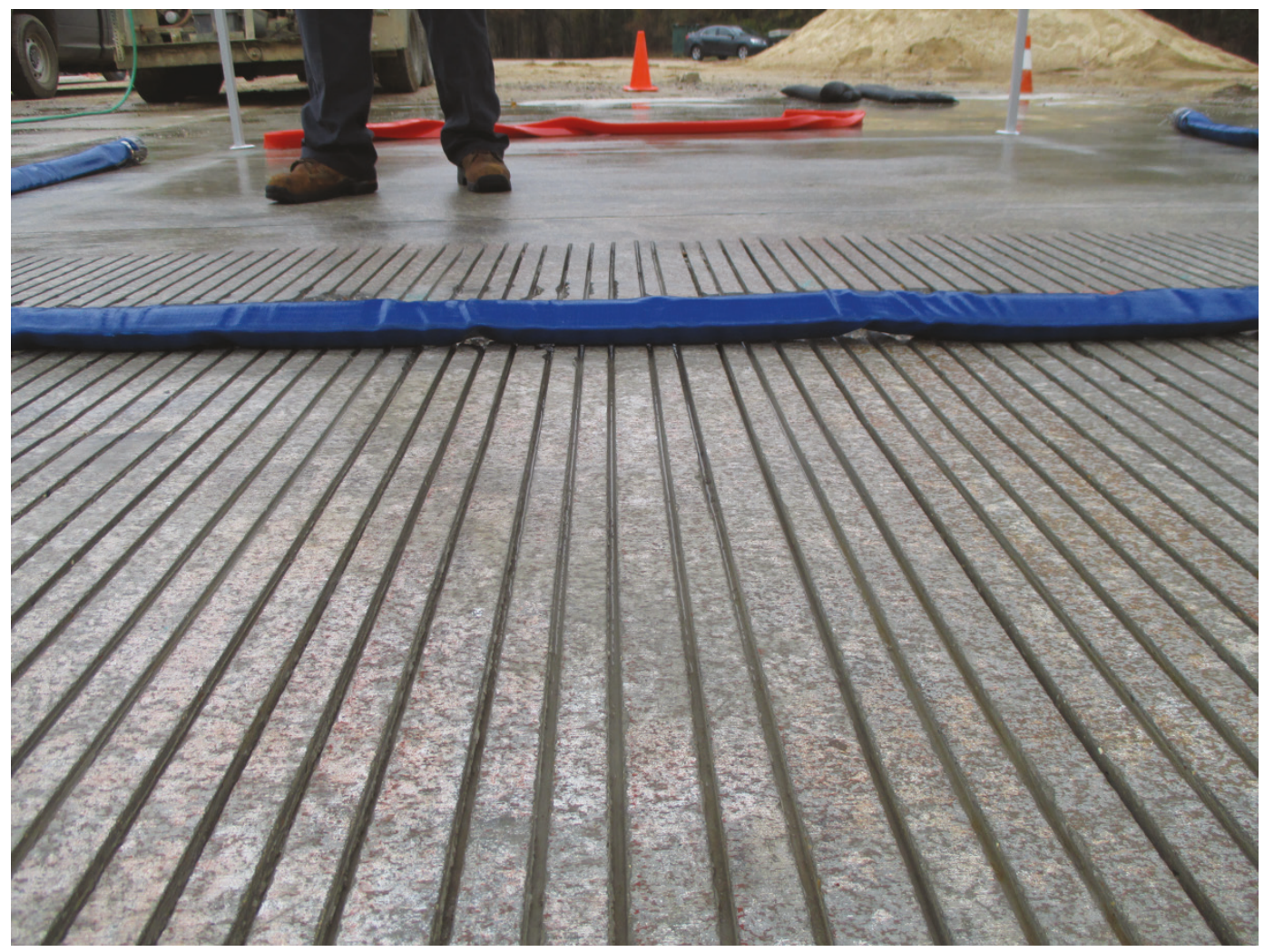

Figure 35. Fire hose not conforming to pavement.

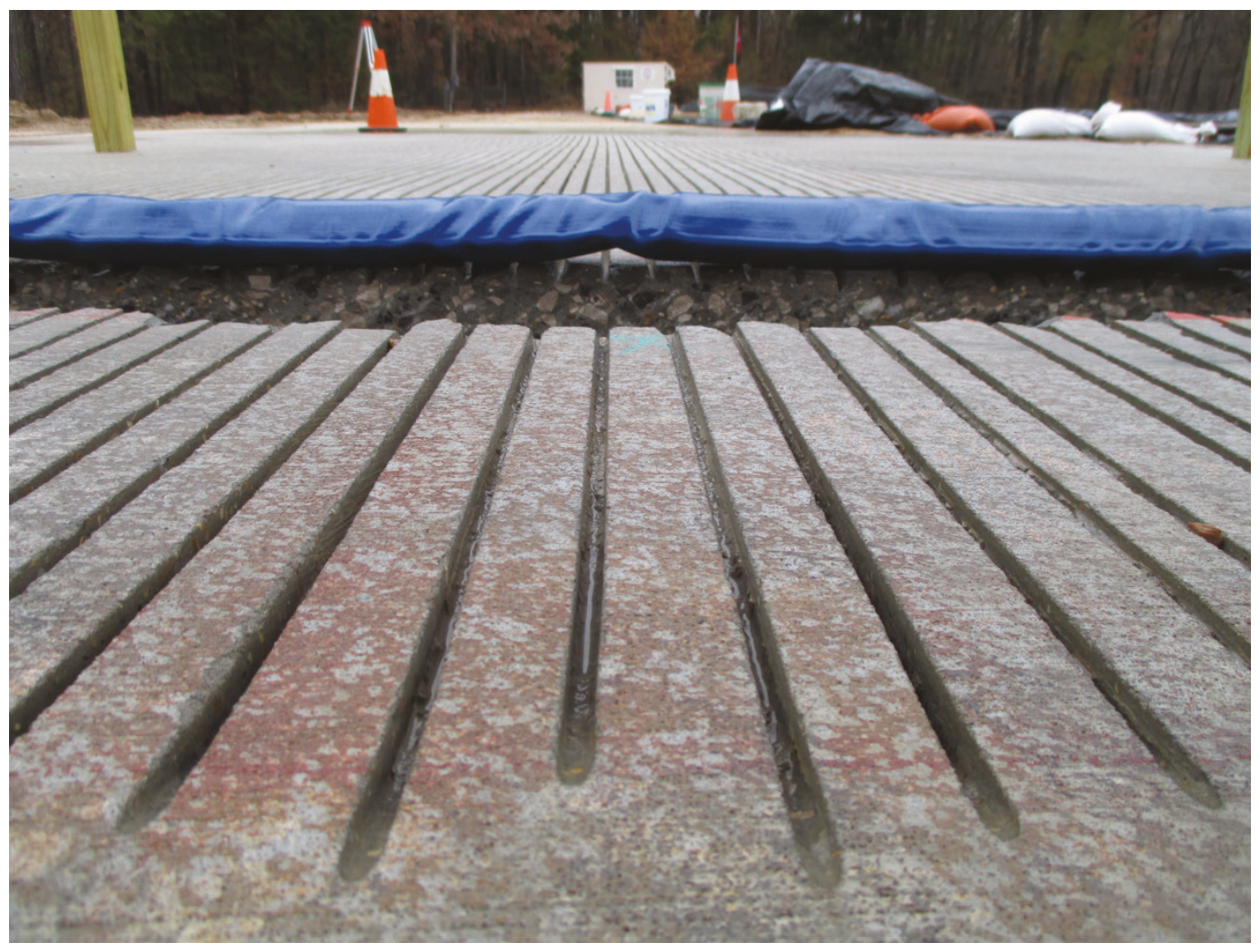


Figure 36. Tarp before evaluation.

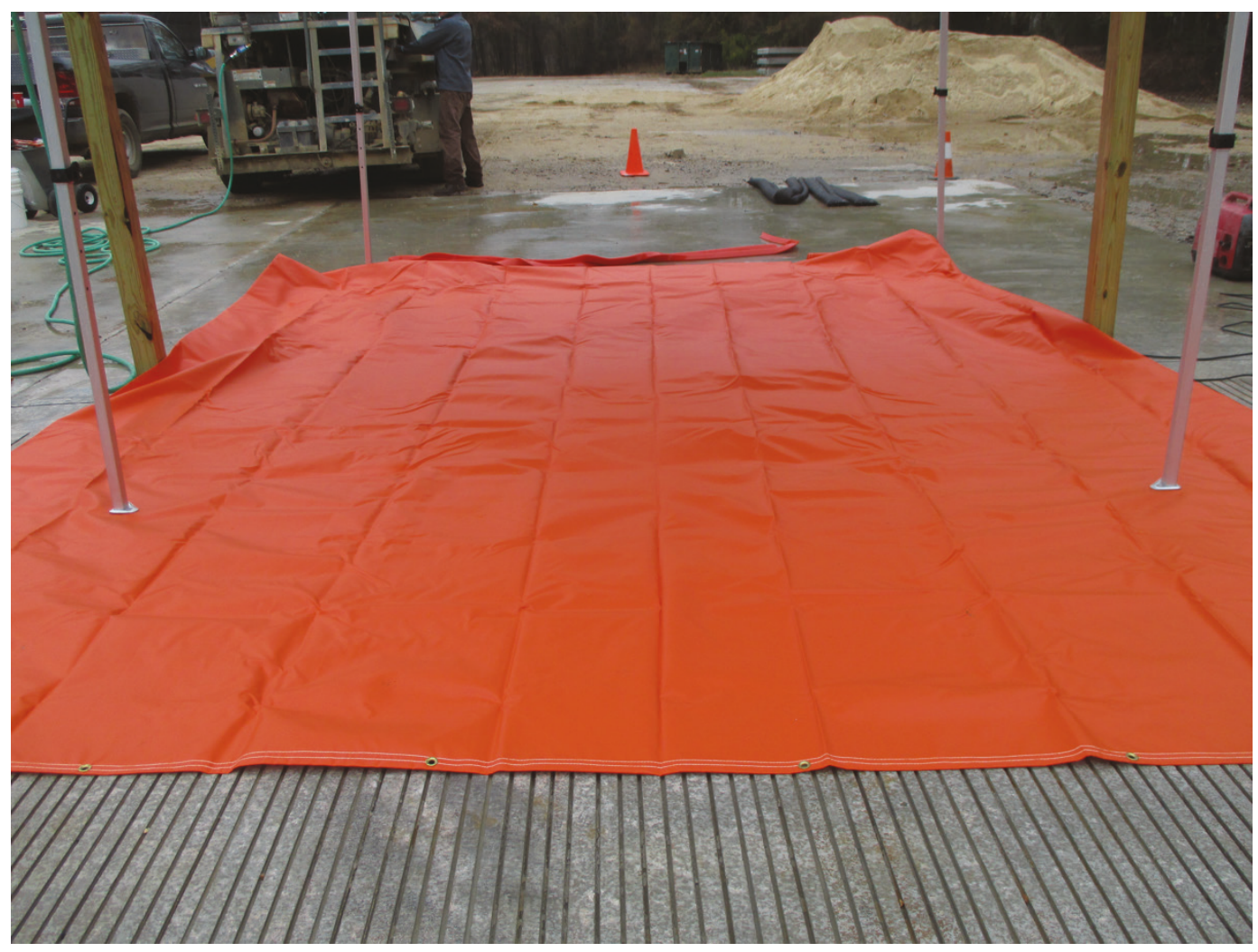

Figure 37. Tent water runoff pooled on top of tarp.

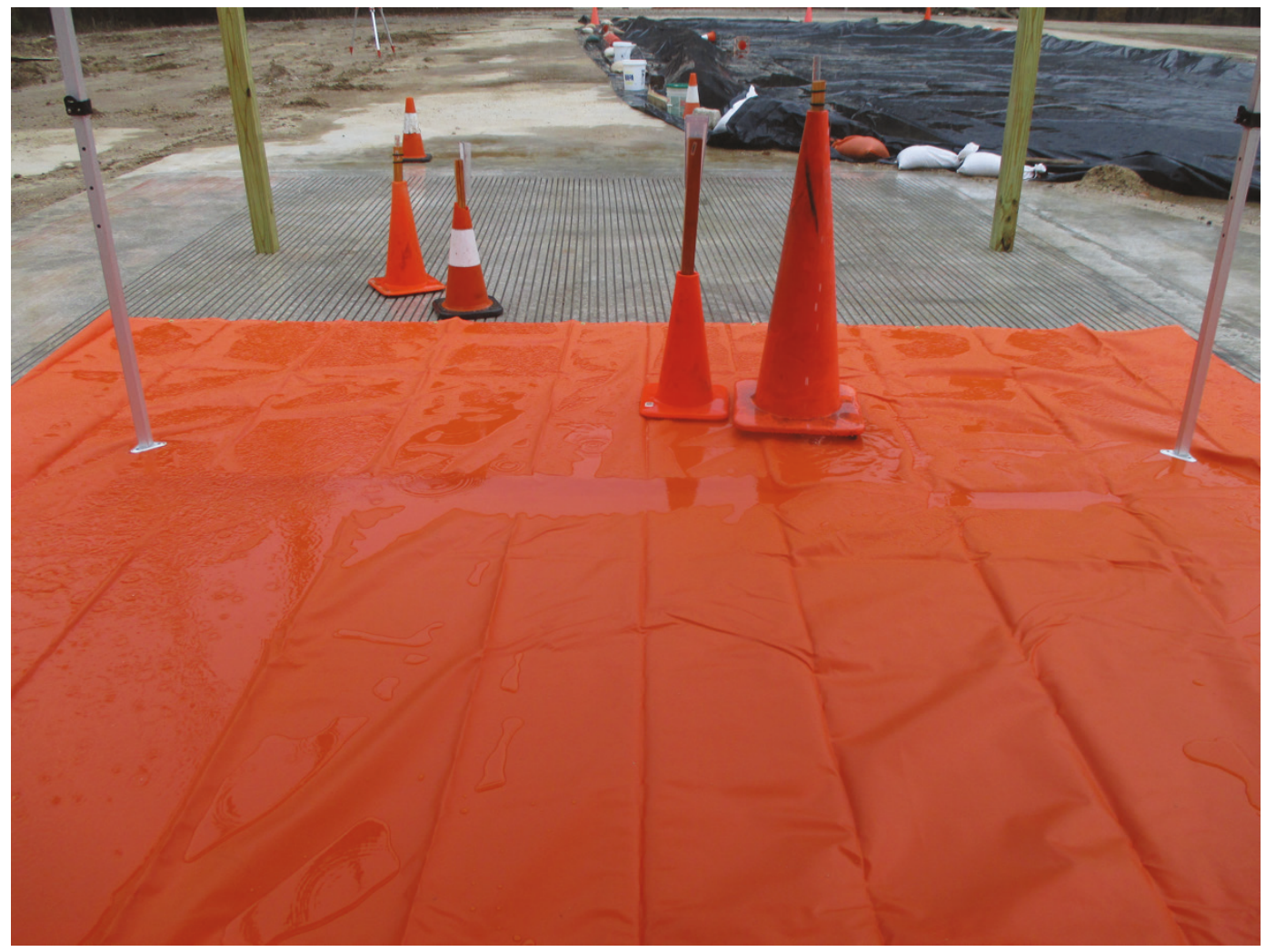




\subsubsection{Tarp, fire hose, and sand berm}

A polyvinyl tarp, a capped and plugged fire hose partially filled with water, and sand were used in conjunction to form a barrier for prohibiting the rainwater from entering the catch basin. This barrier had previously been successfully tested on smooth concrete pavements (Pullen et al. 2014).

One edge of the tarp was placed $3 \mathrm{ft}$ off the edge of the catch basin. The fire hose was positioned on the inside edge of the tarp, and sand was placed along the edge of the tarp and fire hose by using a hand scoop, as shown in Figure 38. It took $1 \mathrm{~min} 40 \mathrm{sec}$ to place the sand along the edge by using the hand scoop. Approximately 4 gal of sand (3.5\% moisture) was used. After placement, the sand was compacted by a technician stepping along the top and edge of the berm (Figure 39). The sand berm was approximately 1 to 1.5 in. high after the boot compaction.

Figure 38. Placing sand along the edge of the tarp and fire hose.

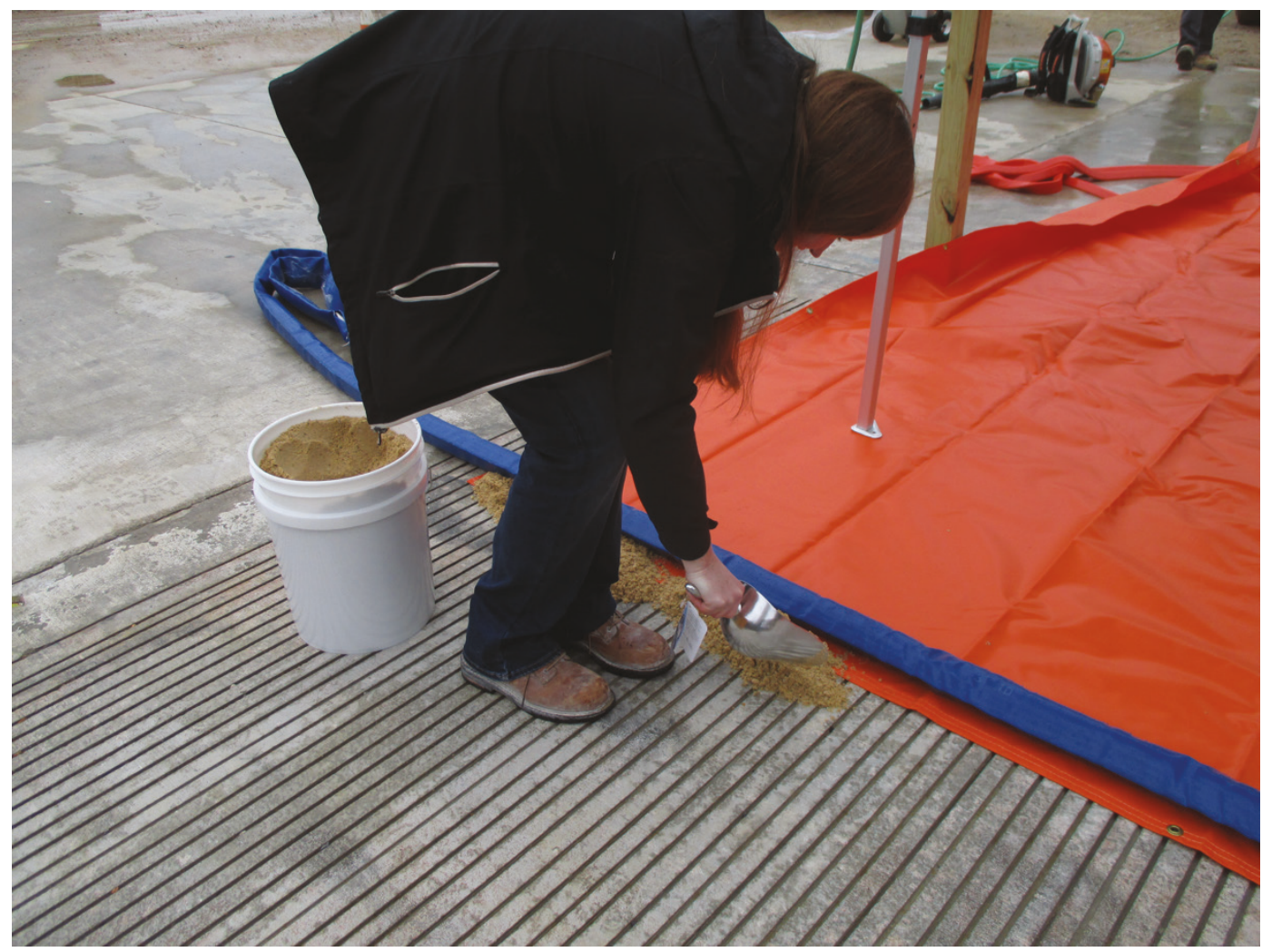


Figure 39. Compacting sand.

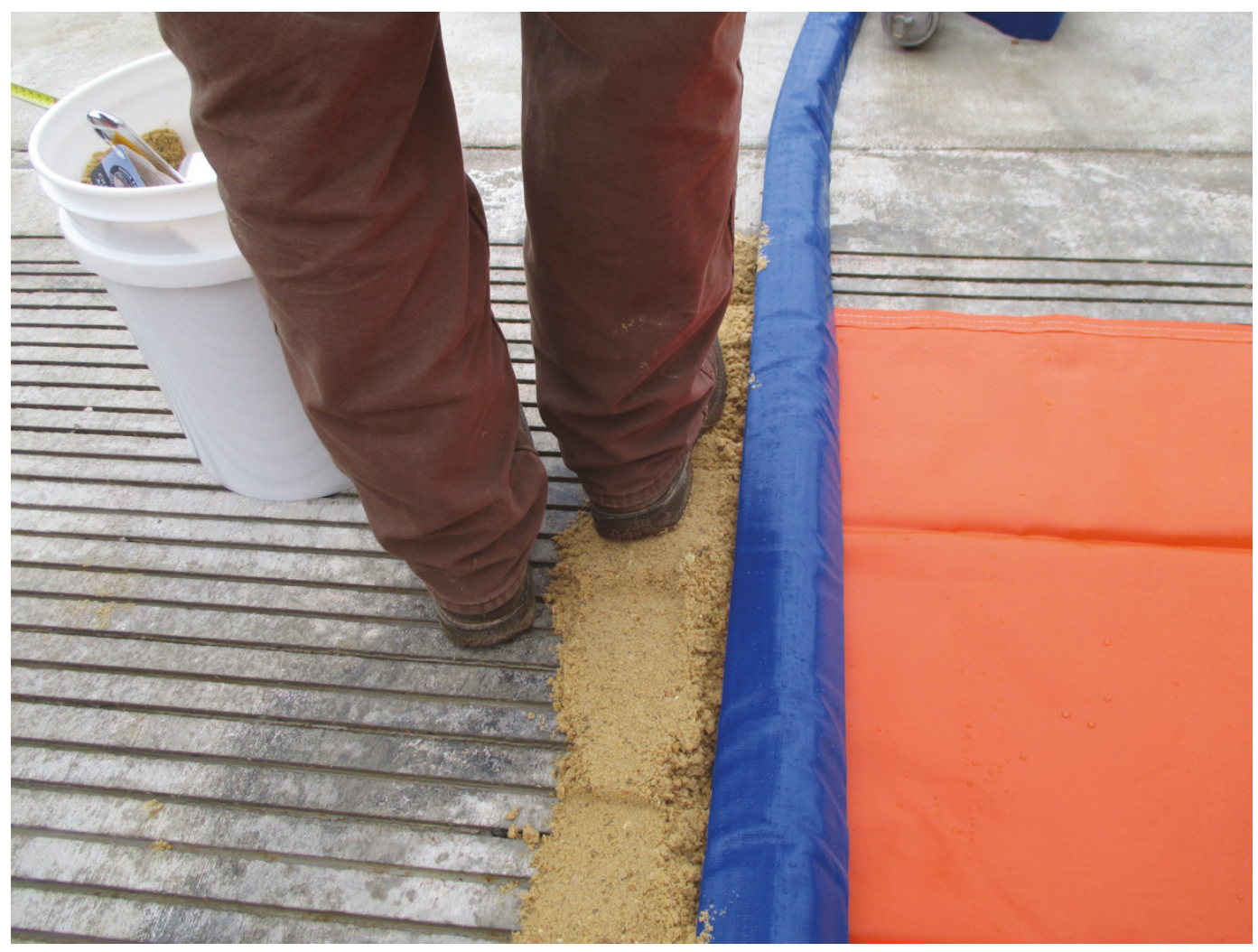

The combination barrier was successful at preventing most of the water from entering the basin. Figure 40 shows the barrier during the evaluation, and Figure 41 show the rainwater pooled by the sand berm. The tarp was effective for stopping tent runoff water from entering the basin. It was assumed that the fire hose contributed little, considering that when acting alone, the fire hose barrier was not effective for preventing infilatration of water into the basin, as discussed in Section 4.1.4.

The tarp and fire hose were carefully removed after 15 min of evaluating the combination water barrier. Figure 42 shows the water pooled by the sand berm on what had been the exposed side of the slab and dry pavement on what had been the tarp-covered side. The sand berm was effective for preventing water from entering the basin through the pavement grooves, and the tarp prevented any tent runoff water from entering the basin. The average rainfall collected in the rain gauges was 0.24 in. Figure 43 shows the water depth being measured at one of the quarter points. The volume of water collected in the basin was calculated to be approximately $0.68 \mathrm{ft} 3$. 
Figure 40. Barrier during evaluation.

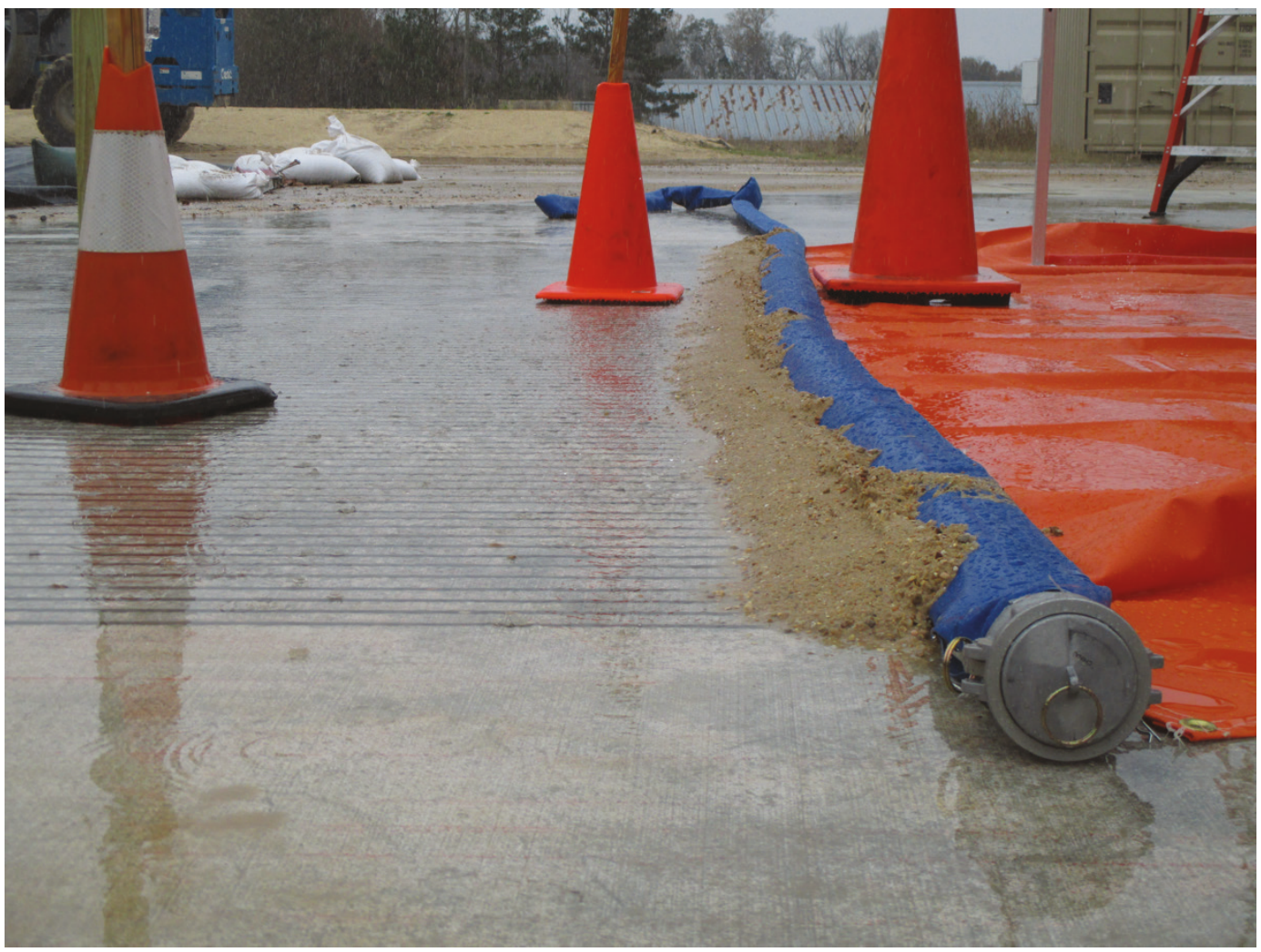

Figure 41. Rainwater pooling by sand berm.

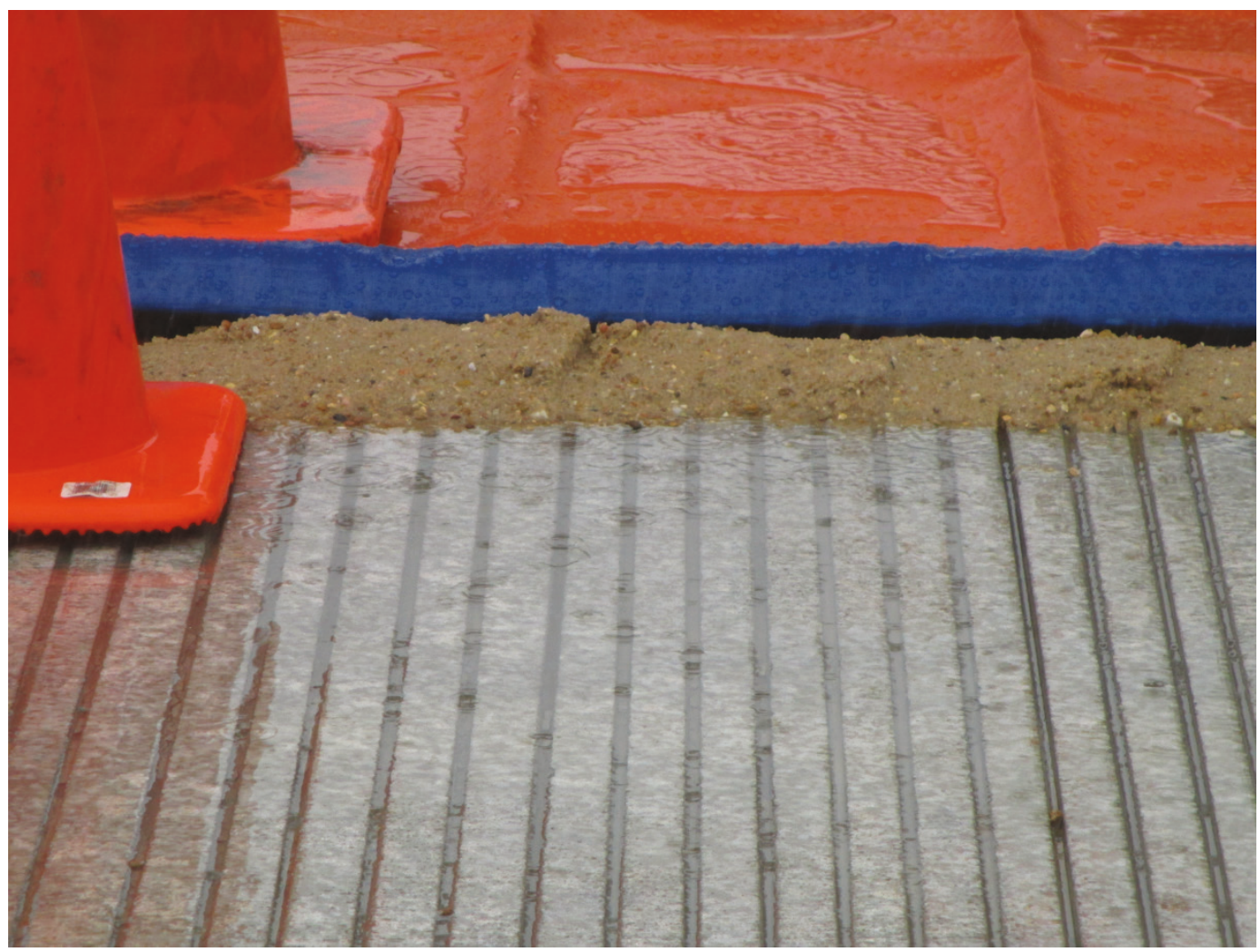


Figure 42. Sand berm remaining after the removal of tarp and fire hose.

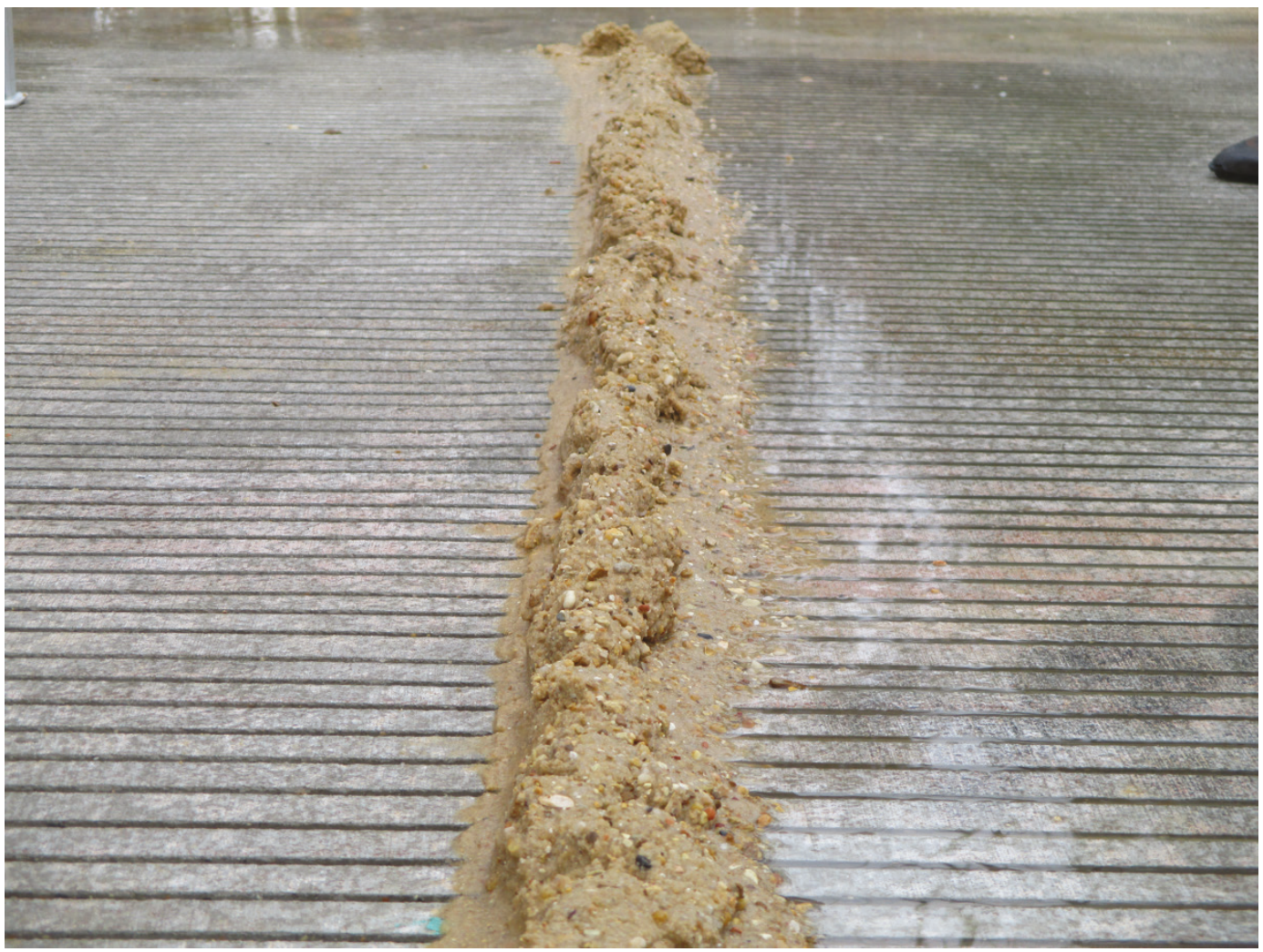

Figure 43. Measuring water depth in the basin at a quarter point.

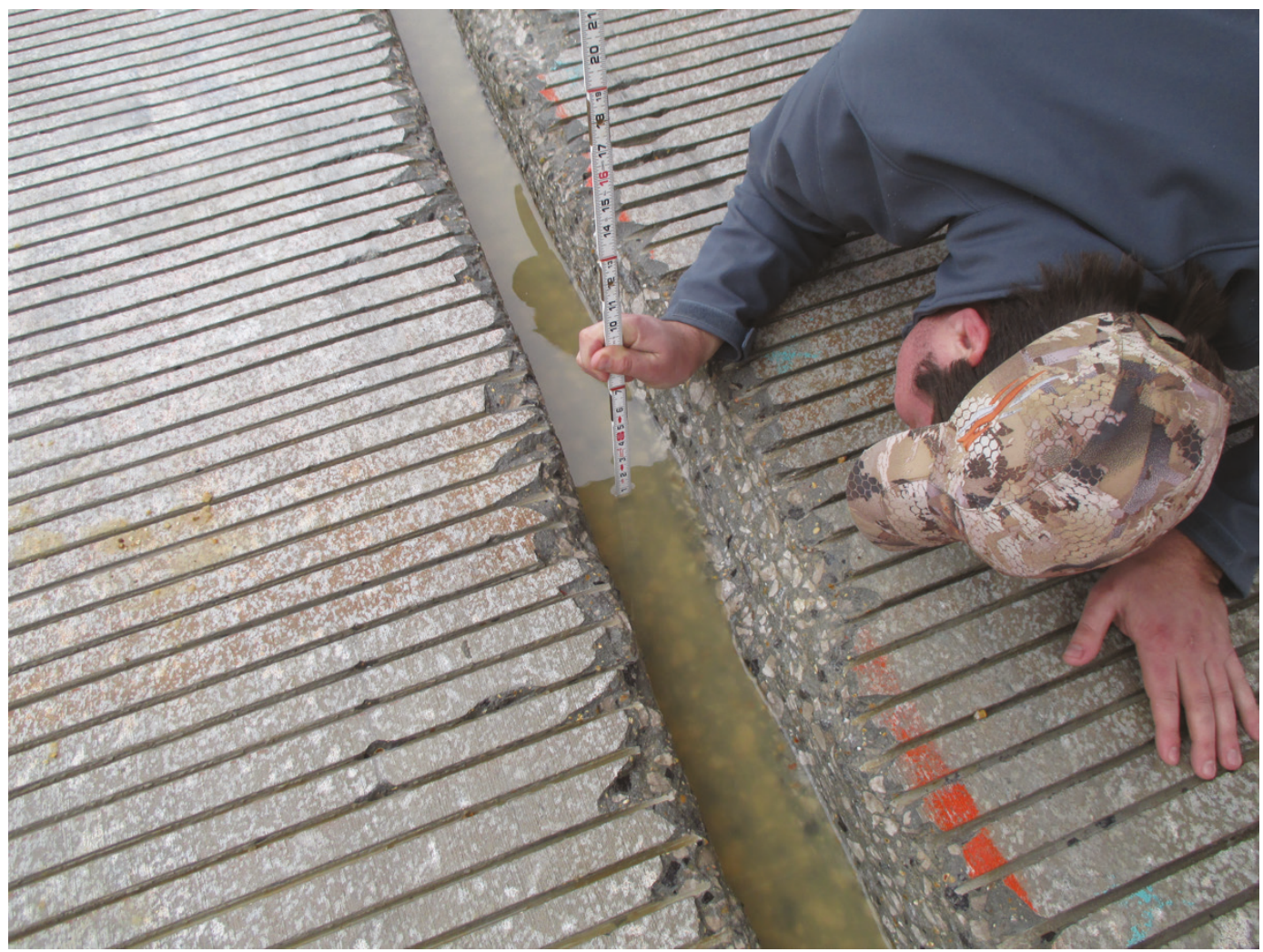




\subsubsection{Sand}

For this evaluation, an approximately 6-in.-wide sand berm was placed approximately $4 \mathrm{in}$. from the high side of the water catch basin and outside the tent legs. The moisture of the sand was determined to be $3.5 \%$. The sand was placed by using a hand scoop, as shown in Figure 44, and compacted, as shown in Figure 45. The compaction forced the sand to be pressed into the pavement grooves. The overall view of the test in progress is shown in Figure 46.

One section of the tent produced a steady trickle of rainwater that fell onto the sand barrier. This caused the compacted sand to loosen, as shown in Figure 47. Figure 47 also shows the water pooling along the high side of the sand berm, indicating that the barrier was effective for prohibiting much of the rainwater from entering the basin. After 15 min of an average of 0.29 in. of rainfall, as measured with the rain gauges, the $2-\mathrm{ft} 3$ basin collected $0.68 \mathrm{ft}^{3}$ of the precipitation (Figure 48 ).

Figure 44. Distributing sand onto the grooved pavement.

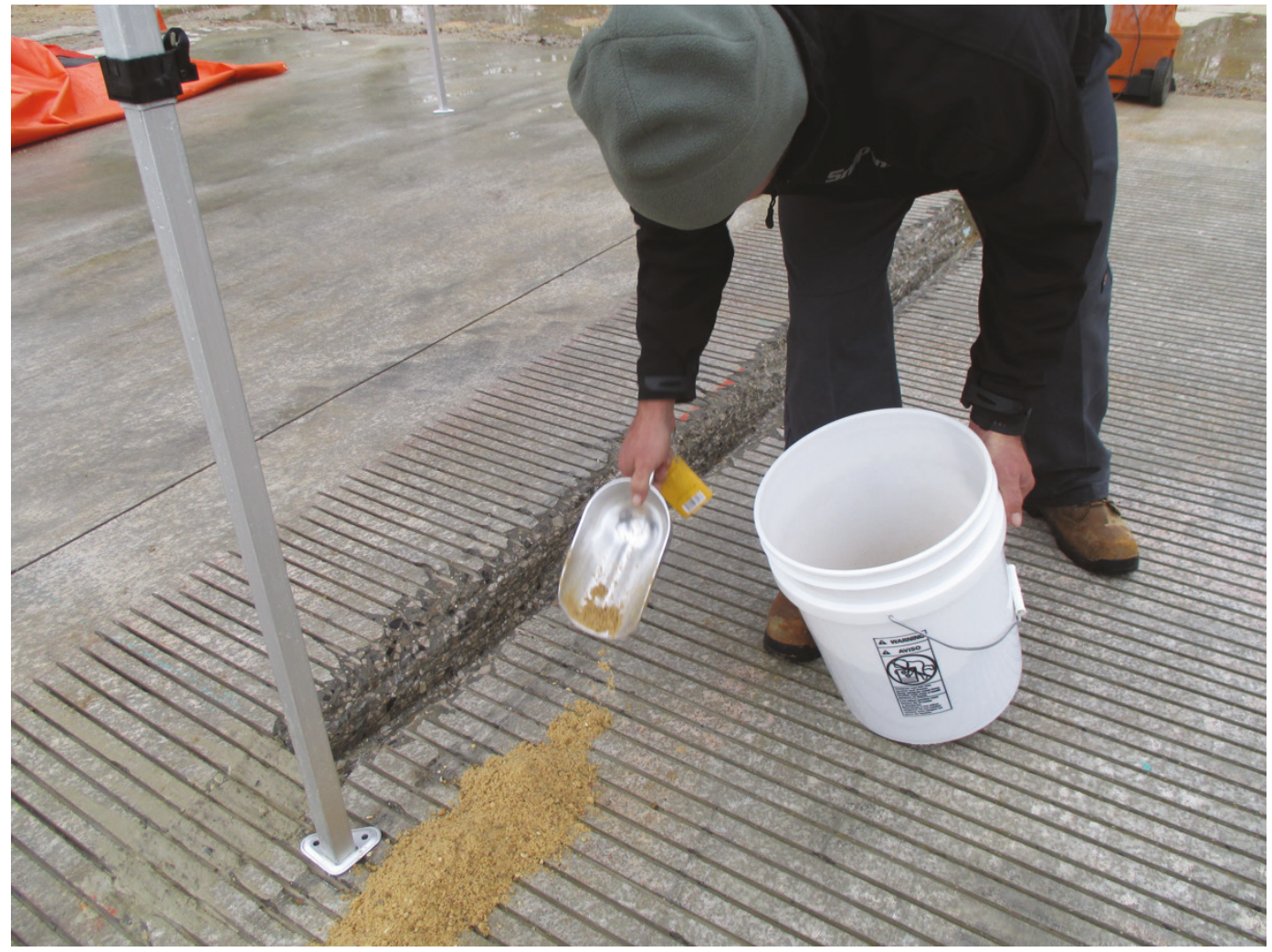


Figure 45. Boot compaction of sand berm.

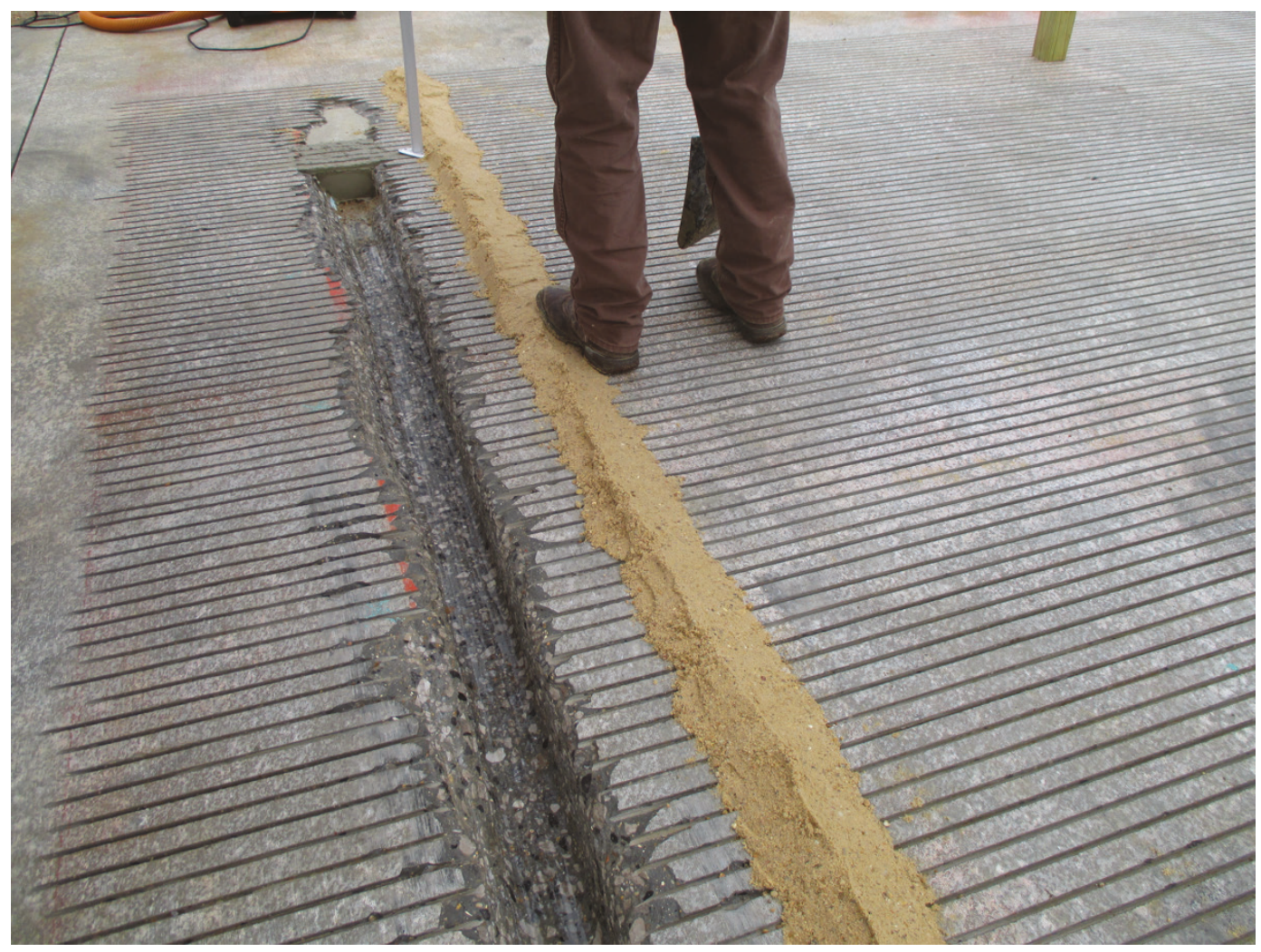

Figure 46. Overall view of sand berm.

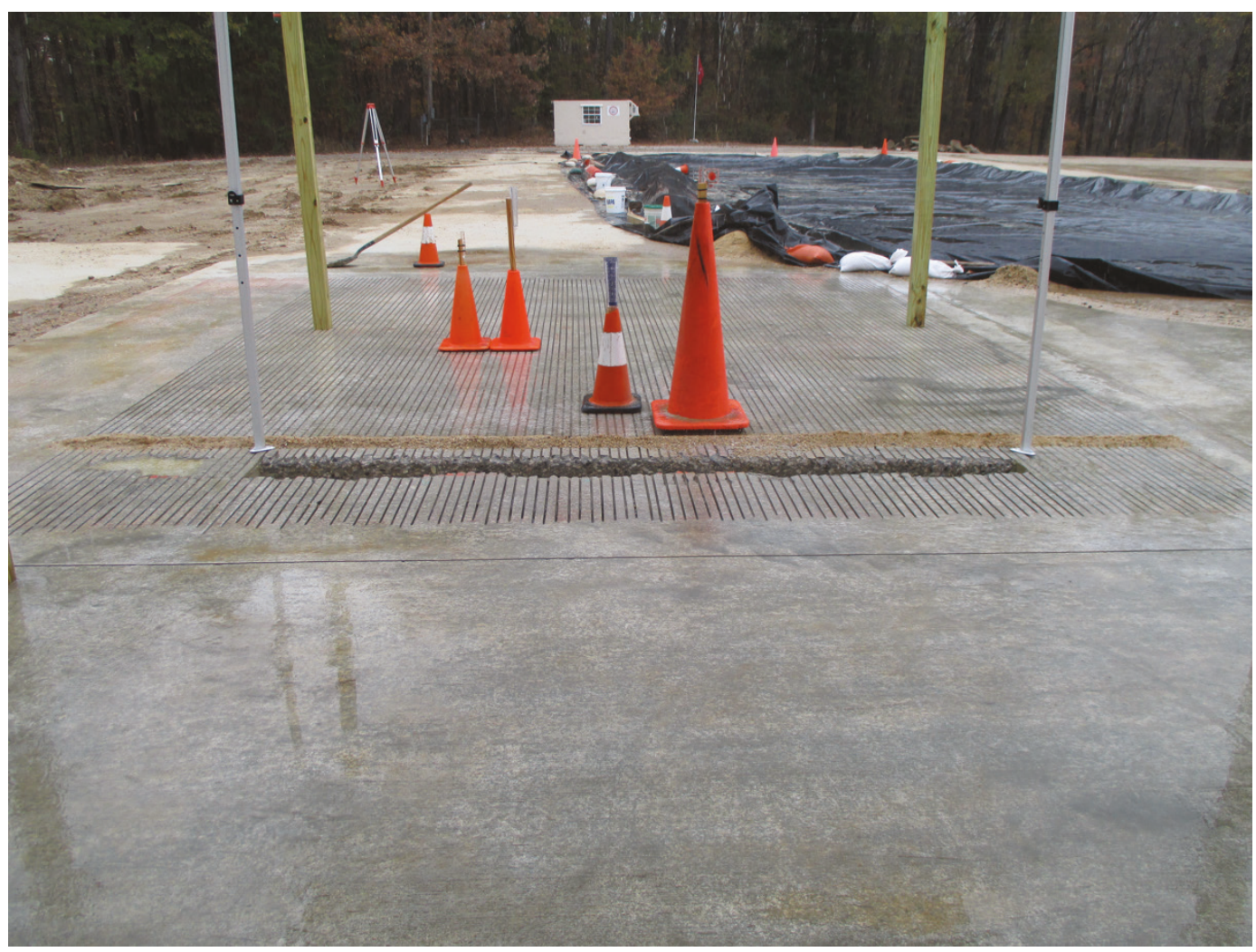


Figure 47. Effect of water runoff from the pop-up tent on the sand barrier.

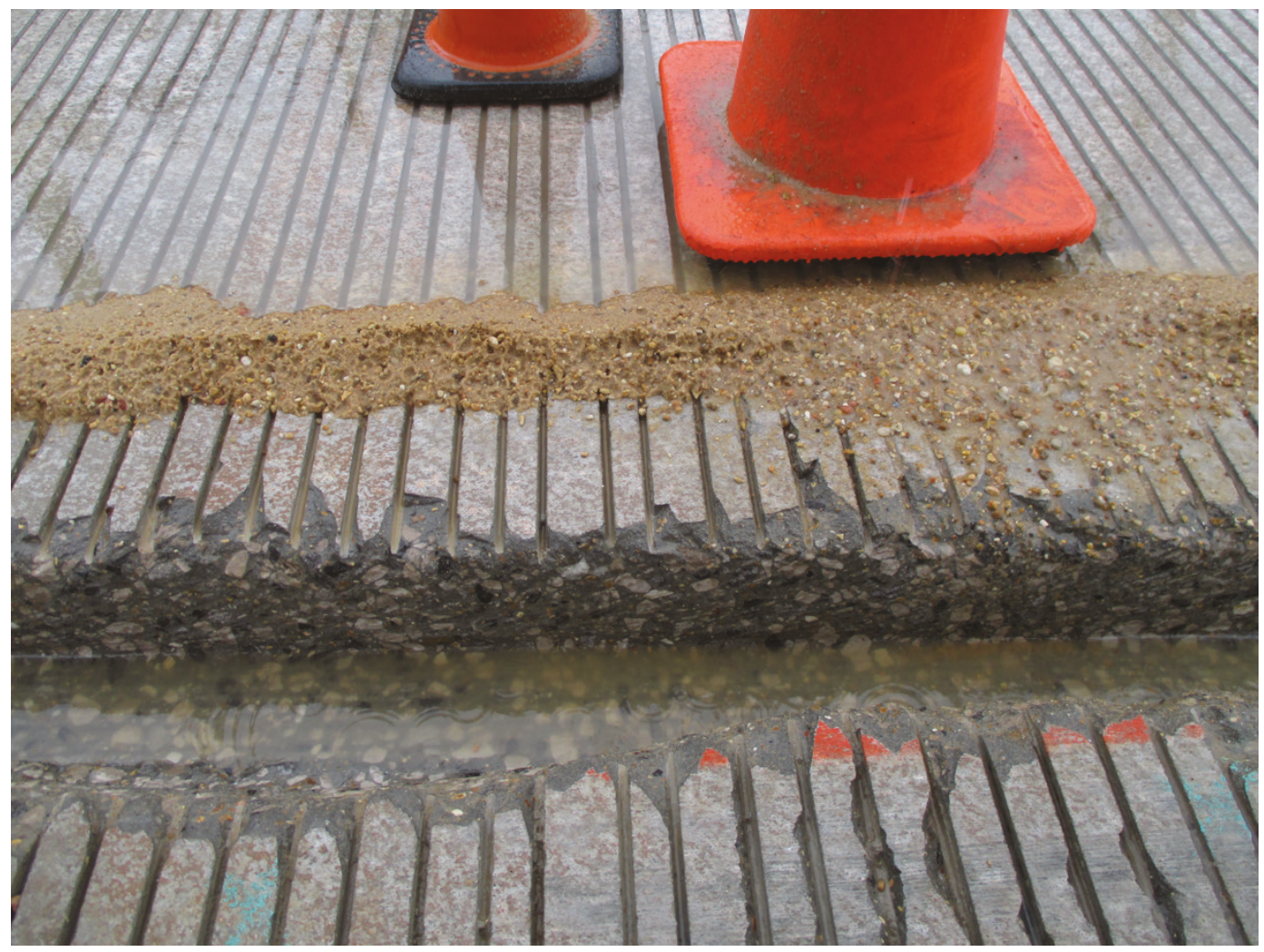

Figure 48. Measuring the depth of collected water in the basin.

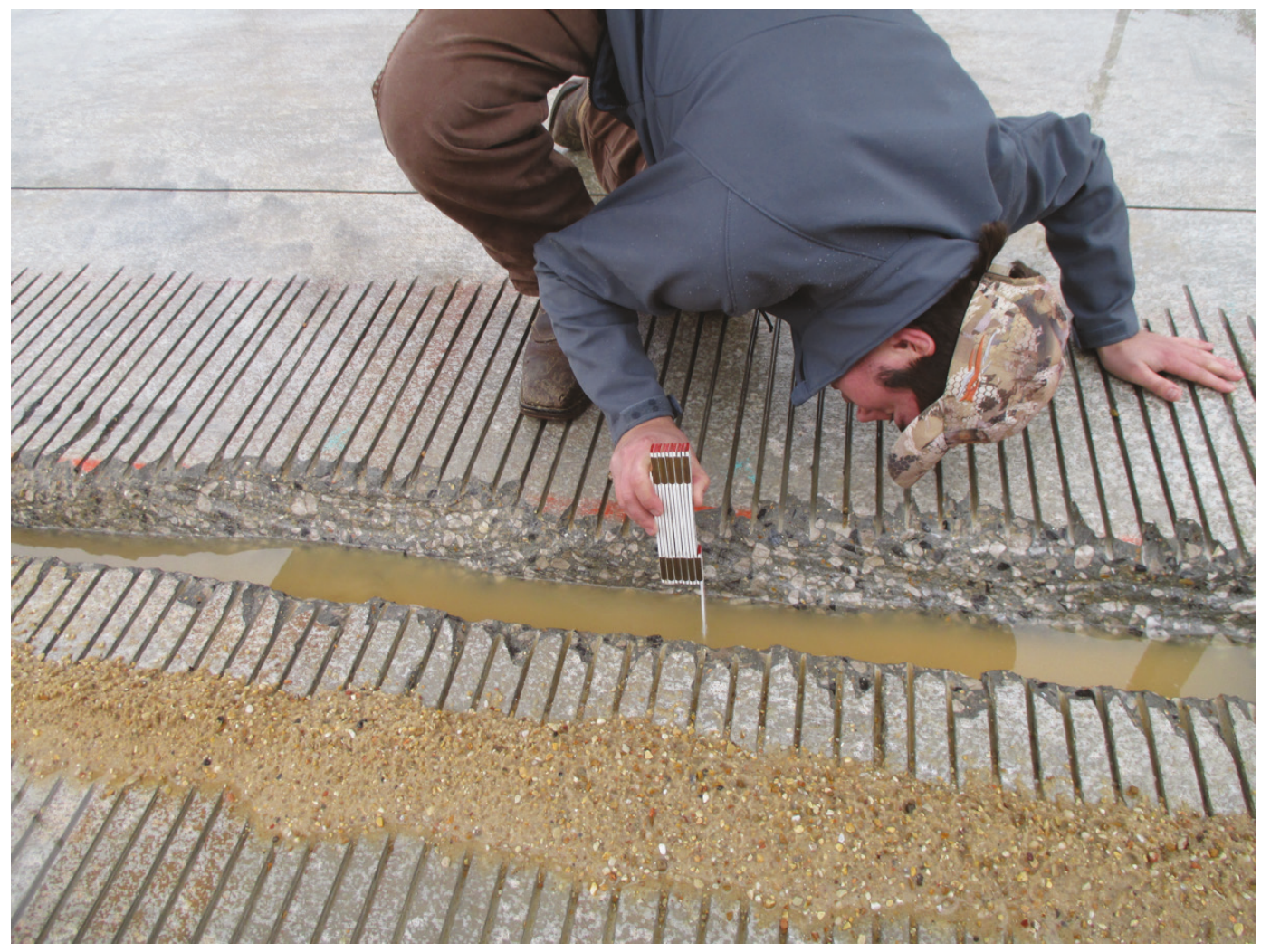




\subsubsection{Control}

For the control, the rain system was operated for 15 min with no water barriers in place. The edge of the pop-up tent was positioned over the basin, however. This set-up gave researchers an idea of how much rainwater flowed through the pavement grooves and ran off the top of the tent. Figure 49 shows the rainwater running off the edge of the tent.

Figure 49. Tent water runoff from simulated rain.

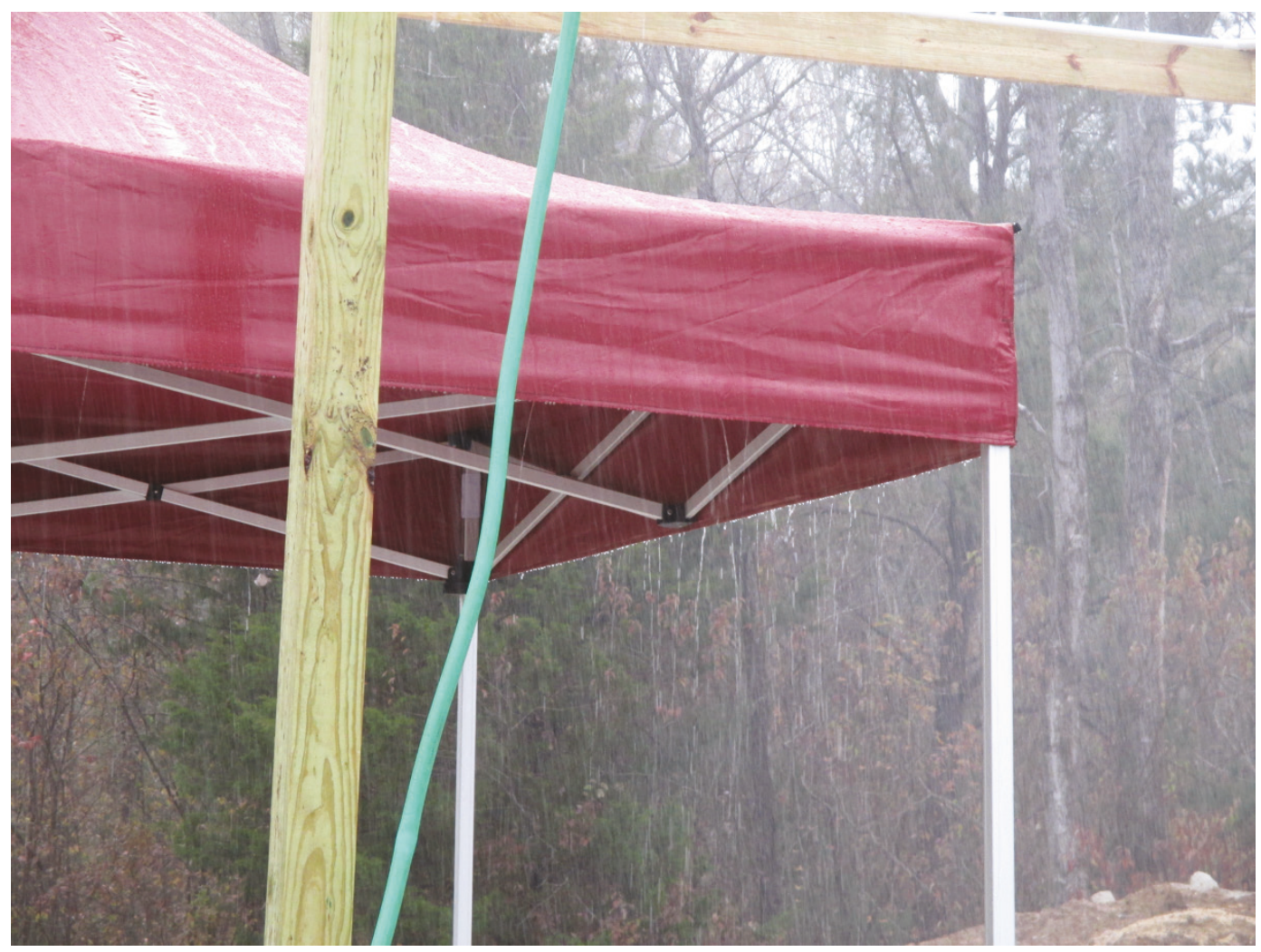

Figure 50 shows the catch basin filling up with water during the test. After $9 \mathrm{~min}$, the basin was full of water ( $2 \mathrm{ft} 3)$. The rain system continued for another $6 \mathrm{~min}$ and averaged $0.23 \mathrm{in}$. of rain, measured with the rain gauges after the 15 -min test. 
Figure 50. Basin filling with rainwater during the control evaluation.

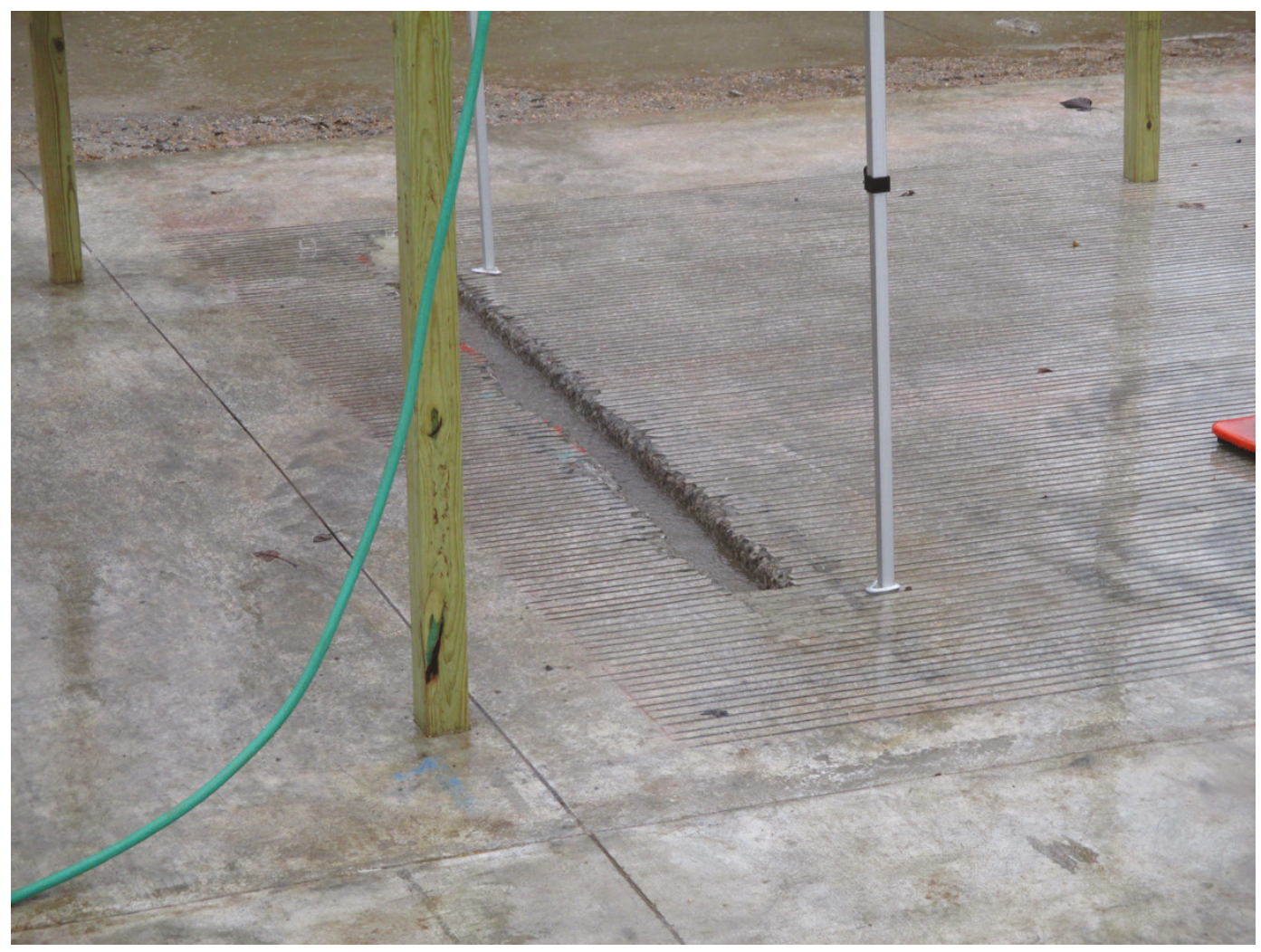

\subsection{Smooth pavement}

The tests conducted on the smooth pavement took place during January 2017. The air temperatures during the evaluation ranged from 37 to $49^{\circ} \mathrm{F}$ with wind blowing out of the west at 3 to $8 \mathrm{mph}$. The humidity averaged $50 \%$.

As with the grooved pavement testing, the sprinkler head mounted on the middle of the top of the rain system was turned off due to it causing excessive rainfall. One rain gauge was mounted on the rain system, and four rain gauges were placed under the rain system inside traffic cones. For each test, the rain system was operated for $15 \mathrm{~min}$; the flow meter gauge was set to $4.5 \mathrm{gal} / \mathrm{min}$, which produced a steady simulated rainfall of approximately $1 \mathrm{in}$./hr. Specific details regarding the rain gauge readings are presented with each test in the following sections.

The water catch basin cut into the smooth pavement was $9.5 \mathrm{ft}$ long, $3.6 \mathrm{in}$. wide, and $8 \mathrm{in}$. deep ( $\left.2 \mathrm{ft}^{3}\right)$. The water depth after each test was measured at the same three quarter points along the length of the basin, and the volume of water collected in the basin was calculated. After each test, all of 
the rainwater was vacuumed out of the basin and the water pooled on top of the pop-up tent was removed. Figure 51 shows the test setup for evaluating water barriers on smooth pavement.

Figure 51. Test setup for smooth pavement.

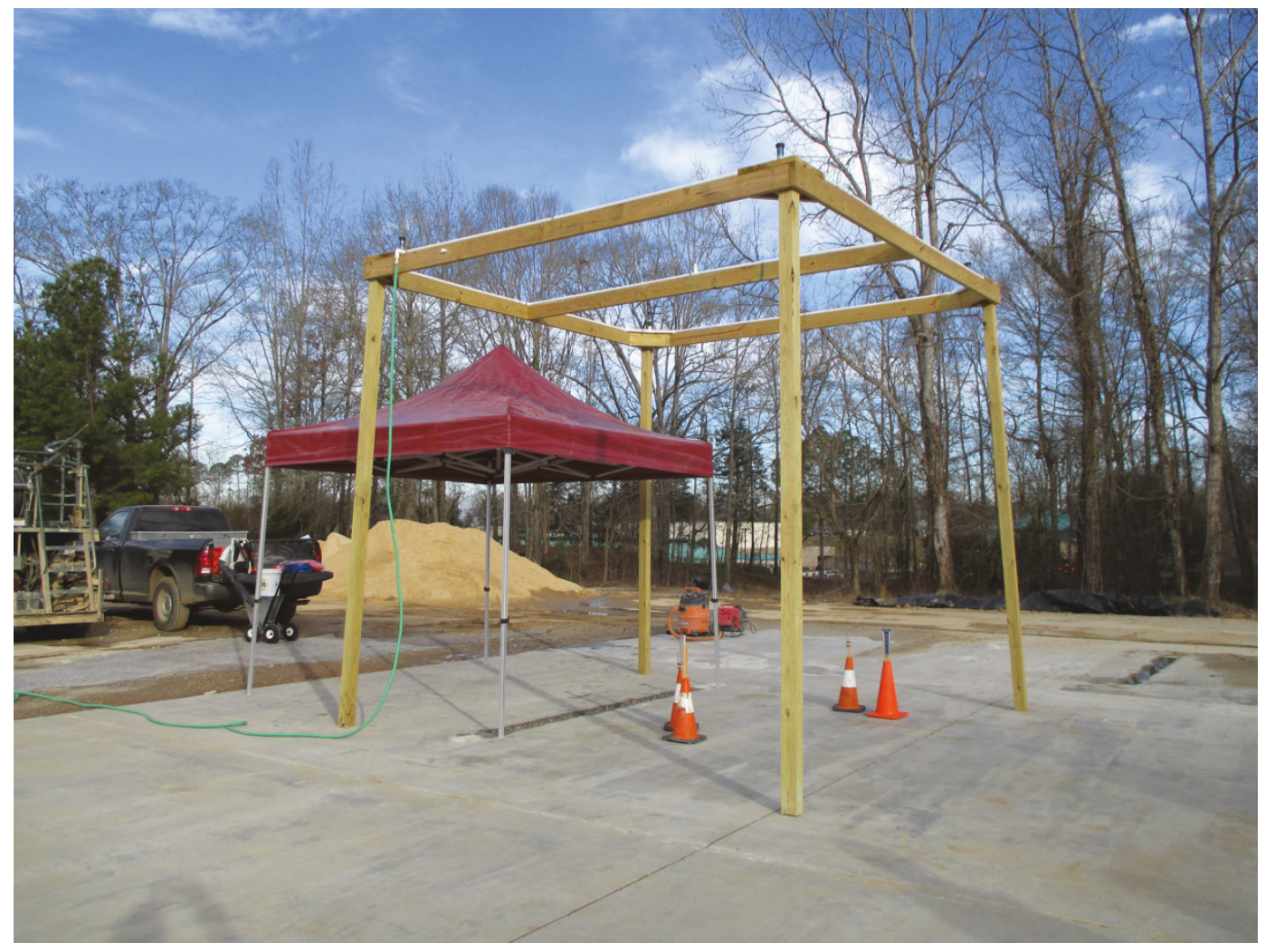

\subsubsection{Quick Dam Expanding Barrier - unsaturated}

A Quick Dam Expanding Barrier was positioned on the smooth concrete on the high side of the basin's edge. The unsaturated Quick Dam was effective at trapping the tent water runoff and somewhat effective for prohibiting the rainwater from entering the basin. After 0.19 in. of the 15 min of simulated rain, the basin collected $0.49 \mathrm{ft}^{3}$ of the precipitation. Figure 52 shows the Quick Dam during testing on the smooth pavement. 
Figure 52. Quick Dam on smooth pavement.

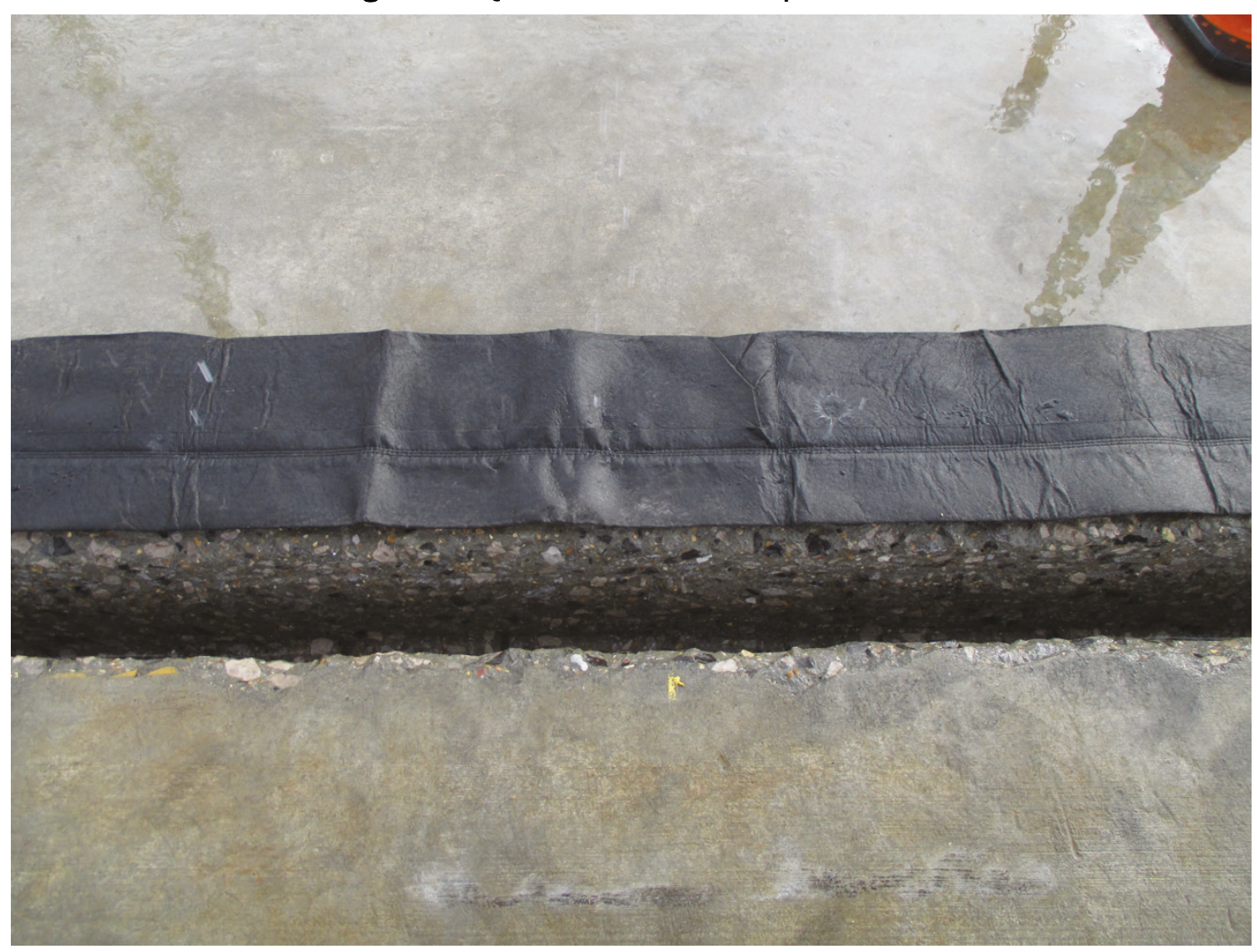

\subsubsection{Quick Dam Expanding Barrier - saturated}

A Quick Dam Expanding Barrier was completely submerged in water so that it fully activated before the 15-min evaluation. The small wedge of the Quick Dam was positioned along the edge of the basin, as shown in Figure 53. After 0.20 in. of simulated rainfall, the basin collected $0.42 \mathrm{ft}^{3}$ of precipitation, which was similar to the performance of the unsaturated Quick Dam.

\subsubsection{Containment dike}

The containment dike was very effective for prohibiting water from flowing into the catch basin on the smooth pavements. The containment dike was able to conform to the smooth pavement. Figure 54 shows the rainwater pooling along the containment dike. The volume of water collected in the basin after the 15 min of simulated rainfall was $0.28 \mathrm{ft} 3$. The majority of the water in the basin was from runoff water on the tent. Figure 55 shows the runoff water trickling from the edge of the tent cover. The total precipitation during this $15-\mathrm{min}$ evaluation was $0.23 \mathrm{in}$. 
Figure 53. Saturated Quick Dam on smooth pavement.

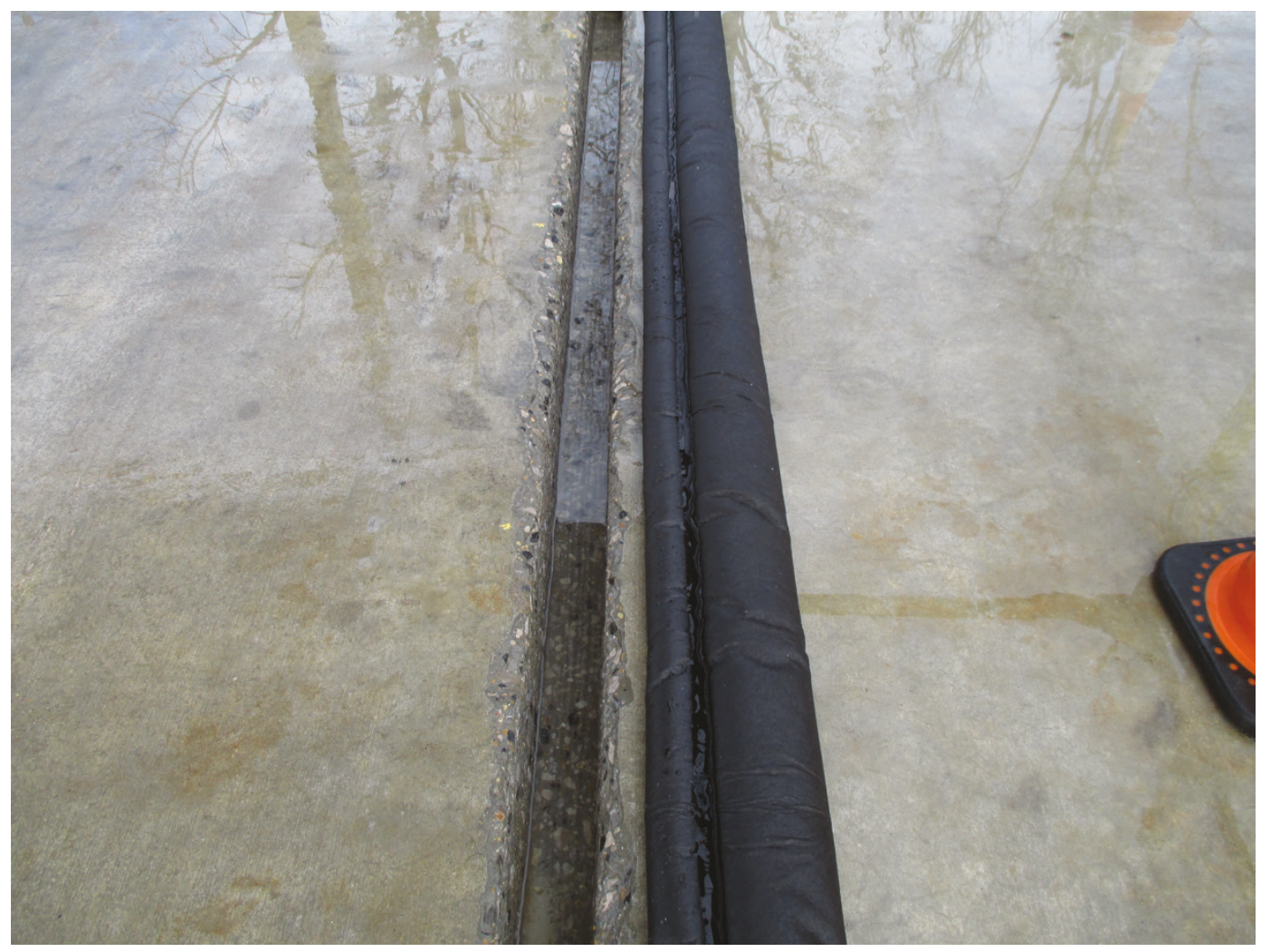

Figure 54. Water pooling along the containment dike.

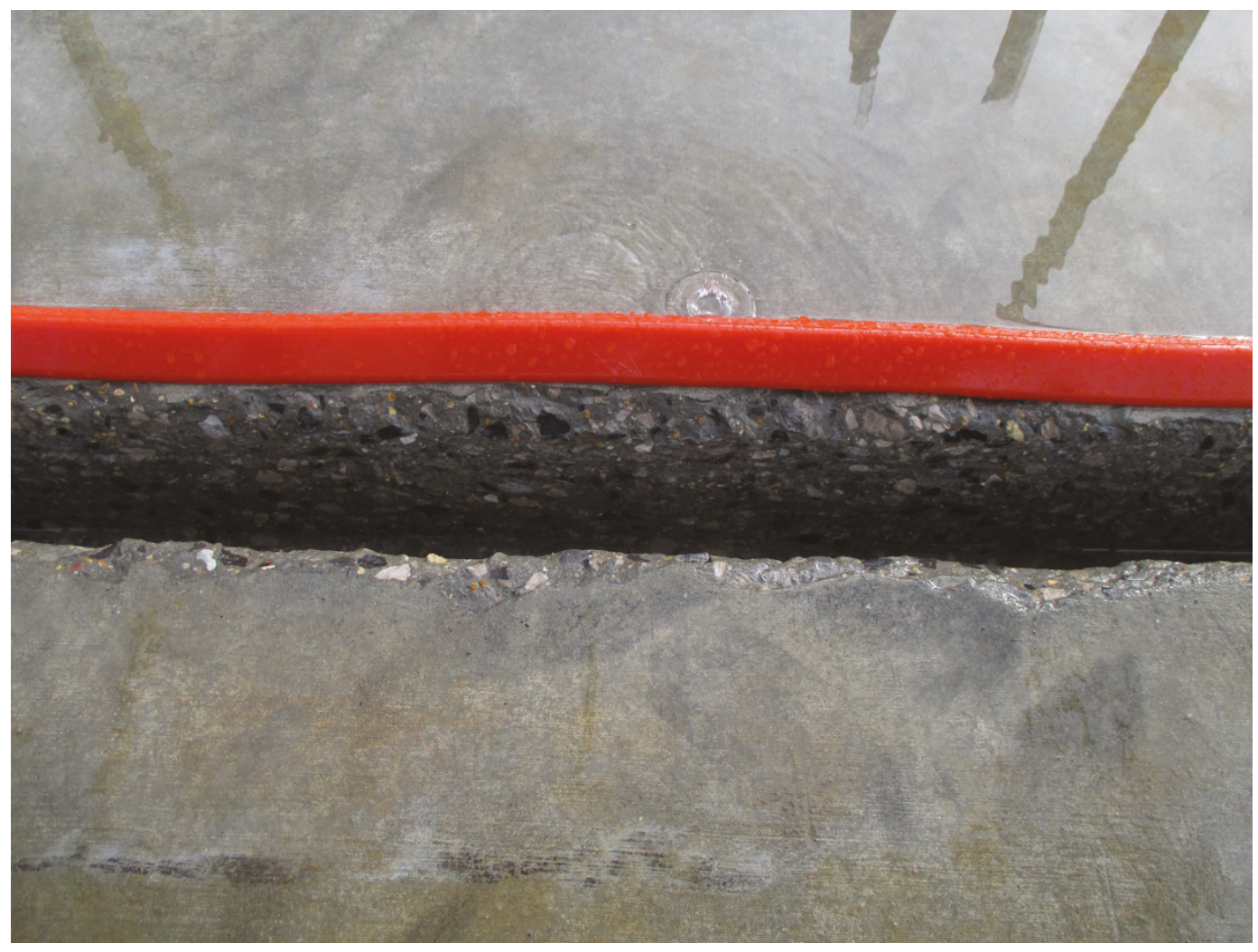


Figure 55. Tent water runoff.

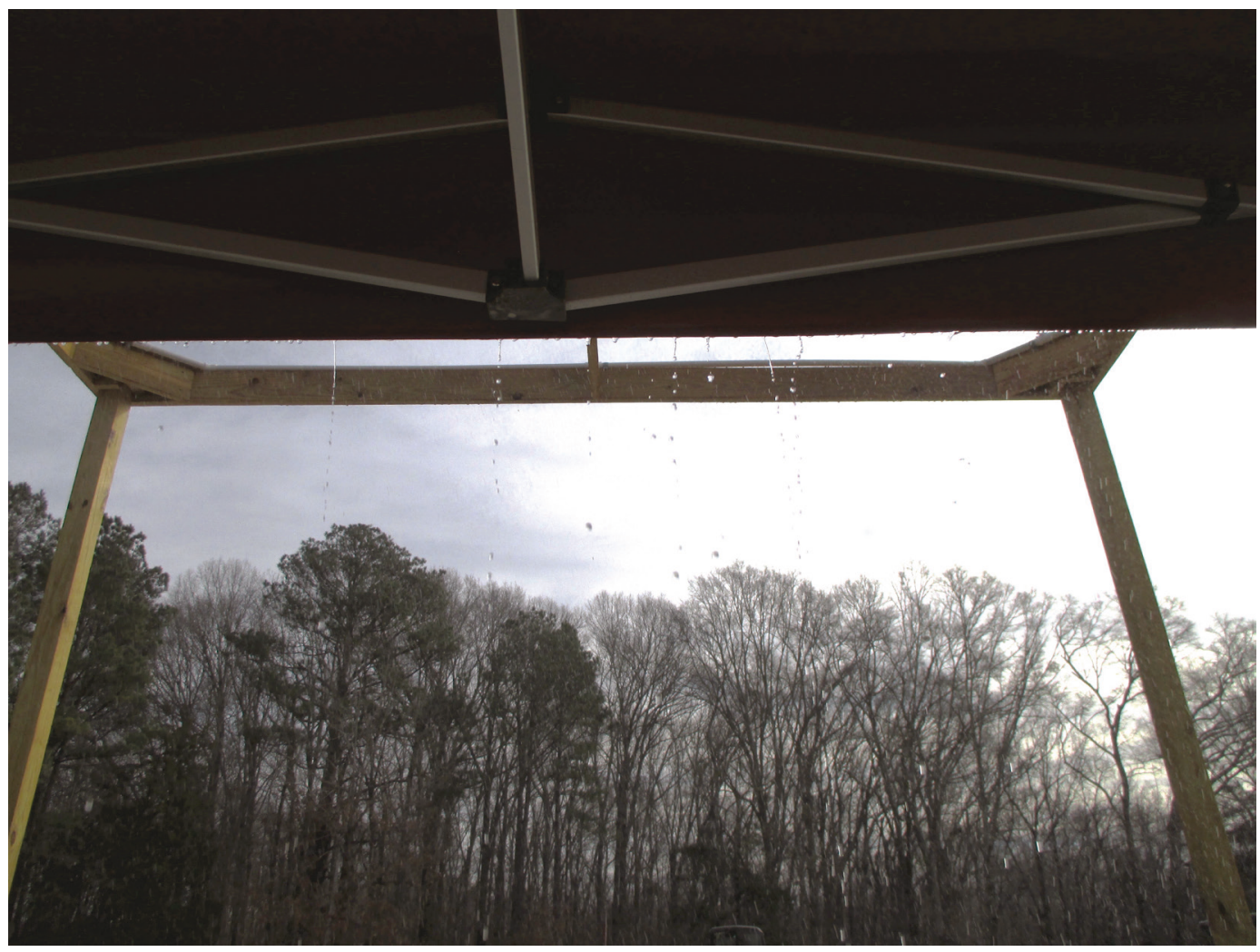

\subsubsection{Fire hose}

The 30-ft-long fire hose segment, partially filled with water, was positioned around the catch basin, as shown in Figure 56. The basin was about $3 / 4$ full after the 15 -min accumulated rainfall of 0.17 in. A large amount of the $1.3-\mathrm{ft}^{3}$ of precipitation inside the basin was a result of tent water runoff. The rainwater would fall from the edge of the tent cover, bounce off the rubber hose, and land in the basin. Figure 57 shows the fire hose during the evaluation.

\subsubsection{Tarp}

A polyvinyl tarp was placed $4.5 \mathrm{ft}$ from the edge of the water collection basin, just as it was positioned on the grooved pavements (Figure 58). As expected, the tarp prohibited the tent water runoff from falling into the basin. The tarp was also effective at preventing much of the surface runoff from flowing into the basin, with just $0.18 \mathrm{ft} 3$ of measured water collected. The total rainfall during the 15 -min evaluation was 0.25 in. 
Figure 56. Fire hose on smooth pavement.

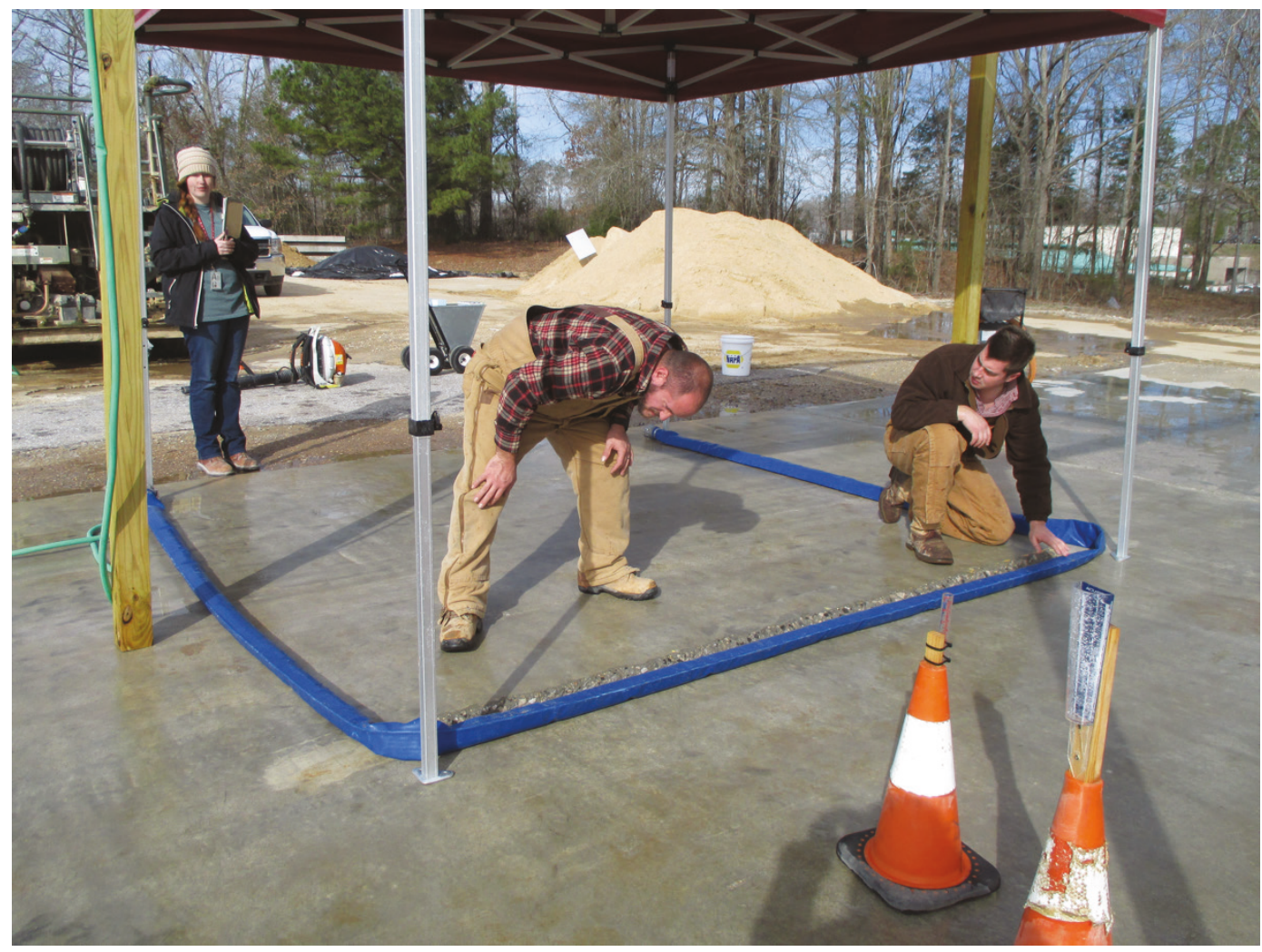

Figure 57. Fire hose water barrier during the smooth pavement test.

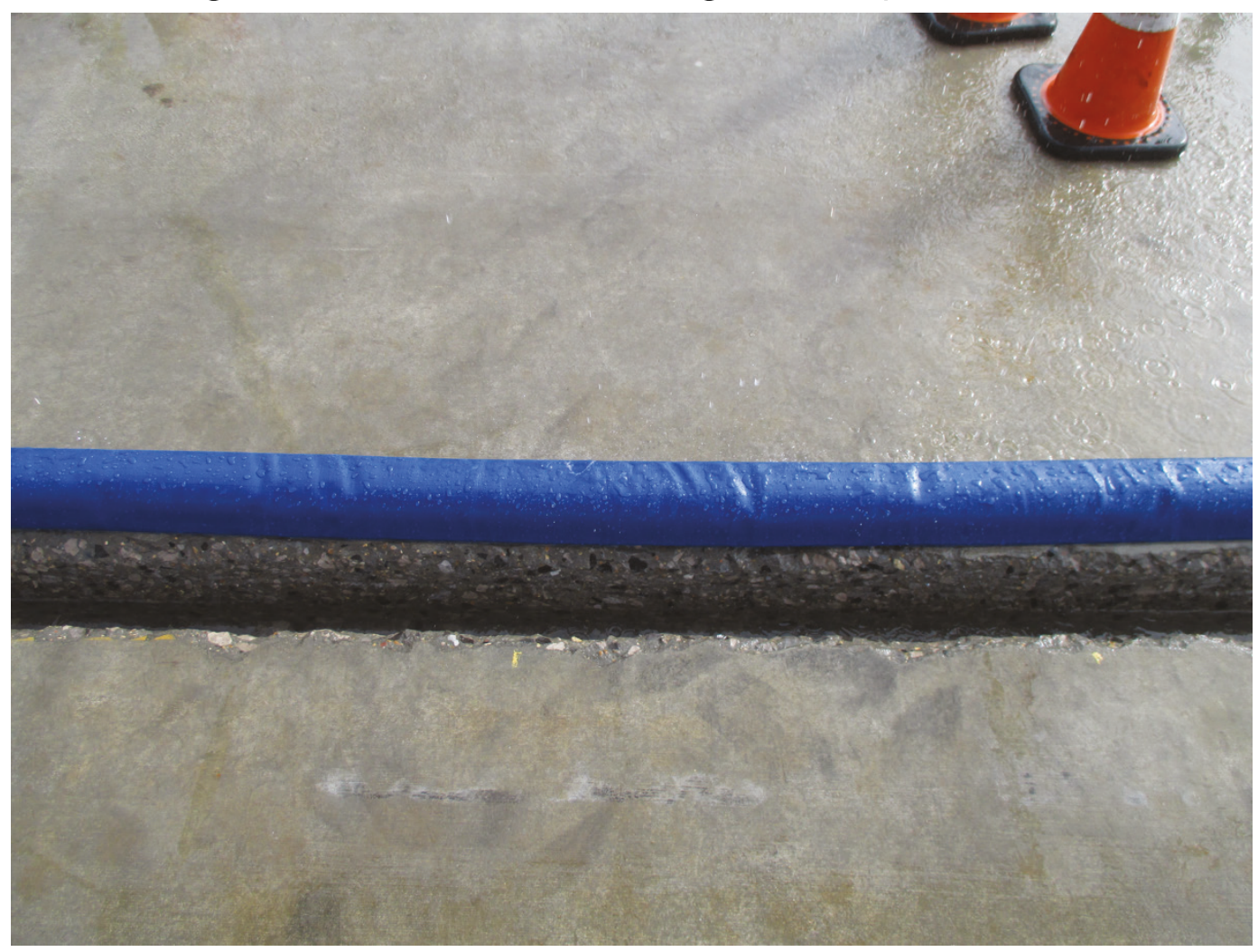


Figure 58. Tarp on smooth pavement.

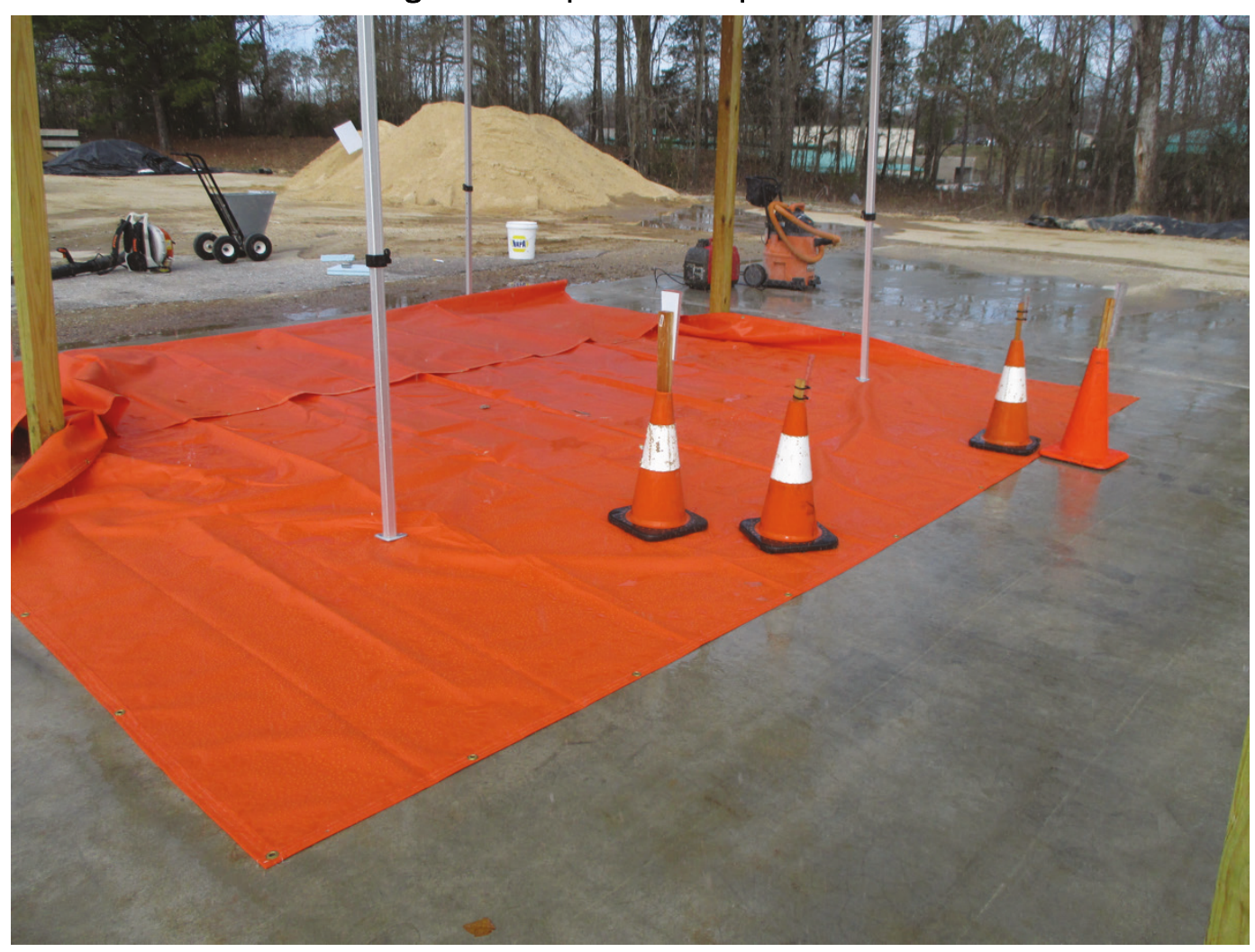

\subsubsection{Tarp, fire hose, and sand}

The combination barrier consisting of the polyvinyl tarp, capped and plugged fire hose partially filled with water, and sand was an effective water barrier on the smooth pavement, just as it was on the grooved pavement. Figure 59 shows a close up of the barrier on the smooth pavement.

It was assumed that the fire hose contributed little to mitigating water entering the basin. The tarp and sand, however, were effective for blocking tent runoff water and surface water, respectively, from entering the basin. The basin collected $0.10 \mathrm{ft} 3$ of water, and the total rainfall measured by the rain gauges averaged $0.24 \mathrm{in}$. during the 15 -min evaluation. 
Figure 59. Tarp, fire hose, and sand barrier on smooth pavement.

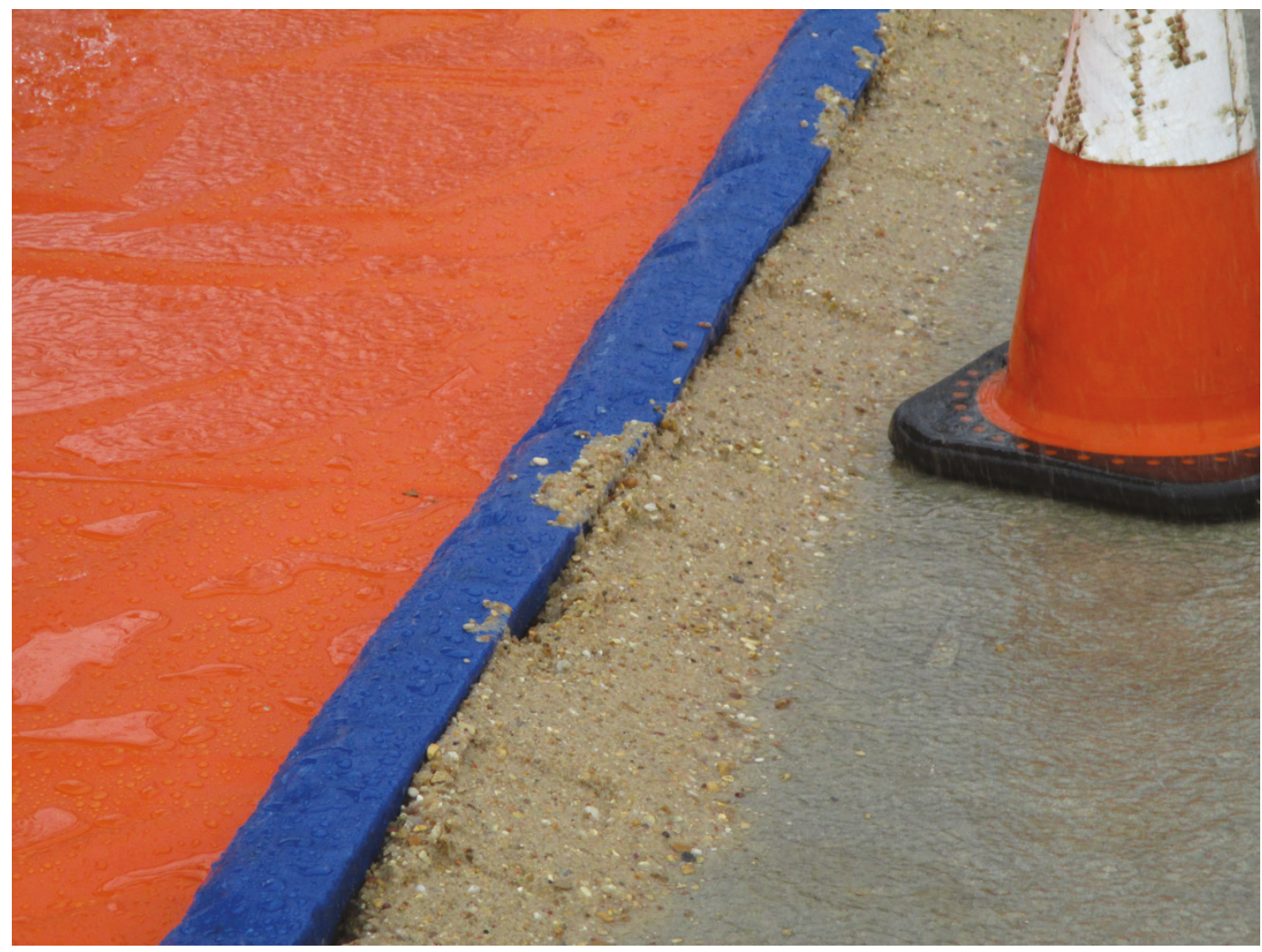

\subsubsection{Sand}

A 6-in.-wide sand berm was placed by pouring sand out of a 5-gal bucket about 2 in. off the high side of the basin. The sand berm formed a mound as it was compacted with a shoe (Figure 60). The mound was approximately 1.5 in. high. With 0.24 in. of total rain, approximately $0.59 \mathrm{ft}^{3}$ of surface groundwater and tent runoff water entered the catch basin during the evaluation. Figure 61 shows damage to one area of the sand berm due to the tent water runoff, which had a minimal effect on the barrier's performance.

\subsubsection{Control}

The rain system was operated for 15 min with just a 10-by-10-ft pop-up tent over the basin cut into the smooth pavement. This gave an indication of how much rainwater could possibly enter an open crater repair during the backfill or capping process with approximately $1 \mathrm{in}$./hr of steady precipitation. After the 15-min test, the basin collected $1.2 \mathrm{ft} 3$ of water, similar to the rainwater collected using the fire hose barrier. 
Figure 60. Compacted sand berm on smooth pavement.

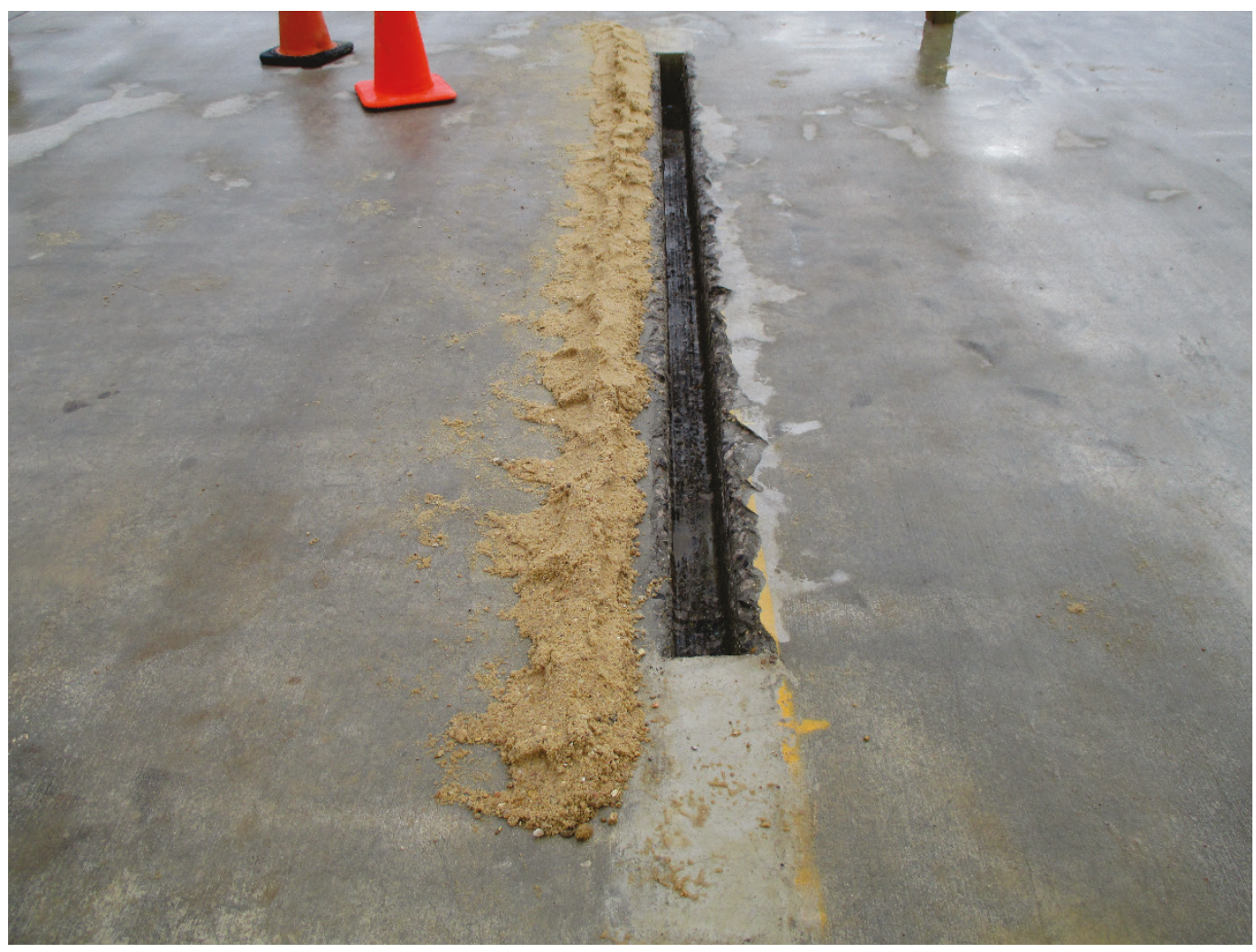

Figure 61. Sand berm damage from tent water runoff.

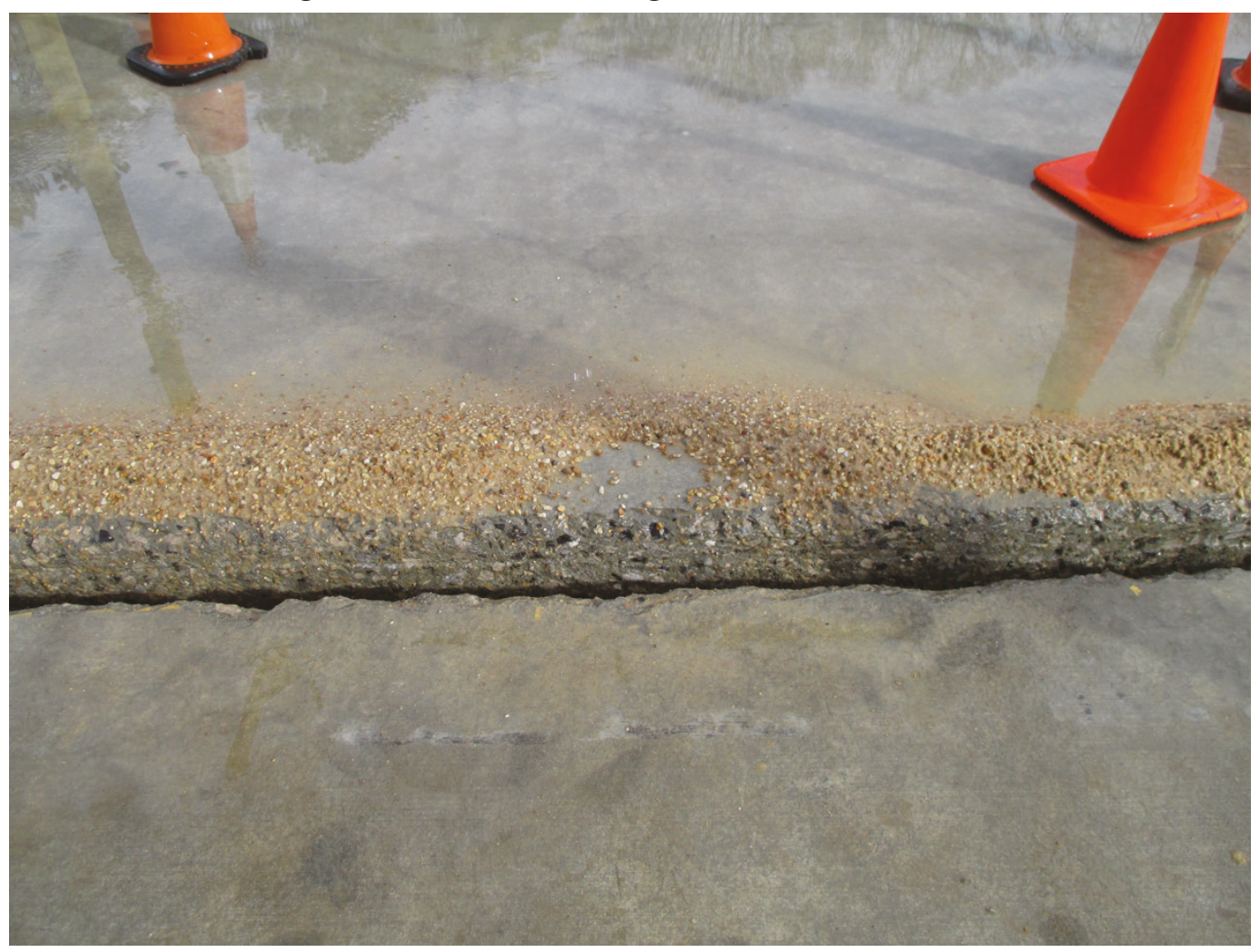




\subsection{Sand dispensing test}

A separate test evaluating the efficiency of placement techniques of a compacted sand berm was conducted on the grooved pavements. The sand berm was placed (1) by using the dry-line marker and (2) by pouring sand out of a bucket and onto the pavement. The sand berms were each approximately $6 \mathrm{in}$. wide and compacted to $0.25 \mathrm{in}$. high when created by using the line marker and $0.5 \mathrm{in}$. high when created by using the bucket. It took 4 min 24 sec to pour sand from a 5-gal bucket into the dry-line marker and spread it out along the 9.5-ft-long basin; this included 43 passes with the machine. Figure 62 shows the small amount of sand that is deposited from the dry-line marker with each pass of the machine. Furthermore, because of the wheels on the dry-line marker, the sand berm could not be placed any closer than approximately $8 \mathrm{in}$. from the edge of the basin.

Figure 62. Using the dry-line marker to deposit sand.

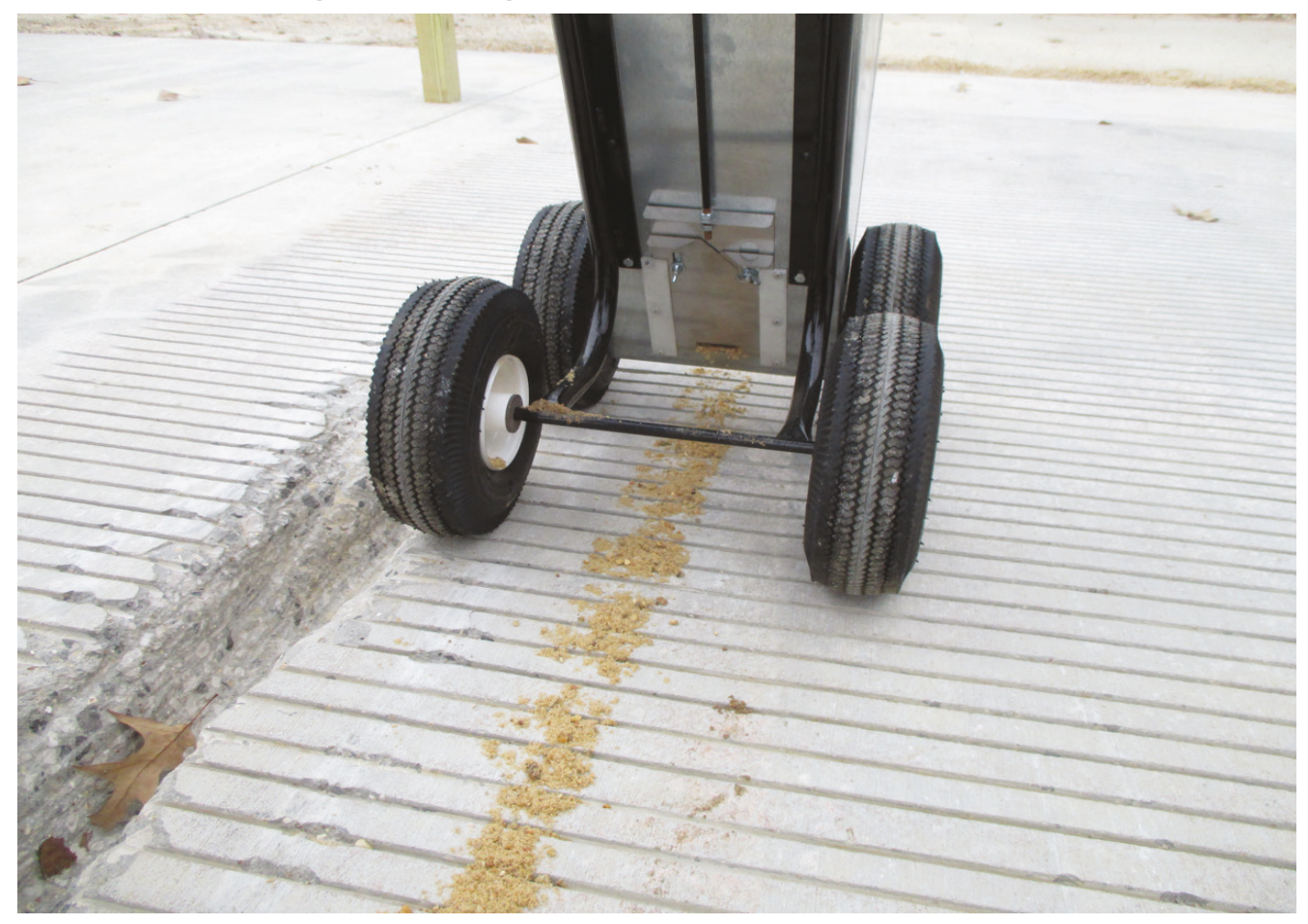

Pouring sand out of the bucket and along the 9.5 -ft-long basin took $32 \mathrm{sec}$ (Figure 63). The bucket placement used approximately twice as much sand as the dry line marker; however, it was a much more efficient method of placement, with respect to time. Figure 64 shows a side-by-side comparison of the sand berm placement techniques. The berm placed by using the 5-gal bucket pour is on the left, and the berm placed by using the dry-line marker is on the right. It is recommended to dispense sand for creating sand berms directly from a 5 -gal bucket. 


$$
\frac{9}{41}
$$




\subsection{Summary of results}

Table 2 and Table 3 present the summary of the test conditions and the results of the various water barriers tested on the grooved and smooth pavements, respectively. All eight tests for each pavement type were conducted with the edge of the 10 -ft-by-10-ft pop-up tent over the edge of the basins cut into the pavements.

The water runoff from the top of the tent on the high ends of the pavement, typically occurring 2 min after the start of the rain system, would sometimes disturb the barriers (e.g., sand) or bounce off the barrier (e.g., fire hose) and into the basin. However, the water runoff from the top of the tent was relatively minimal. The water passing under some of the barriers through the pavement grooves was much more detrimental to the open basin, as evidenced when comparing the control tests from the grooved and smooth pavements. The basin filled with $2 \mathrm{ft} 3$ of rainwater in 9 min with the control test on the grooved pavement, while the basin held $1.2 \mathrm{ft}^{3}$ of rainwater in $15 \mathrm{~min}$ with the control test on the smooth pavement. With essentially the same slope, the water seemed to pool on top of the smooth pavement.

The 2-ft3 basin cut into the grooved pavement filled up within 10 to 13 min when the Quick Dam, containment dike, tarp, and fire hose barriers were used. The water depth was not quite as high when the tarp, placed 4.5 from the edge of the cut, was tested; this was due to tent water runoff not entering the basin because the pavement was covered with the tarp. These barriers still left the pavement grooving exposed, so water was able to run freely into the basin from the grooves. The Quick Dam, containment dike, tarp, and fire hose on the grooved pavement were ineffective and almost as bad as not having a barrier in place, which is evident when the basin filled up after 9 min with no water barrier (control test). Also, the saturated Quick Dam was just as ineffective as the unsaturated Quick Dam. The Quick Dam, fire hose partially filled with water, containment dike, and tarp are not recommended for use as water barriers for crater repairs on grooved pavements during wet weather conditions. 
Table 2. Grooved pavement test summary and results after $15 \mathrm{~min}$ of simulated rain.

\begin{tabular}{|c|c|c|c|c|c|c|c|c|c|c|c|c|c|c|}
\hline \multirow{2}{*}{$\begin{array}{l}\text { Test } \\
\text { No. }\end{array}$} & \multirow{2}{*}{ Barrier } & \multirow{2}{*}{$\begin{array}{c}\text { Air } \\
\text { Temp } \\
\left({ }^{\circ} \mathrm{F}\right) \\
\end{array}$} & \multirow{2}{*}{$\begin{array}{l}\text { Wind } \\
\text { (mph) }\end{array}$} & \multirow{2}{*}{$\begin{array}{l}\text { Time } \\
\text { Start }\end{array}$} & \multirow{2}{*}{$\begin{array}{l}\text { Time } \\
\text { Finish }\end{array}$} & \multirow{2}{*}{$\begin{array}{c}\text { Time } \\
\text { Basin } \\
\text { Full } \\
\end{array}$} & \multirow{2}{*}{$\begin{array}{c}\text { Collected } \\
\text { Vol. of } \\
\text { Water }\left(\mathrm{ft}^{3}\right)\end{array}$} & \multicolumn{6}{|c|}{ Rain Gauge Readings (in.) } & \multirow{2}{*}{$\begin{array}{l}\text { Rainfal } \\
\text { (in./hr) }\end{array}$} \\
\hline & & & & & & & & 1 & 2 & 3 & 4 & 5 & Avg. & \\
\hline 1 & Quick Dam - Unsaturated & 47 & 8 & 0825 & 0840 & 0838 & $2.0+$ & 0.18 & 0.29 & 0.15 & 0.09 & 0.25 & 0.19 & 0.76 \\
\hline 2 & Quick Dam - Saturated & 47 & 7 & 0854 & 0909 & 0905 & $2.0+$ & 0.10 & 0.10 & 0.20 & 0.09 & 0.35 & 0.17 & 0.67 \\
\hline 3 & Containment Dike & 48 & 6 & 0928 & 0944 & 0938 & $2.0+$ & 0.10 & 0.18 & 0.30 & 0.10 & 0.30 & 0.20 & 0.78 \\
\hline 4 & Fire Hose & 47 & 6 & 1000 & 1015 & 1011 & $2.0+$ & 0.18 & 0.30 & 0.15 & 0.20 & 0.30 & 0.23 & 0.90 \\
\hline 5 & Tarp & 47 & 7 & 1030 & 1045 & 1045 & 2.0 & 0.20 & 0.22 & 0.15 & 0.20 & 0.30 & 0.21 & 0.86 \\
\hline 6 & Tarp with Fire Hose and Sand Berm & 47 & 9 & 1413 & 1428 & ----- & 0.24 & 0.28 & 0.21 & 0.20 & 0.20 & 0.30 & 0.24 & 0.95 \\
\hline 7 & Sand Berm (with Scoop) & 46 & 7 & 1450 & 1505 & ----- & 0.68 & 0.50 & 0.28 & 0.15 & 0.25 & 0.25 & 0.29 & 1.14 \\
\hline 8 & None & 45 & 7 & 1515 & 1530 & 1524 & $2.0+$ & 0.20 & 0.30 & 0.15 & 0.20 & 0.28 & 0.23 & 0.90 \\
\hline
\end{tabular}

Table 3. Smooth pavement test summary and results after $15 \mathrm{~min}$ of simulated rain.

\begin{tabular}{|c|c|c|c|c|c|c|c|c|c|c|c|c|c|c|}
\hline \multirow{2}{*}{$\begin{array}{l}\text { Test } \\
\text { No. }\end{array}$} & \multirow{2}{*}{ Barrier } & \multirow{2}{*}{$\begin{array}{c}\text { Air } \\
\text { Temp } \\
\left({ }^{\circ} \mathrm{F}\right) \\
\end{array}$} & \multirow{2}{*}{$\begin{array}{l}\text { Wind } \\
\text { (mph) }\end{array}$} & \multirow{2}{*}{$\begin{array}{l}\text { Time } \\
\text { Start }\end{array}$} & \multirow{2}{*}{$\begin{array}{l}\text { Time } \\
\text { Finish }\end{array}$} & \multirow{2}{*}{$\begin{array}{c}\text { Time } \\
\text { Basin } \\
\text { Full } \\
\end{array}$} & \multirow{2}{*}{$\begin{array}{c}\text { Collected } \\
\text { Vol. of } \\
\text { Water }\left(\mathrm{ft}^{3}\right)\end{array}$} & \multicolumn{6}{|c|}{ Rain Gauge Readings (in.) } & \multirow{2}{*}{$\begin{array}{l}\text { Rainfal } \\
\text { (in./hr) }\end{array}$} \\
\hline & & & & & & & & 1 & 2 & 3 & 4 & 5 & Avg. & \\
\hline 1 & Quick Dam - Unsaturated & 39 & 3 & 913 & 928 & ----- & 0.49 & 0.20 & 0.30 & 0.30 & 0.10 & 0.05 & 0.19 & 0.76 \\
\hline 2 & Quick Dam - Saturated & 39 & 3 & 939 & 954 & ----- & 0.42 & 0.20 & 0.35 & 0.30 & 0.10 & 0.05 & 0.20 & 0.80 \\
\hline 3 & Containment Dike & 37 & 3 & 846 & 901 & ---- & 0.28 & 0.30 & 0.35 & 0.35 & 0.10 & 0.05 & 0.23 & 0.92 \\
\hline 4 & Fire Hose & 39 & 3 & 1009 & 1024 & ---- & 1.30 & 0.25 & 0.20 & 0.25 & 0.10 & 0.05 & 0.17 & 0.68 \\
\hline 6 & Tarp with Fire Hose and Sand Berm & 49 & 8 & 1350 & 1405 & ---- & 0.10 & 0.25 & 0.30 & 0.30 & 0.25 & 0.10 & 0.24 & 0.96 \\
\hline 7 & Sand Berm (with Scoop) & 48 & 7 & 1426 & 1441 & ----- & 0.59 & 0.20 & 0.20 & 0.40 & 0.30 & 0.10 & 0.24 & 0.96 \\
\hline 8 & None & 49 & 8 & 1302 & 1317 & ----- & 1.20 & 0.30 & 0.35 & 0.20 & 0.20 & 0.10 & 0.23 & 0.92 \\
\hline
\end{tabular}


The combination barrier constisting of the tarp, fire hose partially filled with water, and sand berm were effective in water mitigation through the pavement grooves and into the open basin. The sand berm was placed along the edge of the tarp, which was placed $3 \mathrm{ft}$ past the basin, and into the pavement grooves. This combination was mainly effective because the tarp prevented tent runoff water from entering the basin and the sand blocked the water flowing through the pavement grooves. The fire hose did not seem to be needed.

Test 7 on the grooved pavement was evaluated with just a 6-in.-wide compacted sand berm that was approximately $1.5 \mathrm{in}$. high. The sand berm was not quite as effective as the tarp, fire hose, and sand berm combination; however, the sand berm worked well as a water barrier for the open basin. The cause of the difference in performance between the two barriers was the water runoff from the tent. The tarp was able to keep the tent runoff water from entering the open basin. Without the tarp, the runoff water from the tent landed directly on the sand berm, which was placed along the edge of the basin, hindering the barrier from completely performing its job. Nonetheless, the compacted sand berm was effective as a water barrier when repairing craters in wet weather conditions and is recommended for use over the sand berm, tarp, and fire hose combination. The combination barrier is more logistically challenging and is not as economical as using just sand.

For grooved pavements, it is recommended to use a 6-in.-wide compacted sand berm as a water barrier for repairing craters in wet weather. The sand barrier should be put in place by pouring from a 5 -gal bucket and compacting the sand into the pavement grooves. The compaction can be done with a shoe. When compaction is complete, the sand berm should form a mound at least $0.5 \mathrm{in}$. high above the pavement surface.

Reparing craters in wet weather conditions is not as detrimental with the smooth pavements as it is with the grooved pavements, as shown by the volume of water collected with each barrier (Table 2 and Table 3). The volume of water in the basins was much less with the smooth pavements than with the grooved pavements, even without a barrier in place. All the barriers evaluated on the smooth pavements were effective for mitigating runoff rainwater from entering the basin. The fire hose partially filled with water resulted in the largest volume of water in the basin, even more than not using a barrier at all (control). However, with the fire hose barrier, the 
water was mainly collected from the tent's runoff water bouncing off the fire hose and into the basin. This was also the case for the containment dike.

The saturated and unsaturated Quick Dam Expanding Barriers resulted in essentially the same amount of rainfall collecting in the basin. The tarp alone and the fire hose, tarp, and sand berm combination were the most effective barriers for the smooth pavement. Nonetheless, as with the grooved pavements, using the tarp, fire hose, and sand berm combination barrier is not logistically friendly and is more labor intensive. For repairing craters in smooth pavements during wet weather scenarios, it is recommended to use a tarp or a 6-in.-wide compacted sand berm as a water barrier. 


\section{Conclusions and Recommendations}

The ERDC performed full-scale field evaluations of runoff control measures to be used when repairing craters in wet weather on grooved and smooth pavements. The key technology to identify was the most effective barrier(s) or a barrier combination for protecting an open crater repair area from water runoff during wet weather.

Along with a pop-up tent over the simulated repair area at all times, seven different types of water barriers - a saturated Quick Dam Expanding Barrier; an unsaturated Quick Dam Expanding Barrier; a containment dike; a fire hose; a tarp; sand; and a tarp, sand, and fire hose combination - were evaluated in increments of $15 \mathrm{~min}$ with approximately $1 \mathrm{in} . / \mathrm{hr}$ of steady simulated rainfall. A control using just the pop-up tent without barriers for surface runoff was assessed for each of the two pavement types. The following sections present the findings from the evaluation.

\subsection{Conclusions}

- A 10-ft-by-10-ft heavy duty pop-up tent is a necessity for protecting the open crater repair area from direct rainfall. The tent also serves as a cover for the auger of the simplified volumetric mixer during backfill and/or capping. The tent needs to be heavy to prevent it from blowing away with high winds, unless the legs are anchored. A 12-ft-by-12-ft tent would likely be a better size, considering the water runoff from the 10-ft-by-10-ft tent falls into the open crater repairs.

- The most effective water barrier for smooth and grooved pavements was the tarp, fire hose, and sand berm combination. However, fabricating this barrier was time consuming and labor intensive. Also, the fire hose did not appear to provide additional benefit.

- The Quick Dams, containment dikes, sand berms, and tarp work well for smooth pavements.

- The fire hose partially filled with water was ineffective for grooved and smooth pavements. There are too many areas where the hose does not make contact with the pavement surface to keep the water from entering the open crater repair area.

- The dry-line marker filled with sand was inefficient. Using the dry-line marker to place a sand berm was time consuming and not necessary. A comparison showed that placing sand by pouring out of a 5 -gal bucket was more efficient than placing sand using the dry-line marker. 
- A 6-in.-wide and 0.5-in.-high compacted sand berm works well as a protective water barrier for both grooved and smooth pavements. Approximately $10 \mathrm{ft}^{3}$ of sand would be needed to form 10-ft-long sand berms on the high side of 18 craters.

\subsection{Recommendations}

- It is recommended to use a minimum size of $10 \mathrm{ft}$ by $10 \mathrm{ft}$ for a pop-up tent to place over open small crater repair areas when repairing during wet weather.

- It is recommended to use sand as the water mitigation technology for repairing craters on grooved and smooth pavements. The sand should be poured by hand and should be approximately 6 in. wide and compacted; boot compaction is sufficient. For placement, the sand can be gathered locally, if available, and placed in the empty 5-gal buckets that are included in the Inclement Weather Crater Repair Tool Kit. Alternatively, a minimum of $10 \mathrm{ft}^{3}$ of sand should be included in the kit if not locally available.

- A coated polyvinyl tarp is also a good option for smooth pavements. The tarp is already included in the Inclement Weather Crater Repair Tool Kit because it is needed for compaction of asphalt caps.

- It is recommended that the containment dikes, dry-line marker, hand scoop, capped and plugged fire hoses, and sieves be removed from the Inclement Weather Crater Repair Tool Kit. 


\section{References}

American Society for Testing and Materials (ASTM). 2011. Standard specification for liquid membrane-forming compounds for curing concrete. Designation C309-11. West Conshohocken, PA: ASTM International. . 2016a. Standard test method for compressive strength of cylindrical concrete specimens. Designation C39/C39M-16. West Conshohocken, PA: ASTM International.

.2016b. Standard test method for flexural strength of concrete (using simple beam with third-point loading). Designation C78/C78M-16. West Conshohocken, PA: ASTM International.

Bell, H. P., L. Edwards, W. D. Carruth, J. S. Tingle, and J. R. Griffin. 2013. Wet weather crater repair testing at Silver Flag Exercise Site, Tyndall Air Force Base, Florida. ERDC/GSL TR-13-42. Vicksburg, MS: U.S. Army Engineer Research and Development Center.

Bell, H. P. and J. S. Tingle. 2017. Inclement weather crater repair tool kit. ERDC/GSL TR-17-26. Vicksburg, MS: U.S. Army Engineer Research and Development Center.

Pullen, A., C. Jackson, and B. Cotter. 2014. 2013 wet weather HMA crater repair technology demonstration. AFCEC-CX-TY-TR-2014-0026. Panama City, FL: Applied Research Associates.

Unified Facilities Criteria (UFC). 2001. Pavement design for airfields. UFC 3-260-02. Construction Criteria Base. Washington, D.C.: National Institute of Building Sciences.

Unified Facilities Guide Specifications (UFGS). 2008. Grooving for airfield pavements. UFGS 3201 26.71. Washington, D.C.: United States Department of Defense. 


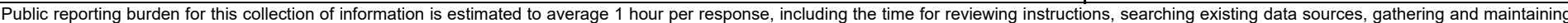

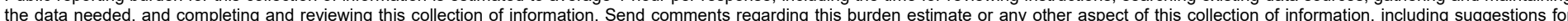

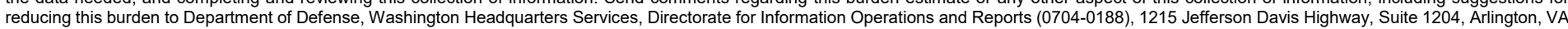

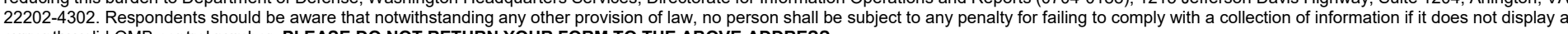
currently valid OMB control number. PLEASE DO NOT RETURN YOUR FORM TO THE ABOVE ADDRESS.
1. REPORT DATE (DD-MM-YYYY) April 2018
Final report

\section{TITLE AND SUBTITLE}

Wet Weather Crater Repair Technologies for Grooved and Smooth Pavements

\section{AUTHOR(S)}

Haley P. Bell, Cecilia L. Dean, Craig A. Rutland

\section{PERFORMING ORGANIZATION NAME(S) AND ADDRESS(ES)}

U.S. Army Engineer Research and Development Center

Geotechnical and Structures Laboratory

3909 Halls Ferry Road

Vicksburg, MS 39180-6199

\section{SPONSORING / MONITORING AGENCY NAME(S) AND ADDRESS(ES)}

Headquarters, Air Force Civil Engineer Center

Tyndall Air Force Base, FL 32403-5319

\section{DATES COVERED (From - To)}

5a. CONTRACT NUMBER

5b. GRANT NUMBER

5c. PROGRAM ELEMENT NUMBER

5d. PROJECT NUMBER

457442

5e. TASK NUMBER

5f. WORK UNIT NUMBER

8. PERFORMING ORGANIZATION REPORT NUMBER

ERDC/GSL TR-18-6

10. SPONSOR/MONITOR'S ACRONYM(S)

AFCEC

11. SPONSOR/MONITOR'S REPORT NUMBER(S)

\section{DISTRIBUTION / AVAILABILITY STATEMENT}

Approved for public release; distribution is unlimited.

\section{SUPPLEMENTARY NOTES}

\section{ABSTRACT}

A research study was conducted at the U.S. Army Engineer Research and Development Center (ERDC) in Vicksburg, MS, to evaluate methods for preventing rainfall runoff from entering open bomb craters during wet weather repairs. The study evaluated the use of seven commercial off-the-shelf barriers on both smooth and grooved concrete pavements. Water runoff, particularly in grooved concrete pavements, is one of the greatest challenges for repairing craters in wet weather. Also included in the evaluation was a heavy duty popup tent placed over the open repair area. This report presents the technical evaluation of the various water barriers and the pop-up tent using simulated rainfall of approximately $1 \mathrm{in./hr}$. Results indicate that, along with a pop-up tent, a 6-in.-wide berm of compacted sand is the most effective barrier for grooved and smooth pavements. A polyvinyl tarp is also effective for smooth pavements. A sand berm, polyvinyl tarp, and a pop-up tent are recommended for use as supplemental items by crater repair teams during times of wet weather.

\begin{tabular}{|c|c|c|c|c|c|}
\hline \multicolumn{2}{|l|}{$\begin{array}{l}\text { 15. SUBJECT TERMS } \\
\text { Crater } \\
\text { Concrete } \\
\text { Rain and rainfall }\end{array}$} & \multicolumn{2}{|l|}{$\begin{array}{l}\text { ADR } \\
\text { Grooved pavement } \\
\text { Smooth pavement } \\
\text { Runoff }\end{array}$} & \multicolumn{2}{|c|}{$\begin{array}{l}\text { Runways (Aeronautics) - Maintenance and } \\
\text { repair } \\
\text { Blast effect }\end{array}$} \\
\hline \multicolumn{3}{|c|}{ 16. SECURITY CLASSIFICATION OF: } & $\begin{array}{l}\text { 17. LIMITATION } \\
\text { OF ABSTRACT }\end{array}$ & $\begin{array}{l}\text { 18. NUMBER } \\
\text { OF PAGES }\end{array}$ & $\begin{array}{l}\text { 19a. NAME OF RESPONSIBLE } \\
\text { PERSON }\end{array}$ \\
\hline $\begin{array}{l}\text { a. REPORT } \\
\text { UNCLASSIFIED }\end{array}$ & $\begin{array}{l}\text { b. ABSTRACT } \\
\text { UNCLASSIFIED }\end{array}$ & $\begin{array}{l}\text { c. THIS PAGE } \\
\text { UNCLASSIFIED }\end{array}$ & & 65 & $\begin{array}{l}\text { 19b. TELEPHONE NUMBER (include } \\
\text { area code) }\end{array}$ \\
\hline
\end{tabular}

